\title{
INTERMEDIATE HOSTS OF SCHISTOSOMA
}

\author{
African Biomphalaria and Bulinus : II *
}

\author{
G. MANDAHL-BARTH \\ Danmarks Akvarium, Charlottenlund, Denmark
}

SYNOPSIS

This study is an attempt to classify all described species of African Bulinus. It is based upon the author's examination of a great number of specimens collected from many parts of Africa. The variations attributable to age, environment and genetic factors which may be noted in the taxonomic characters are discussed, and some new species and subspecies are established. For each recognized species and subspecies the author states the distinguishing characters, indicates the geographical distribution, and gives a list of synonyms.

\section{The Genus Bulinus Müller}

To this genus belong most of the African freshwater pulmonates with a sinistral shell that is higher than it is wide. The only other genus possessing a similar shell is Physa Draparnaud, which, however, is easily distinguished from Bulinus by the lack of a pseudobranch and by the V-shaped arrangement of the transverse rows of radula teeth.

\section{Shell}

The shell is sinistral, invariably having a greater height than width, inversely conical, ovate or higher to almost cylindrical, and turreted according to the height of the spire. The height varies between $4 \mathrm{~mm}$ and $23 \mathrm{~mm}$. The number of whorls is usually from four to five, but in some forms it may be as great as seven. In most forms the whorls are evenly rounded, but in some an obtuse angle is present on the upper side. The aperture is high and wide in forms with a low spire, and relatively narrower in forms with a high spire. The outer lip is usually evenly rounded according to the shape of the last whorl, and has a sharp edge. The columellar margin is expanded and reflexed and either completely adnated to the penultimate whorl or leaves a narrow umbilical slit open. In some forms the columellar margin is straight, in others it is more or less twisted, and in the subgenus Physopsis it is truncate.

\footnotetext{
- This is the final part of a study on the known and suspect African snail intermediate hosts of Schistosoma; the first part (dealing with the genus Biomphalaria) was published in Bull. Wld Hlth Org., 1957, 16, 1103
} 
In colour the shell varies from almost pure white to dark chestnut brown, but usually it is a lighter or darker brown: the colour is often concealed by a greyish or black coating. The sculpture of the shell consists of transversely arranged growth lines, but some forms show more or less pronounced transverse ribs, which are usually best developed on the earlier whorls. A spiral sculpture consisting of delicate lines or nodules may be present in some forms, especially on the upper half of the shell.

The dimensions of the shell are stated according to the method described in the first part of this study. ${ }^{a}$ The width or diameter of the shell is the greatest dimension taken at a right angle to the axis. The height of the aperture is taken parallel to the axis.

\section{Soft anatomy ${ }^{b}$}

The general anatomical structure of Bulinus is very similar to that of Biomphalaria, and there is no reason to give a detailed description of the organs, which differ only insignificantly from those of Biomphalaria.

The pallial organs (see Fig. $1^{c}$ ) do not differ from those of Biomphalaria except for the shape of the pseudobranch. However, the development of the ridges seems to be of use as a systematic character and deserves a more detailed description. In all forms of Bulinus the ridge along the rectum and the ridge between the rectum and the kidney are present. The latter ridge in some forms (Physopsis and the high-spired Bulinus s.s.) is usually as long as the kidney, while it is much shorter in the low-spired Bulinus s.s. In Physopsis the renal ridge is nearly always present, while Bulinus s.s. lacks such a ridge, apart from very rare exceptions.

The digestive organs. In these organs differences have been found only in the radula; the general arrangement and development of the teeth are exactly the same as those of Biomphalaria. In most forms the endocones of the marginal teeth are divided into four to six small cusps, but unfortunately the division of both the lateral and the marginal endocones and ectocones is subject to great individual variation and has very little systematic value. A very great number of radulae have been examined in the hope of finding useful systematic characters, but without much success, because the individual variation within most forms shows a wider range than the differences between the various forms. The most reliable characters seem to be the size of the teeth and, in some cases, also the shape of the first lateral teeth (see Fig. 2).

The genital organs. These (see Fig. 3-5) differ from those of Biomphalaria mainly in the following features. The ovotestis consists of a smaller number

a See Bull. Wld Hlth Org. (1957) 16, 1103

$b$ The anatomy of some Bulinus is described more or less fully by Watson in Connolly, ${ }^{1}$ by Larambergue ${ }^{*}$ and by Hubendick.

$c$ All drawings were prepared with the aid of a camera lucida. 
Fig. 1. PALLIAL ORgans OF THREE SPECIES OF BULINUS
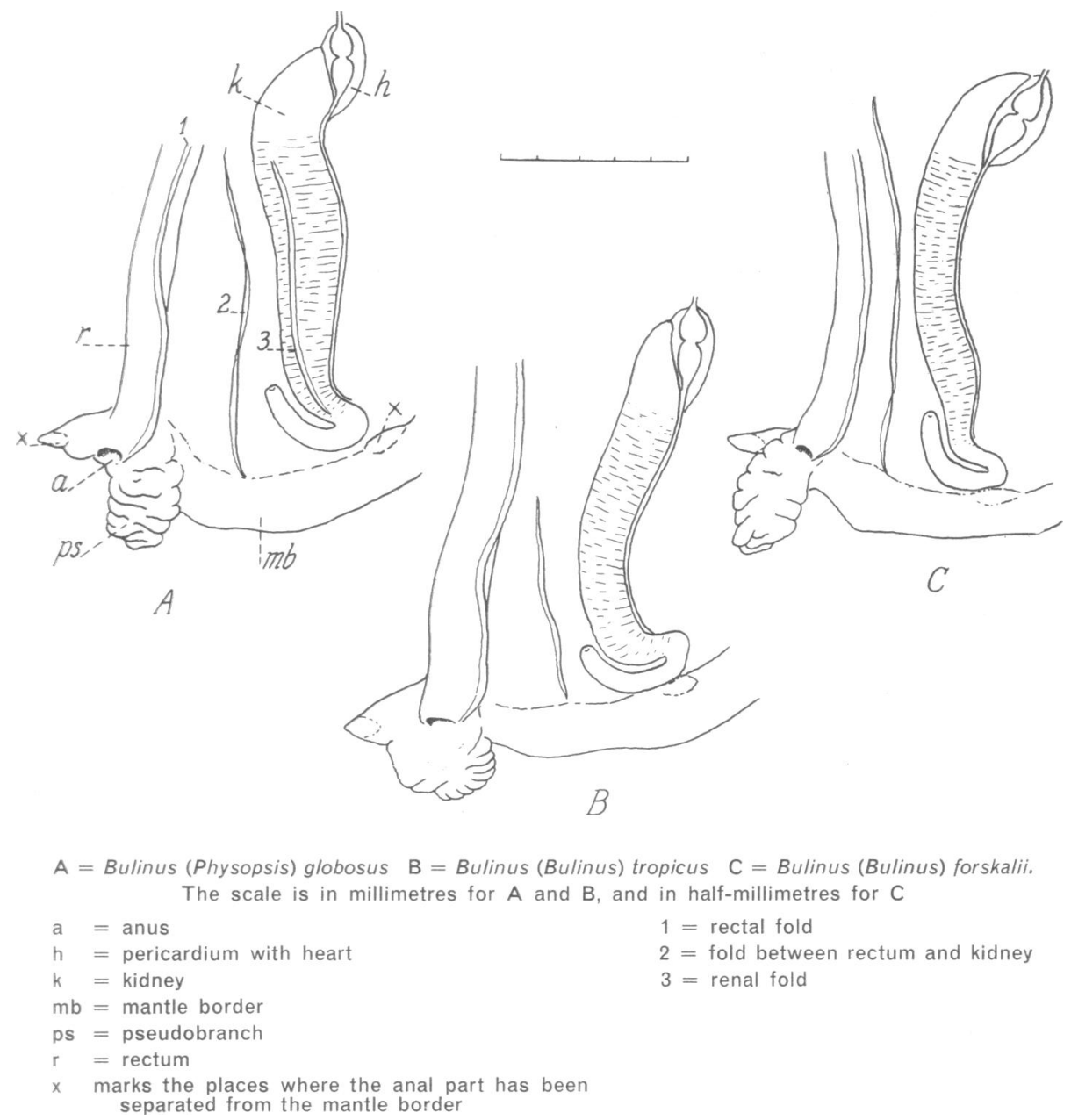

of follicles, the prostate gland forms a more compact organ because the tubes are arranged in the form of a fan, and the copulatory organ (" ultrapenis") is completely introverted when not in use. The last character is the most important, since an ovotestis and prostate gland of the same type as in Bulinus are found in several planorbid genera, while the "ultrapenis" is not known among planorbid genera other than Bulinus and the related Indoplanorbis Annandale and Prashad.

The copulatory organ consists, as in Biomphalaria, of a preputium and a vergic sheath surrounding the verge. The preputium is long and cylindrical, and on its inner surface is provided with two longitudinal muscular ridges 
FIG. 2. CENTRAL TOOTH AND FIRST LATERAL TOOTH OF SPECIES OF BULINUS

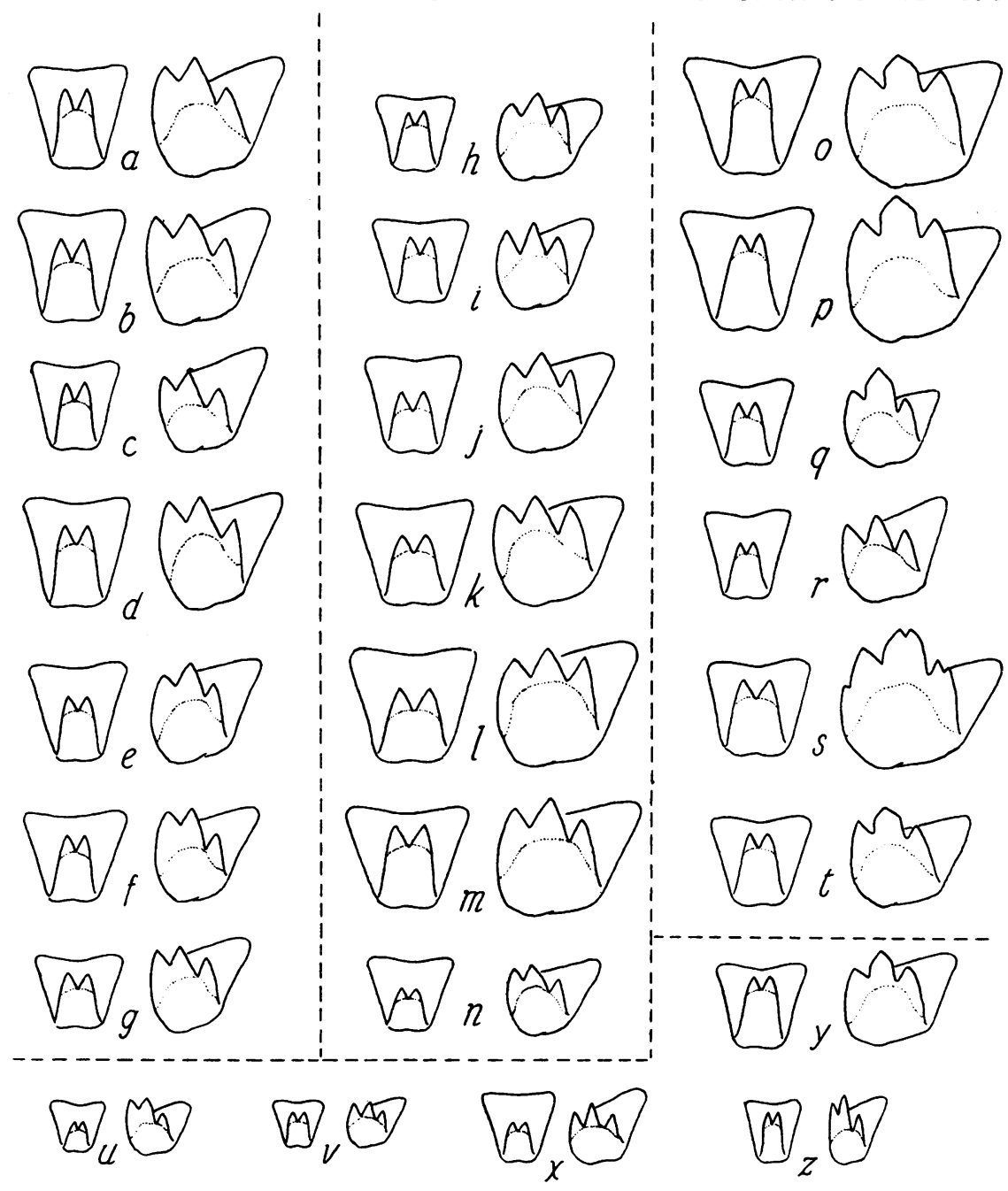

$0.01 \mathrm{~mm}$

Africanus (= Physopsis) group

$\mathrm{a}=\mathrm{B}$. africanus africanus, Durban

$\mathrm{b}=B$. africanus ovoideus, Arua, West Nile

c $=$ B. abyssinicus, Moico, Somalia

d $=$ B. nasutus, Bugondo, Uganda

e $=$ B. globosus, Sassa River, Angola

$f=B$. ugandae, Jinja Bay, Uganda

$\mathbf{g}=$ B. jousseaumei, Gambia

Tropicus group

h $=$ B. tropicus tropicus, Chozi River,

Northern Rhodesia

$i=B$. tropicus zanzebaricus, Lake Jipe

$\mathrm{j}=\mathrm{B}$. tropicus mutandaensis, Lake Rugwero, Ruanda

$k=B$. tropicus alluaudi, Ravine, Kenya

$\boldsymbol{l}=\boldsymbol{B}$. liratus, Ambositra, Madagascar

$m=B$. sericinus, Lake Gandu, Belgian Congo

$\mathrm{n}=$ B. guernei, Gambia
Truncatus group

$0=B$. truncatus truncatus, Cairo

$p=B$. truncatus trigonus, Entebbe, Uganda

$\mathbf{q}=\mathbf{B}$. transversalis, Bukasa Bay, Lake

$r=$ B. coulboisi, Butiaba, Lake Albert

$\mathbf{s}=\mathbf{B}$. nyassanus, Nkata Bay, Lake Nyasa

$\mathbf{s}=$ B. nyassanus, Nkata Bay, Lake Nyasa
$\mathrm{t}=\mathrm{B}$. truncatus rohlfsi, British Cameroons

Forskalii group

$\mathbf{u}=\boldsymbol{B}$. reticulatus, Kisumu, Kenya

$v=B$. camerunensis, British Cameroons

$\mathrm{x}=\mathrm{B}$. forskalii, Mkorani River, Tanganyika

$y=B$. senegalensis, Gambia

$\mathrm{z}=\mathrm{B}$. cernicus, Mauritius 
Fig. 3. GENITAL ORGANS OF B. GLOBOSUS, ANGOLA

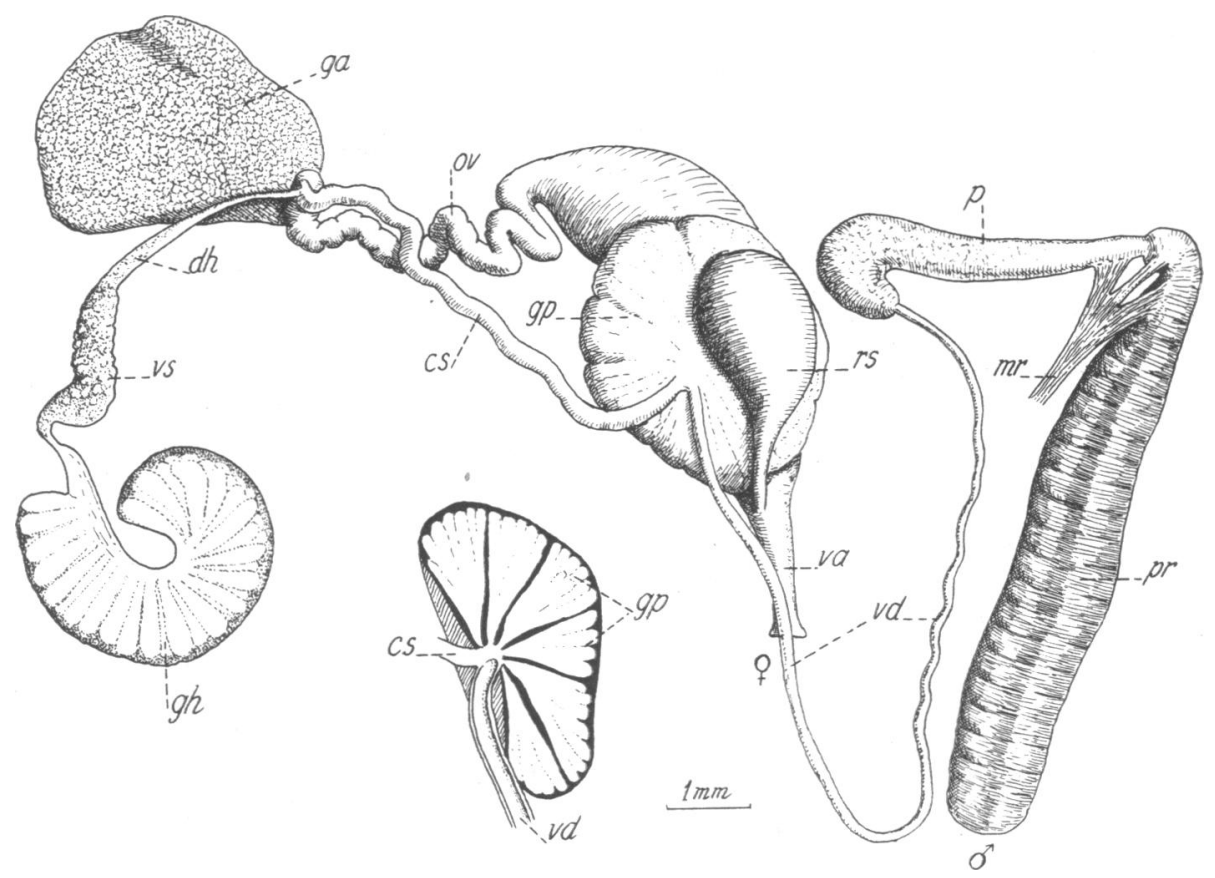

The small figure is taken in section through the prostate gland to show the arrangement of the tubes.

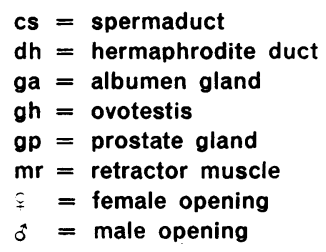$$
\text { ov = oviduct }
$$$$
\mathrm{p}=\text { vergic sheath }
$$$$
\text { pr }=\text { preputium }
$$$$
\text { rs }=\text { receptaculum seminis }
$$$$
\text { va }=\text { vagina }
$$$$
\text { vd }=\text { vas deferens }
$$$$
\text { vs }=\text { vesiculae seminales }
$$

or pilasters. The vergic sheath contains in its upper part a long, narrow, winding tube, the epiphallus, which corresponds to the continuation of the vas deferens running inside the verge of Biomphalaria. Next comes a more voluminous and folded section, usually provided with small papillae on the inner wall. This is the verge proper and it is completely homologous with the verge of Biomphalaria. When it is in use, it is everted and forms a long, club-shaped organ with a papillous surface. The lower section of the introverted organ is a narrow, cylindrical tube, which is homologous with the innermost layer of the vergic sheath of Biomphalaria. The wall of the sheath around this section is muscular and usually of a silky texture; it corresponds to the outer layer of the vergic sheath of Biomphalaria. At the junction with the preputium these two layers are still coalescent. 
FIG. 4. GENITAL ORGANS OF B. TROPICUS, SOUTHERN RHODESIA

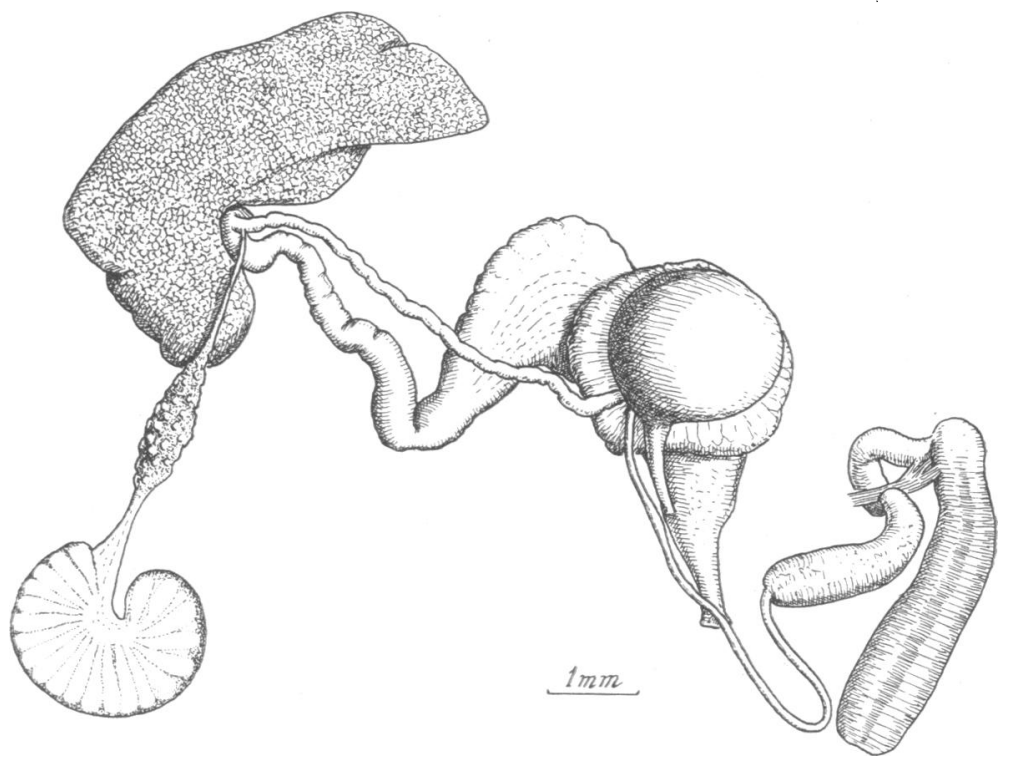

Fig. 5. genital organs of B. senegalensis, gambia

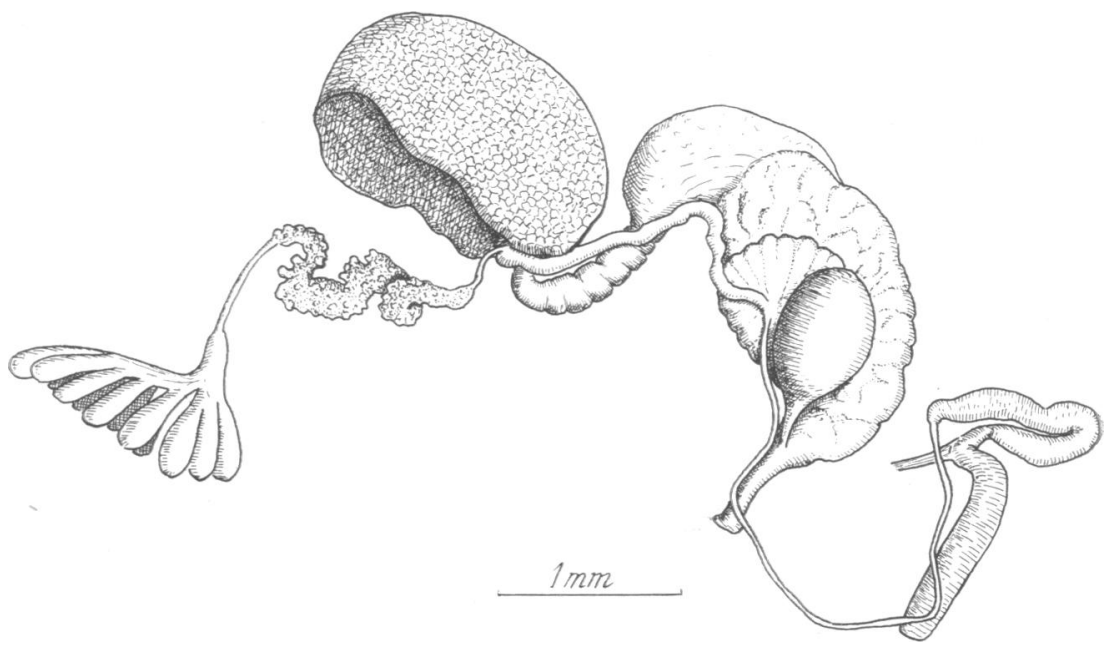


Fig. 6. DEVELOPMENT OF THE " ULtRAPENIS"

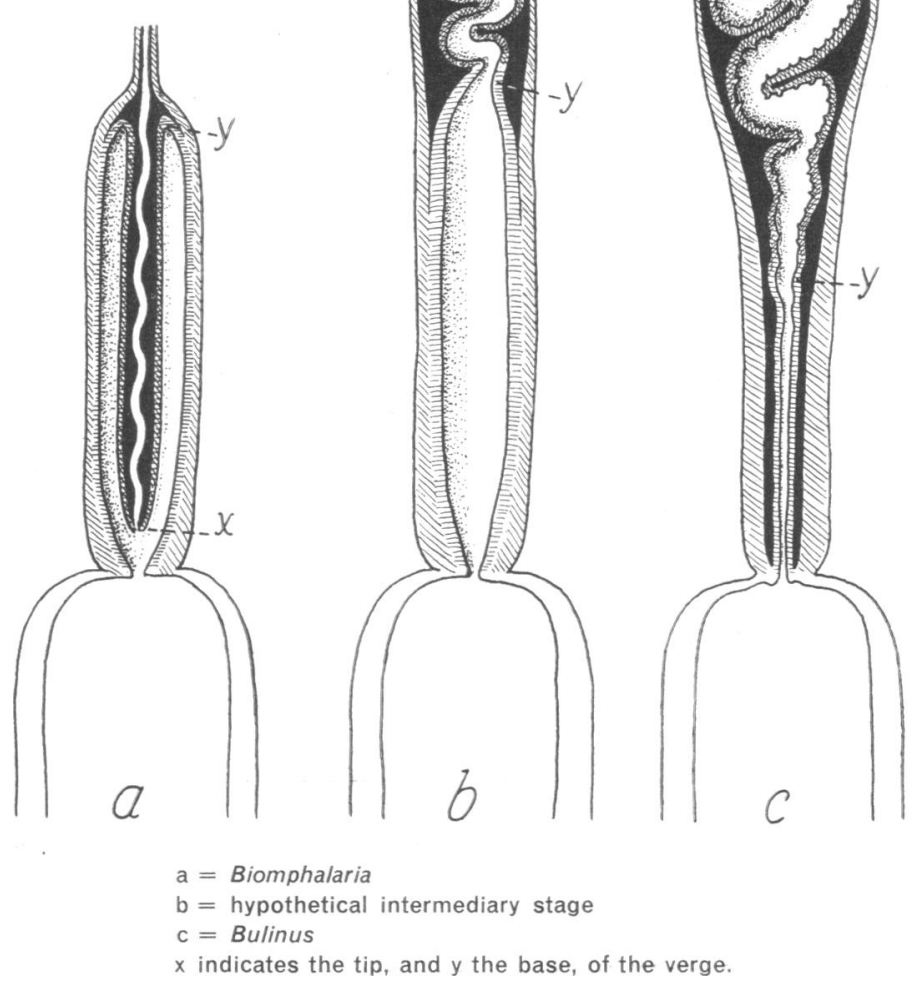

Fig. 6 (a-c) shows the probable evolution of the copulatory organ from the Biomphalaria type to the Bulinus type. The hypothetical intermediary stage (shown in Fig. 6 (b)) seems to be the only possible intermediary stage in which the copulatory organ could function, although the eversion of the verge would be somewhat difficult. It is presumably for this reason that the split between the two layers of the sheath has penetrated so close to the preputium, and that the lower part of the sheath has evolved the strong musculature. The eversion seems to start from the base, probably by a contraction of the muscular part of the sheath, and it is very likely that the blood pressure does not increase before most of the verge is everted.

The retractor muscle is attached both to the top of the preputium and to the lower part of the vergic sheath. 
In some specimens the entire penial complex remains undeveloped; such individuals are termed aphallic, and are frequently met with in certain forms of the truncatus group, although they are unknown in the groups of tropicus $^{a}$ and forskalii. In the subgenus Physopsis aphallic specimens are found, but they seem to be very rare.

\section{Species and Subspecies of Bulinus}

In all, more than one hundred species and a number of varieties of Bulinus s.s. have been described from Africa and from some of the African islands. Only about twenty of these are recognized here as valid species, and less than ten as subspecies. However, the species discrimination within Bulinus is extremely difficult, and it is almost inevitable that further studies will change the number of acknowledged species and subspecies.

The reasons for this unsatisfactory situation are mainly that examination of the soft anatomy of the various forms has not provided as good a basis for classification as was hoped. In this respect the internal organs seem to be of even less use than in Biomphalaria. In all examined forms the variability of the various organs is greater than the differences between related forms, and very few, if any, clear-cut species seem to exist within the genus. On the other hand, in several localities different forms have been found living together without interbreeding, and hence they must be regarded as different species. In other localities specimens may be found which display some characters corresponding to one species of Bulinus and others corresponding to another. This makes species discrimination very difficult and sometimes almost impossible. Even the commonly accepted division of Bulinus into two subgenera, Physopsis and Bulinus s.s., is not quite clear-cut. The distinguishing characters are the truncate columella and the ridge on the ventral surface of the kidney of Physopsis, which are not present in Bulinus s.s.; but sometimes Physopsis lacks the renal ridge or the truncation, and in very rare cases a renal ridge has been observed in Bulinus s.s. A third distinguishing character may be mentioned-the sculpture of the shell. Physopsis has, as a rule, a distinct sculpture consisting of spirally arranged rows of small impressions-a type of sculpture never found in Bulinus s.s.; there are, however, a few forms of Physopsis which deviate from this rule, one ( $B$. ugandae) having no particular sculpture at all, and another (a certain form of $B$. globosus) having ribbed first whorls, as is common in Bulinus s.s. Since, however, the two subgenera are in most cases easily distinguishable, it seems justifiable to maintain them.

The third commonly accepted subgenus, Pyrgophysa, can no longer be recognized, first, because no distinguishing characters exist and the classi-

a A few aphallic specimens of B. t. tropicus have been found in Southern Rhodesia. 
fication is therefore superfluous, and second, because $B$. forskalii, the typespecies of Pyrgophysa, has been shown to be closely related to the longspired B. senegalensis, the type-species of Bulinus. According to the International Rules of Nomenclature, Bulinus would be the proper name for the long-spired forms, so that if it were justifiable to separate the short-spired and the long-spired forms into two subgenera, it would be necessary to apply another name to the group hitherto known as Bulinus s.s.

The recognized species and subspecies may be divided into four groups according to the shape and sculpture of the shell and to some anatomical structures.

(1) Africana group (=subgenus Physopsis Krauss, 1848). The full-grown shell is between $10 \mathrm{~mm}$ and $23 \mathrm{~mm}$ high, the average size being about $15 \mathrm{~mm}$. The columella is usually truncate below and very often provided with a lamella. In most forms a characteristic sculpture, consisting of spirally arranged rows of small transverse impressions or nodules, may be visible on the upper part of the shell at a magnification of about $25 \times$. This sculpture has not been found in any of the forms belonging to the other groups. The ventral surface of the kidney usually possesses a distinct ridge.

From a medical point of view this is the most important group, as most of the forms commonly act as intermediate host of $S$. haematobium in Africa south of the Sahara.

(2) Tropicus group. This and the two following groups belong to the subgenus Bulinus s.s. The shell is usually of a rather dark brownish horncolour, and contains a strongly pigmented animal. The height of the fullgrown shell varies between $7 \mathrm{~mm}$ and $17 \mathrm{~mm}$. The columella is straight or somewhat twisted. In most forms, the first whorls are distinctly costulate, but in some they are without any particular sculpture, and in others the whole of the shell is ribbed. The ventral surface of the kidney has no ridge except in very rare cases. The copulatory organ is almost always present. The cusps on the lateral teeth are simply triangular.

This group is widely distributed in Africa south of the Sahara and is also represented in Madagascar. It is mainly found in smaller lakes and streams, and it has no representatives in the great lakes. Members of this group do not usually act as intermediate hosts of S. haematobium.

(3) Truncatus group. The shell is, as a rule, of a light yellowish colour, and the animal itself is whitish or greyish, usually with black spots on the mantle. The full-grown shell of most forms is about $10 \mathrm{~mm}$ high, but the Egyptian B. truncatus can grow to a size of almost $20 \mathrm{~mm}$. The columella is normally straight, but sometimes slightly twisted. In most forms the first whorls show no particular sculpture, but in some a more or less marked costulation may be present. No ridge on the ventral surface of the kidney has ever been found in this group. Aphallic specimens are common-in some 
forms much more common than individuals with a developed copulatory organ. In most forms the lateral teeth have broad arrowhead-shaped mesocones. This group is distributed from the Mediterranean countries and southward to the great lakes. In tropical Africa it is mainly represented in the greater lakes and rivers. Since B. truncatus acts as intermediate host of $S$. haematobium in Egypt, it is not excluded that other forms may also transmit bilharziasis in other parts of Africa, but nothing is known with certainty.

(4) Forskalii group (formerly known as Pyrgophysa). This group comprises the forms with a long and usually slender spire, which is at least as long as the aperture and very often distinctly longer. The colour of the shell is, as a rule, very pale, often quite hyaline or white, more rarely brownish. The colour of the animal varies from pure white to almost black. The columella is normally twisted. A more or less marked costulation, especially on the earlier whorls, is common, but some forms show no particular sculpture. A delicate spiral sculpture may also be present. The kidney has no ridge, and aphallic specimens have never been observed.

The group of forskalii is widely distributed all over Africa south of the Sahara, and is common also in Egypt, Mauritius and Madagascar. It is to be found mainly in very small ponds and ditches in quite shallow water. Some forms belonging to this group are transmitters of urinary bilharziasis.

As is always the case when genera with a difficult species discrimination are concerned, it is of the utmost interest to see which forms may be found living together without interbreeding, because such forms must be regarded as distinct species. Forms belonging to the africana group are frequently found in mixed populations with forms belonging to the truncatus or the tropicus group, and sometimes a member of the forskalii group occurs in the same habitat. Forms belonging to the truncatus group and the tropicus group have never been found in a mixed population, but this is probably rather a question of preference for different habitats than of close relationship.

Forms belonging to the same group are sometimes found in mixed populations with no sign of interbreeding-for example, africanus and globosus; nasutus and ugandae; transversalis and trigonus; reticulatus, forskalii and scalaris. It is desirable that field workers in Africa record such cases.

Our present knowledge of the influence of the environment upon the shape, size and sculpture of the shell is far from being sufficient to make it certain that none of the species and subspecies accepted here is not a mere ecophenotype. It is therefore very important that experiments on the influence of environment are carried out in various parts of Africa.

The following list shows the classification adopted: 
Africanus group (= Physopsis)

B. africanus africanus (Krauss)

B. africanus ovoideus (Bourguignat)

B. abyssinicus (Martens)

B. nasutus (Martens)

B. ugandae (Mandahl-Barth)

B. globosus (Morelet)

B. jousseaumei (Dautzenberg)

Tropicus group

B. tropicus tropicus (Krauss)

B. tropicus angolensis (Morelet)

B. tropicus zanzebaricus (Clessin)

B. tropicus mutandaensis (Preston)

B. tropicus alluaudi (Dautzenberg)

B. liratus (Tristram)

B. sericinus (Jickeli)

B. guernei (Dautzenberg)
Truncatus group
B. transversalis (Martens)
B. truncatus truncatus (Audouin)
B. truncatus trigonus (Martens)
B. truncatus rohlfsi (Clessin)
B. coulboisi (Bourguignat)
B. nyassanus (Smith)

\section{Forskalii group}
B. camerunensis $\mathrm{n}$. $\mathrm{sp}$.
B. reticulatus Mandahl-Barth
B. cernicus (Morelet)
B. forskalii (Ehrenberg)
B. scalaris (Dunker)
$B$. senegalensis Müller

The africanus group (= subgenus Physopsis)
(1) B. (Ph.) africanus africanus (Krauss) (see Plate I)

1848. Physopsis africanus Krauss. Krauss, Die südafrikanischen Mollusken, Stuttgart, p. 85, plate 5, fig. 14. Type-locality : Port Natal (Durban).

1913. Physopsis rekwaensis Preston. Rev. zool. afr. 3, p. 55-56, plate 5, fig. 11. Typelocality : Lake Rukwa, Tanganyika.

The shell is of medium size or larger, consisting of about four evenly rounded whorls regularly and rather rapidly increasing in size, and separated by usually shallow sutures. The spire is typically rather low, but sometimes higher, in which case the sutures are deeper. The aperture is ovate and rather large, with an evenly curved outer lip and a short columellar margin, usually distinctly truncate below. The truncation is strengthened by a usually strong white lamella. The outward reflexion of the columella either completely conceals the umbilicus or leaves a narrow slit open. The sculpture on the upper part of the shell consists of spirally arranged, rather coarse, transverse impressions; on the lower part no particular sculpture is present. The colour varies from a light yellow to a somewhat dark brownish horn, and the surface of the shell is rather glossy.

The mean measurements of ten specimens from Durban are as follows: height of shell $(\mathrm{H}): 14.5 \mathrm{~mm}$; diameter of shell (D): $10.8 \mathrm{~mm}$; and height of aperture (A): $11.0 \mathrm{~mm}$. The biggest specimen (from Namwala, Northern Rhodesia) has the following measurements $-\mathrm{H}: 19.1 \mathrm{~mm}$; D: $13.6 \mathrm{~mm}$; and A: $14.6 \mathrm{~mm}$.

In the copulatory organ the vergic sheath is distinctly longer and broader than the preputium (see Fig. 7 (a)). 
FIG. 7. TYPICAL PROPORTIONS OF COPULATORY ORGAN IN FOUR SPECIES OF BULINUS (PHYSOPSIS)
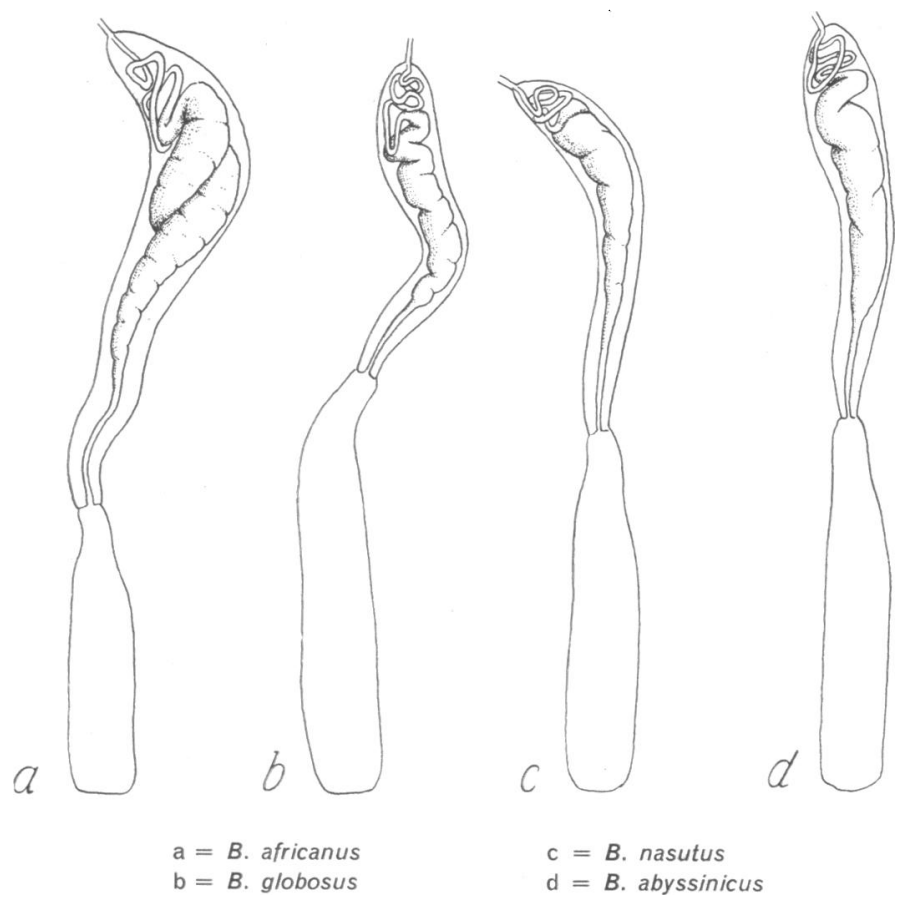

Distribution: Natal, Transvaal, Southern and Northern Rhodesia, and probably also Mozambique and southern Tanganyika.

It is extremely difficult on shell characters alone to distinguish $B$. africanus from $B$. globosus, but the differences in structure of the copulatory organs seem to be a fairly reliable determining character. The shell characters, that is, the sculpture and the columella, are not so constant.

In the Salisbury area in Southern Rhodesia a curious form (see Plate I, Fig. 1 (b)) with a rather high spire and an almost white shell was found in the same habitat as B. globosus, and no intermediates, neither in shell nor in the structure of the copulatory organ, were discovered. On the Kafue Flats in Northern Rhodesia a remarkable local form (see Plate I, Fig. 1 (c)) is prevalent, closely resembling the Nyasa form of B. globosus (= "Physopsis karongensis" Smith). No specimens from Lake Rukwa have been available for examination, but Preston's description and figure of "Physopsis rekwaensis" suggest that it does not differ essentially from the typical B. africanus.

Material examined : Natal : Durban. Transvaal : Johannesburg. Southern Rhodesia : Salisbury. Northern Rhodesia : Namwala, Kafue River, Lusaka, Fort Jameson. 
(2) B. (Ph.) africanus ovoideus (Bourguignat) (see Plates II, III)

1879. Physopsis ovoidea Bourguignat. Bourguignat, J. R., Description de diverses espèces terrestres et fluviatiles et de différents genres de mollusques de l'Egypte, de l'Abyssinie, de Zanzibar, du Sénégal, et du centre de l'Afrique, Paris, p. 16. Type-locality : Kyngani River, near Bagamoyo, Tanganyika.

1897. Physopsis tanganyicae Martens. Martens, Beschalte Weichtiere Deutsche OstAfrikas, Berlin, p. 144. plate 6, fig. 12. Type-locality : Lake Tanganyika.

This subspecies differs from the nominate race by the usually bigger, coarser, and less glossy shell.

The mean measurements of ten shells from Arua, West Nile, are as follows- $-\mathrm{H}: 17.2 \mathrm{~mm}$; D: $11.2 \mathrm{~mm}$; A: $12.5 \mathrm{~mm}$. The biggest specimen measured-H:19.6 mm; D: $12.4 \mathrm{~mm}$; and A: $14.3 \mathrm{~mm}$.

The copulatory organ has the same proportions as in the nominate race.

Distribution: eastern Africa from Tanganyika to the Sudan.

It is possible that the form here called ovoideus is not identical with Bourguignat's ovoideus, for which no illustration exists. Certainly, Germain, ${ }^{4}$ (p. 503, plate 5, fig. 4) claims to illustrate the type, but it is doubtful whether he is correct. The supposed type-specimen does not fit very well into Bourguignat's description, and is further stated to come from Kondoa, about $360 \mathrm{~km}$ west of Bagamoyo. Unfortunately, no specimen from Kyngani River at Bagamoyo (or from Kondoa) has been available for examination. If in the future it becomes evident that ovoideus in the sense adopted here does not occur in Kyngani River, it will be preferable to name the subspecies $B$. africanus tanganyicae (Martens), since there is no observable difference between the Tanganyika form and the form from Uganda and Kenya.

Material examined: Tanganyika Territory: Pangani. Kenya Colony: Kitui, Kasat River, Asembo. Uganda : Laufori, Arua, Lira, Kidatok Dam, Gulu. Belgian Congo : Albertville, Kabare, Nyakabera River.

\section{(3) B. (Ph.) abyssinicus (Martens) \\ (see Plate IV, Fig. 3 (a))}

1866. Physa (Physopsis) abyssinica Martens. Malakozool. Bl. 13, 100. Type-locality: southern Ethiopia.

1879. Physopsis eximia Bourguignat. Bourguignat, J. R., Description de diverses espèces terrestres et fluviatiles et de différents genres de mollusques de l'Egypte, de l'Abyssinie, de Zanzibar, du Sénégal et du centre de l'Afrique, Paris, p. 13. Type-locality : southern Ethiopia.

1885. Physopsis meneliki Bourguignat. Bourguignat, J. R., Mollusques terrestres et fluviatiles recueillis par M. Paul Soleillet dans son voyage au Choa (Ethiopie meridionale), Paris, p. 25. Type-locality : Hauash River.

1885. Physopsis soleilleti Bourguignat. Bourguignat, J. R., Mollusques terrestres et fluviatiles recueillis par M. Paul Soleillet dans son voyage au Choa (Ethiopie meridionale), Paris, p. 25, plate 1, fig. 11. Type-locality : Lake Haussa, Ethiopia. 
The shell is of medium size, consisting of nearly five rather convex and somewhat shouldered whorls, separated by rather deep sutures. The sculpture on the upper part of the shell is a fine corrugation rather than a spiral sculpture. The colour of the shell ranges from very light yellowishgrey to almost white.

The mean measurements of nine specimens from Moico, Somalia, are as follows- $\mathrm{H}$ : $13.4 \mathrm{~mm}$; $\mathrm{D}: 9.2 \mathrm{~mm}$; and A: $9.4 \mathrm{~mm}$. The biggest shell measures-H: $17.6 \mathrm{~mm}$; D: $10.7 \mathrm{~mm}$; and A:12.8 mm.

The radula teeth are somewhat smaller than those of $B$. africanus. In the copulatory organ the vergic sheath is equal in length and width to the preputium (see Fig. 7 (d)), and is very similar to that of $B$. nasutus.

Distribution: southern Ethiopia, Somalia, and probably also British Somaliland.

B. abyssinicus is easily recognized by its light-coloured shell with shouldered whorls. The three species described by Bourguignat differ from B. abyssinicus mainly in the length of the spire-a character which is not very reliable where freshwater snails are concerned.

Material examined: Somalia: Webi Shebeli, Moico, Giuba, Mogadiscio.

(4) B. (Ph.) nasutus (Martens)

(see . Plate IV, Fig. 3 (b, c))

1879. Physopsis nasuta Martens. S. B. Ges. naturf. Fr. Berl. p. 102. Type-locality : Bagamoyo, Tanganyika.

1879. Physopsis praeclara Bourguignat. Bourguignat, J. R., Description de diverses espèces terrestres et fluviatiles et de différents genres de mollusques de l'Egypte, de l'Abyssinie, de Zanzibar, du Sénégal et du centre de l'Afrique, Paris, p. 14. Type-locality: Kyngani River at Bagamoyo.

The full-grown shell has five-and-a-half regularly increasing whorls, which means at least half a whorl more than any other Physopsis has. The spire is equal in length to the aperture or a little shorter, forming a broad cone. It is characteristic of this species that the basal margin of the aperture is groove-like and more or less drawn out in the shape of a short spout. The columella is straight or twisted and only slightly truncate. The sculpture on the spire consists of spirally arranged rows of minute nodules. The colour is usually a yellowish or reddish brown. At each pause in the growth the outer lip becomes slightly thickened by a reddish brown lip, and in many specimens two or more such lips may be seen inside as darker, and outside as lighter, transverse bands.

The mean measurements of ten shells from Bugondo, Uganda, are as follows- $\mathrm{H}: 17.6 \mathrm{~mm}$; $\mathrm{D}: 9.6 \mathrm{~mm}$; and A: $9.8 \mathrm{~mm}$. The biggest specimen (from Asembo, Kenya) has the following dimensions-H: $21.1 \mathrm{~mm}$; D: $10.7 \mathrm{~mm}$; and $\mathrm{A}: 10.7 \mathrm{~mm}$. 
The radula teeth are equal in size to those of $B$. africanus. The vergic sheath is as long as, or a little longer than, the preputium (see Fig. 7 (c)).

Distribution: northern Tanganyika, Kenya, and Uganda.

It is extremely difficult to separate the shorter-spired specimens of nasutus from long-spired globosus, and in the north-eastern part of Tanganyika they seem to merge into each other, but, unfortunately, only empty shells have been available from this area. Judging from the situation in Tanganyika, it would be most reasonable to regard nasutus as being conspecific with globosus, but elsewhere the two forms behave more like different species. More material from Tanganyika must be examined before a final decision can be made.

Bourguignat's Physopsis praeclara is certainly a synonym for $B$. nasutus. Both were described in 1879 and it has been impossible to determine which of them has priority. Since, however, B. nasutus is the most commonly known, it seems better to accord it priority.

Material examined: Tanganyika Territory: Magu, Tinde, Mwanza. Kenya Colony: Kitui, Asembo. Uganda: Iganga, Bugungu, Nyenga, Nkondo Dam, Bugondo, Akoli.

(5) B. (Ph.) ugandae (Mandahl-Barth)

(see Plate IV, Fig. 3 (d), and Plate V)

1954. Bulinus (Physopsis) globosus ugandae Mandahl-Barth. Ann. mus. Congo Belge, $8 v o, 32,114$, fig. $55 a-h$. Type-locality: Jinja Bay, Lake Victoria.

The shell is usually of a somewhat small size and of a dull, rather dark brown colour. It differs from the other Physopsis forms by the complete absence of spiral sculpture on the spire, the length of which varies considerably. The truncation of the columella is very slight and gives the shell much resemblance to some forms of the tropicus group.

The mean measurements of ten paratypes are as follows $-\mathrm{H}: 12.0 \mathrm{~mm}$; D: $8.8 \mathrm{~mm}$; and A: $8.1 \mathrm{~mm}$. The biggest specimen (from Bugondo) has the following measurements-H: $15.9 \mathrm{~mm}$; D: $10.9 \mathrm{~mm}$; and A: $10.0 \mathrm{~mm}$.

The radula teeth are smaller than those of $B$. africanus. The copulatory organ is of the same type as in $B$. globosus, with a vergic sheath which is distinctly shorter and narrower than the preputium.

Distribution: western Kenya and Uganda.

This species was originally described as a subspecies of $B$. globosus, but since Cridland ${ }^{2}$ has shown that it is not susceptible to $S$. haematobium while $B$. globosus is so to a very high degree, and since they are found together in some areas, it seems better to regard them as specifically different.

The curious Physopsis from Lake Mutanda in south-western Uganda is here referred to $B$. ugandae because of the absence of spiral sculpture. No specimens have been available for dissection. It is the only record of $B$. ugandae from this part of Uganda, where otherwise B. globosus is preva- 
lent. The Lake Mutanda form amazingly resembles the local form of B. tropicus; this conformity is obviously a result of local conditions.

From Kosti and Rumbek in the Sudan the author has examined specimens of a Physopsis which is very reminiscent of $B$. ugandae, but the shells are bigger, blunter, and of a light yellow colour (see Plate IV, Fig. 3 (d)). A similar form has been found near Namasagali at the outlet of the Victoria Nile into Lake Kyoga. This form is not identical with Physopsis didieri Rochebrune and Germain, described as being from Dufile near the boundary between Uganda and the Sudan. An examination of the type-specimen has shown that didieri is synonymous with $B$. globosus.

Material examined: Uganda: Jinja Bay, Napoleon Gulf, Victoria Nile, Bugondo, Masindi, Serere, Kibimba River, Kazinga Channel, Lake Mutanda. Tanganyika Territory : Ilemera. Kenya Colony : Kisumu. Sudan: Kosti, Rumbek.

\section{(6) B. (Ph.) globosus (Morelet)}

(see Plates VI, VII, VIII)

1866. Physa globosa Morelet. J. Conchyliol. 14, 162. Type-locality : Dande River, Angola.

1879. Physopsis stanleyana Bourguignat. Bourguignat, J. R., Description de diverses espèces terrestres et fluviatiles et de différents genres de mollusques de l'Egypte, de l'Abyssinie, de Zanzibar, du Sénégal et du centre de l'Afrique, Paris, p. 14. Type-locality: Kyngani River at Bagamoyo, Tanganyika.

1887. Physopsis leroyi Grandidier. Bull. Soc. Malacol. Fr. 4, 189. Type-locality: Usagara, Tanganyika.

1889. Physopsis bloyeti Bourguignat. Bourguignat, J. R., Mollusques de l'Afrique équatoriale, de Moguedouchoa à Bagamoyo et de Bagamoyo au Tanganika, Paris, p. 160. Type-locality: Kondoa, Tanganyika.

1893. Physa karongensis E. A. Smith. Proc. zool. Soc. Lond., p. 640, plate 59, fig. 15. Type-locality: Karonga, Lake Nyasa.

1904. Physopsis didieri Rochebrune and Germain. Bull. Mus. Hist. nat., Paris, 10, 142. Type-locality: Dufile, Uganda.

1907. Physopsis martensi Germain. Bull. Mus. Hist. nat., Paris, 13, $65=$ Physopsis ovoidea Martens (non Bourguignat). 1897, Martens, Beschalte Weichtiere Deutsch Ost-Afrikas, Berlin, p. 142, plate 6, fig. 13. Type-locality: Bukome, Lake Victoria.

1913. Physopsis choziensis Preston. Rev. zool. afr. 3, 55, plate 5, fig. 12. Type-locality: Chozi River, Northern Rhodesia.

1913. Physa masakaensis Preston. Rev. zool. afr. p. 57, plate 5, fig. 7. Type-locality: Masaka, Uganda.

The shell is of medium size or bigger, ovate, with an obtuse, generally only slightly prominent spire, and consisting of from four to four-and-ahalf rapidly increasing whorls separated by a rather shallow suture. The aperture has an evenly curved outer lip and a twisted or straight columella, which is more or less truncate below. The outward expanded part of the columella usually completely closes the umbilicus, but sometimes a narrow slit remains open. The first whorls, and sometimes also the upper part of the last whorl, show a more or less distinct spiral sculpture consisting of 
small transverse lines or impressions. The colour is a fighter or darker-in fresh shells usually glossy-brownish horn.

The mean measurements of 20 shells from Sassa River, Angola, are as follows-H: $15.5 \mathrm{~mm}$; D: $11.8 \mathrm{~mm}$; and A: $11.9 \mathrm{~mm}$. The biggest specimen (from Asembo, Kenya) measures-H: $22.5 \mathrm{~mm}$; D: 14.0; and A: $14.0 \mathrm{~mm}$.

The radula teeth are smaller than those of $B$. africanus. The copulatory organ has a vergic sheath distinctly shorter, and not wider, than the preputium (see Fig. 7 (b)).

Distribution: all Africa south of the Sahara.

B. globosus, the commonly accepted transmitter of urinary bilharziasis, has a very wide distribution and is found in different kinds of habitat, ranging from the greatest lakes to small ponds, and from big rivers to small ditches. It thus shows a wide range of variability, and indeed some of the variations may very probably turn out to be true geographical races. For the present it is hardly possible to distinguish between geographical races and mere ecophenotypes, as not enough is known of the influence of environment upon the size and shape of the shell. A number of the more remarkable local forms are described in the following paragraphs.

The typical form of globosus (see Plate VI, Fig. 5 (a)) is from Angola, but very similar shells can be found in most parts of Africa. However, in certain smaller areas quite distinct forms are prevalent, and some of them have been described as supposed new species.

In the Chozi River area in Northern Rhodesia a form of globosus occurs which has a peculiar transverse sculpture, usually a delicate costulation, which, in some specimens, becomes coarser towards the aperture, where it may take on the character of a malleation (see Plate VI, Fig. 5 (c, d)). This form was described by Preston as Ph. choziensis.

In Katanga a narrow, almost cylindrical form is common (see Plate VII, Fig. $5(\mathrm{~g})$ ). Curiously enough a very similar form is found in Liberia (see Plate VII, Fig. 5 (h)) and Nigeria. In the latter country also another form occurs (see Plate VIII, Fig. $5(\mathrm{k})$; it is characterized by the long spire and strong lamella on the truncated part.

In Zanzibar several forms occur, among them a very thin-shelled one, probably from a habitat poor in lime (see Plate VII, Fig. 5 (e)).

From Lake Ngwasi, Tanganyika, I have seen two specimens of a strange form, possibly a distinct species (see Plate VII, Fig. 5 (f)). The shell is very large (H: $19.0 \mathrm{~mm}$; D: $12.5 \mathrm{~mm}$; and A: $14.4 \mathrm{~mm})$ with a high and narrow aperture, and is of a glossy chestnut-brown colour. The first whorls have no spiral sculpture, but are distinctly costate, which is remarkable since such a sculpture is unknown in other forms of Physopsis. In the anatomy it does not differ from the typical globosus. More material is desirable.

Lake Nyasa is the type-locality for Smith's Ph. karongensis, a rather small form of globosus with a more solid shell than the typical form (see 
Plate VIII, Fig. 5(j)). It is very reminiscent of the form of B. africanus from the Kafue Flats in Northern Rhodesia.

In Uganda, west of Lake Victoria, a globosus form with a very thin columella showing only slight truncation is found; it is not, however, very common (see Plate VI, Fig. 5 (b)). It was described by Preston as Physa masakaensis and has hitherto been regarded as belonging to Bulinus s.s., but an examination of the type-specimen (in the Musée Royal du Congo Belge) showed clearly its proper position as a Physopsis. Specimens of a similar form from other parts of western Uganda have been dissected, and no differences from the typical globosus could be found.

Along the Congo River from Ponthierville to Stanleyville a rather small form, not exceeding $14 \mathrm{~mm}$ in height, with somewhat shouldered whorls and a more pointed spire, is common.

It will certainly be possible, when more material is available, to distinguish several other local forms; it must then be decided whether they are true subspecies or only ecophenotypes. This is a question of more than academic interest, since it has been proved that not all forms of Physopsis are vectors of urinary bilharziasis. In this connexion it must be remembered that $B$. ugandae shows no greater differences from the typical globosus than some of the local forms mentioned above.

Material examined: Transvaal: Kaapmuiden, Tzaneen, White River. Southern Rhodesia: Salisbury, Triangle Sugar Estate. Northern Rhodesia: Ndola, Zambesi, Mankoyo, Kafue, Mongu, Mazabuka, Lusaka, Mumbwa, Mwinilunga, Chibila, Lutale, Chozi River, Mankolo, Fort Jameson, Kasempa, Fort Roseberry, Libonda, Limpasa Dam. Mozambique : Boboli, Limpopo, Zambesi. Angola : Sassa River, Morine, Lufinda, Dando, Cangombe, Chibia. Tanganyika Territory : Nderema, Mwanza, Ngudu, Korogwe, Lake Nyasa, Lake Ngwasi. Kenya Colony: Mombasa. Thika Falls, Sukari Dam, Kisumu, Asembo, Kavirondo Gulf. Uganda : Ogama Dam, Lake Kikoronga, Bwamba, Kazinga Channel, Lake Edward. Belgian Congo: Usumbura, Muska, Albertville, N'kolo, Irumu, Mulongo, Faradje, Kongolo, Stanleyville, Kindu, Leopoldville, Ponthierville, Elisabethville, Swakibula. Nigeria: Male River, Kafo Plateau. Ghana: Wa to Kajo, the rivers Tono, Kyire Kyipua, Ankobra, Aboabo, and Ho. Liberia: Sanoquellie. Gambia : Jakoroh.

(7) B. (Ph.) jousseaumei (Dautzenberg)

(see Plate IX)

1890. Isidora jousseaumei Dautzenberg. Mém. Soc. zool. Fr. 3, 132, plate 1, fig. 10. Type-locality: Senegal River near Medine.

This is the smallest species of Physopsis. The shell rarely exceeds $10 \mathrm{~mm}$ in height; it consists of four whorls and generally has a very low spire. The columellar margin is very slightly truncate. The aperture is relatively larger than in other Physopsis and is almost as high as the shell (on average, $85 \%$ as against $75 \%$ in $B$. africanus and $72 \%$ in B. globosus). The spiral sculpture - when present-is extremely delicate. The colour is, as a rule, a rather dull brownish, but lighter, almost hyaline, shells occur. 
The mean measurements of ten shells from Simoto Bolon, Gambia, are as follows-H: $9.7 \mathrm{~mm}$; $\mathrm{D}: 7.9 \mathrm{~mm}$; and $\mathrm{A}: 8.5 \mathrm{~mm}$. The biggest specimen (from the Casamance River) has the following measurements:- $\mathrm{H}: 10.4 \mathrm{~mm}$; D: $8.0 \mathrm{~mm}$; and A: $8.6 \mathrm{~mm}$.

The radula teeth are smaller than in the other Physopsis. The copulatory organ is of the same proportions as those of B. globosus. Specimens with no renal ridge are common.

Distribution: Senegal, Gambia, and the French Sudan.

B. jousseaumei is in all respects intermediary between Physopsis and Bulinus s.s.

Material examined: Gambia: Gambissar, Simoto Bolon, Boro Kandakase. French West Africa : Firgoun, Casamance River.

The tropicus group

(8) B. (B.) tropicus tropicus (Krauss)

(see Plate X)

1841. Physa natalensis "Krauss" Küster. Martini \& Chemnitz, Systematisches Conchylien-Cabinet, Berlin, 2. Aufl., vol. I: 17, 8, plate 1, fig. 12-14. Type-locality: Natal.

1848. Physa diaphana Krauss. Krauss, Die südafrikanischen Mollusken, Stuttgart, p. 84, plate 5, fig. 11. Type-locality: Umgeni Valley, Natal.

1848. Physa tropica Krauss. Krauss, Die südafrikanischen Mollusken, Stuttgart, p. 84. plate 5, fig. 12. Type-locality: Lepenula River, Transvaal.

1856. Physa verreauxii Bourguignat. Rev. Mag. Zool. (2) 8, 237, plate 15, fig. 3-4. Type-locality: Olifants River, Transvaal.

1856. Physa cyrtonota Bourguignat. Rev. Mag. Zool. p. 238, plate 15, fig. 1-2. Typelocality: Olifants River, Transvaal.

1880. Physa lirata Craven. Proc. zool Soc. Lond. p. 617, plate 57, fig. 10. Type-locality: Mooi River, Transvaal (not Physa lirata Tristram).

1886. Physa craveni Ancey. Naturaliste, 8, 358 (new name for Ph. lirata Craven)

1889. Physa cornea Morelet. J. Conchyliol. 37, 16, plate 1, fig. 8. Type-locality: Port Elizabeth, Cape Province.

1903. Physa zuluensis Melvill \& Ponsonby. Ann. Mag. nat. Hist. (7), 12, 606, plate 32, fig. 4. Type-locality: eastern Zululand.

1903. Isidora compta Melvill \& Ponsonby. Ann. Mag. nat. Hist. (7), 12, 606, plate 32, fig. 14. Type-locality: Boksburg, Transvaal.

1936. Bulinus hemprichii depressus Haas. Abh. senckenb. naturf. Ges. No. 431, p. 28 , plate 1, fig. 15 (a-c). Type-locality: canal from the village Nsomo to Lake Bangweolo.

The typical form has a shell consisting of from four to four-and-a-half rather convex whorls separated by fairly deep sutures. The spire is rather high, about half the length of the aperture, and has a pointed apex. In the typical form the aperture is large, with a regularly curved outer margin, and a broadly reflexed columellar margin which is outwardly expanded over the narrow umbilicus. The sculpture consists of closely set, rather 
coarse growth lines, which sometimes, and especially on the first whorls, have the character of ribs. The colour is generally a lighter or darker dull brownish.

The mean measurements of 25 shells from Salisbury, Southern Rhodesia, are as follows-H: $12.8 \mathrm{~mm}$; D: $9.8 \mathrm{~mm}$, and A: $8.7 \mathrm{~mm}$. The biggest specimen (from Kapalonga Dam, Northern Rhodesia) has the following measurements-H: $15.2 \mathrm{~mm}$; D: $10.8 \mathrm{~mm}$; and A: $10.2 \mathrm{~mm}$.

The animal is usually dark-coloured. The radula teeth are rather small. The copulatory organ has the same shape and proportions as that of $B$. globosus. In a few cases a renal ridge has been observed.

Distribution: South Africa, Southern and Northern Rhodesia.

B. tropicus is not the oldest name for this species. "Physa" natalensis has seven years' priority, and "Physa" diaphana has page-priority. Natalensis differs from the typical form of tropicus by its less expanded and somewhat twisted columellar margin. It has been erroneously referred to Physopsis because of the twisted (but not truncate) columella. Shells with such a twisted columella are rather common in all subspecies of tropicus ; it apparently represents nothing more than an individual variation. If the rules of nomenclature were to be followed strictly, and the name B. tropicus to be replaced by $B$. natalensis, much confusion would be caused, and since $B$. tropicus has always been regarded as a distinct and easily recognizable species and $B$. natalensis as a doubtful one, it seems wiser to maintain $B$. tropicus as the proper name for this species. "Physa" diaphana has priority in so far as Krauss placed the description of it immediately before the description of tropicus. It is presumably only a dwarf form of tropicus, evolved under suboptimal conditions.

$B$. tropicus is a very variable species as regards both the size and the shape of the shell. The variations in shape are due mainly to the relative length of the spire, the convexity of the whorls, and the shape of the columella. Some of these variations have been described as species. "Physa" verreauxii is an abnormal shell with a much prolonged spire. "Physa" zuluensis has a very short spire and a twisted columella. Haas's depressus has a convolute shell with no spire at all; similar forms have been found in populations with more high-spired specimens. "Physa" cornea is either a dwarf form like diaphana or a rather immature shell. B. tropicus reaches maturity at a very young stage; in one population (Kapalonga Dam, Northern Rhodesia) most specimens were between $11 \mathrm{~mm}$ and $14 \mathrm{~mm}$ in height, but specimens of only $7 \mathrm{~mm}$ were apparently mature. The other listed synonyms differ only very little from the typical tropicus.

Material examined: Cape Province : Mossel, Goudini. Orange Free State : Bloemfontein, Westminster. Natal: Scottburgh, Durban, Mayfield, Umhlatuzana River, Umgeni River, Riverview Village. Transvaal : Kaapmuiden, Aapies River, Klein Lutaba, Hector's Spruit. Southern Rhodesia : Salisbury. Northern Rhodesia : Ndola, Mankoyo, Mazabuka, Lusaka, Chozi River, Nkinde, Fort Jameson, Chilambara Pan. 
(9) B. (B.) tropicus angolensis (Morelet) (see Plate XI)

1866. Physa angolensis Morelet. J. Conchyliol. 14, 162. Type-locality: Duque de Braganza, Angola.

1866. Physa welwitschi Morelet. J. Conchyliol. 14, 162. Type-locality: near Bumbo River, Angola.

1873. Physa algoensis Sowerby. Reeve, L., Conchologia Iconica, or Illustrations of the shells of molluscous animals, London, 19, plate 7, fig. 53. (Err. typ.)

1887. Physa parietalis Mousson. J. Conchyliol. 35, 298, plate 12, fig. 8-8a. Typelocality: Ondangua, Ovamboland.

This subspecies is very closely related to the nominate race, from which it differs by the usually more cylindrical shell, shorter spire, and narrower reflexion of the columella; such characters, however, are not very inmportant within this group. Sufficient material for a decision of the validity of the subspecies has not been available, and it is listed here with reservation.

The mean measurements of seven shells from Lufinda, Angola, are as follows-H: $12.7 \mathrm{~mm}$; D: $8.2 \mathrm{~mm}$; and A: $8.9 \mathrm{~mm}$.

"Physa" welwitschi seems to be an unusually large specimen, measuring $20 \mathrm{~mm}$ in height and $13 \mathrm{~mm}$ in diameter.

"Physa" parietalis is apparently a smaller form of angolensis with a more strongly costate sculpture and usually, but not always, with a heavier callus. It is possible that this form should be referred rather to the nominate race, but as no specimens from Ovamboland have been available it is here put into the synonymy of angolensis because of the geographical distribution.

Material examined: Angola : Camana, Cafunda Cavilongo, Lufinda, Tchimpumpunhime River. Belgian Congo : Swakibula.

(10) B. (B.) tropicus zanzebaricus (Clessin)

(see Plate XII)

1886. Physa zanzebarica Clessin. Martini \& Chemnitz, Systematisches ConchylienCabinet, Berlin, 2. Aufl., vol. I: 17, 362, plate 51, fig. 5. Type-locality: Zanzibar.

Like all other subspecies of B. tropicus, this is very variable in shape of shell; it is hence extremely difficult to give a description that makes it possible always to distinguish it from the nominate race. The main difference is in the colour of the shell, which is much lighter than in B. t. tropicus. Further, the shell is often more cylindrical, with a more obtuse apex, and - as a rule-a somewhat twisted columella.

The mean measurements of eight shells from Lake Jipe are as follows$\mathrm{H}: 10.1 \mathrm{~mm}$; D: $7.5 \mathrm{~mm}$; and A: $7.6 \mathrm{~mm}$. The biggest specimen (from Singida, Tanganyika) has the following measurements-H: $17.6 \mathrm{~mm}$; D: $10.9 \mathrm{~mm}$; and A: $10.8 \mathrm{~mm}$.

Distribution: Tanganyika and the southern part of the Belgian Congo. 
When typically developed, this subspecies looks strikingly different from the nominate race, but in several localities shells more closely resembling the typical tropicus are found together with typical zanzebaricus and all intermediates, and as no differences in the internal organs could be discovered, it certainly represents a valid subspecies.

Material examined: Tanganyika Territory: Lake Jipe, Malya, Singida, Ngudu. Belgian Congo : Elisabethville, Kimpese.

\section{(11) B. (B.) tropicus mutandaensis (Preston)}

\section{(see Plate XIII)}

1913. Physa mutandaensis Preston. Rev. zool. afr. 3, 57, plate 5, fig. 8. Type-locality: Lake Mutanda, Kigezi, Uganda.

The common (but not the typical) form of this subspecies has a rather large inflated shell with a very low spire and a large aperture; the columella is usually straight and broadly reflexed. The typical form is smaller and has a more cylindrical shell and a twisted columella; it is endemic to Lake Mutanda and is certainly influenced by the particular conditions in that lake, since a similar form of $B$. (Ph.) ugandae has evolved there.

The mean measurements of 10 specimens of the common form from Kichwamba crater lake are as follows- $-\mathrm{H}: 14.0 \mathrm{~mm}$; D: $11.1 \mathrm{~mm}$; and A: $12.4 \mathrm{~mm}$. Those of 10 shells from Lake Mutanda are-H: $10.8 \mathrm{~mm}$; D: $7.8 \mathrm{~mm}$; and A: $8.4 \mathrm{~mm}$.

The radula teeth are slightly larger than those of the nominate race.

Distribution: lakes, mainly crater lakes in Kigezi and Ruanda.

Future studies must decide whether this form is a true subspecies or only an ecophenotypical form of $B$. t. zanzebaricus, from which it has certainly evolved.

Material examined: Belgian Congo: Lake Luhondo, Lake Mohasi, Lake Rugwero, Kibati, Mongbwalu, Bukama, Djungu. Uganda : Lake Mutanda, Lake Bunyoni, Kichwamba, Fort Portal, Isunga.

(12) B. (B.) tropicus alluaudi (Dautzenberg) (see Plate XIV)

1908. Physa alluaudi Dautzenberg. J. Conchyliol. 56, 17, plate 2, fig. 11-12. Typelocality: Nairobi River, Kenya.

1912. Physa permembranacea Preston. Rev. zool. afr. 1, 327, plate 17, fig. 8. Typelocality: Aberdare Range, Kenya.

1913. Physa exserta Preston. Rev. zool. afr. 3, 56, plate 5, fig. 9. Type-locality: Lake Baringo, Kenya.

1913. Physa syngenes Preston. Rev. zool. afr. 3, 56, plate 5, fig. 10. Type-locality: Lake Naivasha, Kenya.

1913. Physa laikipiaensis Preston. Rev. zool. afr. 3, 56, plate 5, fig. 14. Type-locality: Laikipia Plateau, Kenya.

1913. Physa rumrutiensis Preston. Rev. zool. afr. 3, 57. Type-locality: between Rumruti and Mount Kenya, Kenya. 
The typical form of this subspecies differs from the nominate subspecies by its (on average) larger size and more evenly rounded whorls, which give the shell a more regularly ovate appearance. It is, however, a very variable form, especially as regards relative length of spire and heaviness of shell.

The mean measurements of eight specimens from Nairobi River are as follows-H: $11.2 \mathrm{~mm}$; $\mathrm{D}: 8.3 \mathrm{~mm}$; and A: $8.1 \mathrm{~mm}$. The biggest shell (from Lake Naivasha) has the following dimensions-H: $17.1 \mathrm{~mm}$; D: $10.6 \mathrm{~mm}$; and $\mathrm{A}: 11.0 \mathrm{~mm}$.

The radula teeth are distinctly bigger than those of B. t. tropicus.

Distribution: the highlands of Kenya.

The five "species" described by Preston are all ecophenotypical forms of $B$. t. alluaudi.

Material examined: Kenya Colony : Lake Baringo, Marsabit, Mwea, Lake Naivasha, Sukari Dam, Ol Joro Orok, Eldama Ravine, Ruiru, Kabete, Nairobi, Limuru.

\section{(13) B. (B.) liratus (Tristram) (see Plate XV)}

1863. Physa lirata Tristram. Proc. zool. Soc. Lond. p. 60 (figure). Type-locality: west of Tananarive, Madagascar.

1877. Physa madagascariensis Angas. Proc. zool. Soc. Lond. p. 528, plate 54, fig. 2. Type-locality: Okongo, south-eastern Madagascar.

1882. Physa lamellata E. A. Smith. Proc. zool. Soc. Lond. p. 386, plate 22, fig. 14-15. Type-locality: 20 miles $(32 \mathrm{~km})$ from Tananarive.

1882. Physa obtusispirata E. A. Smith. Proc. zool. Soc. Lond. p. 386, plate 22, fig. 1617. Type-locality: about 20 miles $(32 \mathrm{~km})$ from Tananarive.

1886. Physa hildebrandti Clessin. Martini \& Chemnitz, Systematisches ConchylienCabinet, Berlin, 2. Aufl., vol. I: 17, 351, plate 47, fig. 12. Type-locality: Betsileo, Madagascar.

1936. Bulinus (Diastropha) contortus bullaceus Haas. Abh. senckenb. naturf. Ges. No. 431, p. 31, plate 1, fig. 17. Type-locality: Betsileo, Madagascar.

The shell is fragile, inflated, and ovate, and consists of four rounded whorls rapidly increasing in size and separated by a fairly deep suture. The spire is usually small and low. The aperture is very large and wide, with a sharp, fragile outer lip and a broadly reflexed columellar margin, which continues in a very broad callus. In most specimens the umbilicus is not completely closed. The sculpture of the shell consists of regular costulation, as a rule very distinct, but sometimes almost imperceptible. The colour is a dull yellowish-grey.

The mean measurements of 10 shells from Ambositra, Madagascar, are as follows- $\mathrm{H}: 14.6 \mathrm{~mm}$; $\mathrm{D}: 10.7 \mathrm{~mm}$; and $\mathrm{A}: 11.8 \mathrm{~mm}$.

In the internal organs $B$. liratus shows a great resemblance to $B$. tropicus, but the radula teeth are bigger.

Distribution: Madagascar. 
$B$. liratus is closely related to $B$. tropicus and is perhaps a subspecies; it seems, however, to be more distinguishable than the preceding forms, and is hence regarded as a separate species. Future breeding experiments must show whether this supposition is correct.

The forms listed above are placed in the synonymy of $B$. liratus because of the great similarity in the original descriptions. The main differences are in the relative length of spire and the size of shell. The supposed subspecies " $B$. contortus" described by Haas was established on shells with no costulation, but within the genus Bulinus this is a character of little systematic value.

Material examined: Madagascar: Ambositra, Marovoay.

(14) B. (B.) sericinus (Jickeli)

(see Plate XVI)

1874. Isidora sericina Jickeli. Jickeli, C. F., Nova Acta Leop. Carol. 37, 194, plate 7, fig. 11. Type-locality: Mekerka at Toquor River, Ethiopia.

1874. Isidora schackoi Jickeli. Jickeli, C. F., Nova Acta Leop. Carol. 37, 194, plate 7, fig. 12. Type-locality: Mekerka at Toquor River, Ethiopia.

1898. Isidora sericina mut. harpula Pollonera. Boll. Lab. Mus. Zool. Anat. Comp. Torino, 13, 11, plate, fig. 26-27. Type-locality: between Asmara and Debaroa, Eritrea.

1898. Isidora schackoi mut. minima Pollonera. Boll. Lab. Mus. Zool. Anat. Comp. Torino, 13, 12. Type-locality: Adi-Cani near Saganeiti, Eritrea.

The shell is rather small, usually regularly ovate, of a dark brownish colour, and consisting of four evenly rounded whorls rapidly increasing in size. The spire is of varying length, but typically rather short. The aperture is ovate with an evenly curved or somewhat flattened outer margin and a more or less broadly reflexed columellar margin, which is expanded over the narrow umbilicus. The sculpture consists of a distinct and regular fine costulation, but some shells are almost smooth.

The mean measurements of six shells from Lake Aramya, Ethiopia, are as follows-H: $8.9 \mathrm{~mm}$; D: $5.9 \mathrm{~mm}$; and A: $6.4 \mathrm{~mm}$. The biggest shell (from Asmara) has the following dimensions- $\mathrm{H}: 12.0 \mathrm{~mm}$; $: 7.6 \mathrm{~mm}$; and A: $8.3 \mathrm{~mm}$.

The typical form seems to be a fairly distinct species, characteristic for the north-eastern African highlands, but in the adjacent areas specimens have been found which appear to be intermediates between sericinus and other species. From Nubia and the Sudan intermediates between sericinus and truncatus are known, and from the north-eastern part of the Belgian Congo (Lake Gandu) I have seen a few specimens which are intermediary between sericinus and tropicus. Future studies of a far larger amount of material must decide whether sericinus should be regarded as a distinct species or not. 
It is with some reservation and mainly on account of the locality that "Isidora" schackoi is put into the synonymy of B. sericinus. According to Haas, ${ }^{6}$ it is a form of $B$. truncatus, to which it certainly shows a great resemblance. Jickeli gives the dimensions of the shell as follows- $\mathrm{H}: 17.5$ $\mathrm{mm}$; D: $10.0 \mathrm{~mm}$; and A: $10.9 \mathrm{~mm}$.

Material examined: Eritrea: Corbaria, Asmara, between Aduwa and Adigrat. Ethiopia: Lake Adeli, Lake Aramya, Bishoftu, Blue Nile. Belgian Congo: Lake Gandu. Egypt: El 'Alaqi, Abu Simbel, Ballana.

\section{(15) B. (B.) guernei (Dautzenberg)} (see Plate XVII, Fig. 14)

1890. Isidora guernei Dautzenberg. Mém. Soc. Zool. Fr. 3, 133, plate 1, fig. 11. Typelocality: near Tuabo, Senegal.

The shell is small, and consists of four rounded, somewhat shouldered whorls, separated by fairly deep sutures. The spire is rather prominent. The aperture has an evenly curved outer margin and a straight, narrowly reflexed columellar margin. The narrow umbilicus is, as a rule, not quite closed by the reflexion. The sculpture consists of faintly marked, widely separated ribs, but in some, chiefly not full-grown, shells the costulation is more pronounced, and is reminiscent of that of the preceding species. The colour is a dull brownish.

The mean measurements of eight specimens from Kumbidja, Gambia, are as follows $-\mathrm{H}: 8.1 \mathrm{~mm} ; \mathrm{D}: 6.3 \mathrm{~mm}$; and $\mathrm{A}: 5.5 \mathrm{~mm}$; but the dimensions of the type are bigger-H: $12 \mathrm{~mm}$; D: $9 \mathrm{~mm}$; and A: $8 \mathrm{~mm}$.

The internal organs are very similar to those of $B$. tropicus.

Distribution: West Africa from Senegal, Gambia, the Casamance River and eastward, at least as far as Firgoun on the Niger.

For the present it seems best to regard B. guernei as a distinct species, although it sometimes shows a great resemblance to $B$. sericinus. Future examination of the Bulinus forms in the intervening areas, for which no material has so far been available, must decide whether they are linked together by intermediary forms. It is also possible that Nigeria and French Equatorial Africa contain forms which connect this snail with the tropicus complex in Central Africa.

Material examined: French West Africa: Firgoun, Casamance River. Gambia: Kumbidje Bolon, Bora Kandakase.

The truncatus group

(16) B. (B.) transversalis (Martens)

(see Plate XVII, Fig. 15)

1897. Isidora transversalis Martens. Martens, Beschalte Weichtiere Deutsch Ost-Afrikas, Berlin, p. 139, plate 6, fig. 9. Type-locality: Bumbide Island, Lake Victoria. 
The shell is small, rather solid, and of a dark brownish colour. Normally the spire is quite low and rounded, but some shells have a higher and more pointed spire. The aperture is typically drawn out transversely and has a deeply curved outer margin; the lower part of the columellar margin is oblique. The sculpture consists of rather coarse growth lines.

The mean measurements of 10 specimens from Jinja Bay are as follows$\mathrm{H}: 7.2 \mathrm{~mm}$; D: $6.3 \mathrm{~mm}$; and A: $6.2 \mathrm{~mm}$. The biggest shell from the same population measures as follows-H: $7.6 \mathrm{~mm}$; $\mathrm{D}: 6.4 \mathrm{~mm}$; and $\mathrm{A}: 6.7 \mathrm{~mm}$. In well-developed shells in which the characteristic features are very pronounced, the diameter may be equal to the height or even greater.

The lateral teeth of the radula have arrowhead-shaped mesocones as in $B$. truncatus, but the teeth are considerably smaller. If the copulatory organ is present, it is of the same type as in B. truncatus trigonus.

Distribution: known only from Lake Victoria and the first part of the Victoria Nile.

The author ${ }^{10}$ regarded this form as a subspecies of $B$. trigonus, but since then a much larger amount of material has been examined, and there can hardly be any doubt about its specific distinctness. It lives usually in shallow water along the shore, very often in company with $B$. truncatus trigonus, and no intermediates have been found hitherto. Living specimens resemble to a very high degree young Physopsis on account of the dark shell.

$B$. transversalis connects the tropicus group with the truncatus group. The dark shell and animal refer to the first group, and the radula and the frequently lacking copulatory organ to the seond.

Material examined: Uganda: Jinja Bay, Buvuma Channel, Lake Nabugabo, Bukasse Island, Ramafuta Island, Victoria Nile at Owen Falls and Bujagali.

\section{B. (B.) truncatus truncatus (Audouin) ${ }^{a}$ (see Plates XVIII, XIX)}

1827. Physa truncata Audouin. Audouin, V., Explication sommaire des planches de mollusques de l'Egypte et de la Syrie, publiées par J.-C. Savigny, offrant un exposé des caractères naturels des genres avec la description des espèces, Paris, p. 166. Type-locality: Egypt.

1831. Isidora hemprichii Ehrenberg. Ehrenberg, C. G., Symbolae Physicae seu Icones et Descriptiones Animalium Evertebratorum, Berlin, vol. I, p. 19. Type-locality: Alexandria.

1831. Isidora brocchii Ehrenberg. Ehrenberg, C. G., Symbolae Physicae seu Icones et Descriptiones Animalium Evertebratorum, Berlin, vol. I, p. 20. Type-locality: Beirut, Lebanon.

1841. Physa guerini Mittre. Rev. Zool. Soc. Cuvier, p. 68. Type-locality: "Levant".

1856. Physa saulcyi Bourguignat. Rev. Mag. Zool. (2), 8, 230, plate 15, fig. 14-16. Type-locality: Alexandria.

$a$ Only the names of forms recorded from Africa are given here; a complete list of synonyms would include forms from northern and eastern Mediterranean countries. 
1856. Physa raymondiana Bourguignat. Rev. Mag. Zool. (2), 8, 233, plate 15, fig. 8-10. Type-locality originally given as Bône, Algeria, but in 1864 (Malacologie de l'Algérie, 5, 174 (footnote)) amended to Algiers.

1856. Physa brondelii Bourguignat. Rev. Mag. Zool. (2), 8, 234, plate 15, fig. 11-13. Type-locality originally given as Bône, Algeria, but in 1864 (see above) amended to Mostaghanem, Algeria.

1873. Physa mareotica Sowerby. Reeve, L., Conchologia Iconica, or Illustrations of the shells of molluscous animals, London, 19, plate 10, fig. 78. Type-locality: Lake Mareotis, Egypt.

1874. Physa contorta var. porrecta Martens. S. B. Ges. naturf. Fr. Berl. p. 65. Typelocality: Dakhl Oasis, Egypt.

1885. Physa aschersoni Clessin. Martini \& Chemnitz, Systematisches ConchylienCabinet, Berlin, 2. Aufl., vol. I: 17, 362, plate 51, fig. 2. Type-locality: Dakhl Oasis, Egypt.

1891. Physa dybowskii P. Fischer. In: Dybowski, J. (1892) L'extrême sud-algérien; contribution à l'histoire naturelle de cette région. Nouvelles Archives missions scientifiques et littéraires, 1, 365. Type-locality: southern Algeria.

1909. Bullinus innesi Pallary. Mém. Inst. égypt. 6, 53, plate 3, fig. 41-42. Type-locality: Cairo.

The shell is very variable in shape and size, but as a rule is of medium size, with a rather prominent spire, and consists of about four somewhat shouldered whorls. The aperture has an irregularly curved outer margin; the upper part of it is somewhat flattened, then follows a strong bend, and next to this a more flatly curved part again. The basal margin is usually more regularly curved. The columellar margin is straight and rather broadly reflexed. Generally the reflexion is not adnated to the surface of the shell but leaves the umbilicus open. The sculpture consists of somewhat irregular and rather coarse growth lines, but in some shells a more distinct costulation is present, especially on the whorls of the spire. In more rare cases the entire shell is costulate. The colour is usually a light yellowish-grey or brownish.

The mean measurements of 10 specimens from Gehabliya, Egypt, are as follows- $\mathrm{H}: 14.6 \mathrm{~mm}$; $\mathrm{D}: 10.0 \mathrm{~mm}$; and A: $9.4 \mathrm{~mm}$. The maximum size is almost $20 \mathrm{~mm}$ in height.

The body of the snail is usually of a light greyish colour with black spots on the mantle, but darker animals are not uncommon. The large radula teeth have arrowhead-shaped mesocones on the lateral teeth. The copulatory organ is not always developed.

Distribution (in Africa): North Africa and the Nile Valley. The southernmost record is Buyende in Uganda, but the specimens from this locality are not very typical.

"Isidora" hemprichii and brochii, both described by Ehrenberg, are based respectively upon the costulate and smooth forms of $B$. truncatus. The type of brochii is from Beirut, but Ehrenberg recorded it from Cairo also. "Physa" guerini is a doubtful form which has never been illustrated. "Physa" saulcyi is apparently nothing but a well-developed B. truncatus. 
"Physa" raymondiana, contortus var. porrecta, aschersoni, dybowskii, and innesi are all long-spired forms of B. truncatus. "Physa" mareotica is very poorly described and illustrated.

Unfortunately it is very doubtful that the name $B$. truncatus has any nomenclatorial validity (see Haas), ${ }^{6}$ but as it would certainly cause much confusion if this commonly accepted name for a most important species should be changed, it seems advisable to retain it. If it is rejected, the proper name for the Egyptian form would be $B$. contortus hemprichii (Ehrenberg). “Physa" contorta Michaud (1829, Bull. Soc. Linn. Bordeaux, 3, 268) represents another subspecies than the Egyptian, but they are undoubtedly conspecific.

Material examined: Egypt : Cairo, Maadi, Embaba, Beni Suef, Dessuq, Kafr Demera, Qaliub, Iskander Drain, Shalaqan, Matariya, Bilbeis Drain, Gehabliya Canal, Khadrawat Canal, Armenna. Sudan: Wad Medani, Gezira. Uganda: Buyende.

(18) B. (B.) truncatus trigonus (Martens)

(see Plate XX, Fig. 17)

1892. Physa trigona Martens. S. B. Ges. naturf. Fr. Berl. p. 17. Type-locality: Bukome, south-western part of Lake Victoria.

1897. Isidora strigosa Martens. Martens, Beschalte Weichtiere Deutsche Ost-Afrikas, Berlin, page 139, plate 6, fig. 11. Type-locality: Lake Victoria at Bukoba.

The shell is inversely coniform, with a very flat spire, and consists of about three whorls rapidly increasing in size. On account of the flat spire, the aperture becomes relatively higher than in other Bulinus. The upper part of the outer margin is flat, then follows an almost right-angled bend into the evenly, but rather flatly, curved greater part of the margin. The columellar margin is straight, and its reflexed portion does not completely close the narrow umbilicus. The sculpture on the first whorls is an obsolete costulation, while the last whorl is almost smooth. The colour is usually a pale yellowish-grey.

The mean measurements of 10 shells from Entebbe, Uganda, are as follows-H: $9.1 \mathrm{~mm}$; D: $8.2 \mathrm{~mm}$; and A: $8.6 \mathrm{~mm}$. The type-specimen is said to measure $11 \mathrm{~mm}$ in all three measurements, but the biggest seen (among several hundreds) does not exceed $10 \mathrm{~mm}$ in height.

The internal organs do not differ from those of the nominate subspecies, but aphallic specimens seem to be much more common. Of 100 specimens from Jinja Bay, only six had a developed copulatory organ.

Distribution: Lakes Edward and Victoria, the first part of the Victoria Nile, and a few dams and streams in Uganda.

"Isidora strigosa" does not differ from trigonus in any characters other than the spire, which is raised a little above the last whorl. This form is difficult to distinguish from $B$. coulboisi, but in case of doubt an examination of the radula will make it clear. 
Material examined: Uganda: Jinja, Napoleon Gulf, Buvuma Channel, Entebbe, Bukone, Bukakata, Dagusi Island, Victoria Nile at Ripon Falls, Bujagali, Forest Station, and Simba Falls, stream in Mabira Forest, Kazinga Channel, Serere, Mbarara, Lake Edward, Lake Bunyoni. Kenya Colony: Kavirondo Gulf. Tanganyika Territory: Mwanza, Ilemera, Bukoba, Kyaka.

\section{B. (B). truncatus rohlfsi (Clessin)} (see Plate XX, Fig. 18)

1886. Physa rohlfsi Clessin. Martini \& Chemnitz, Systematisches Conchylien-Cabinet, Berlin, 2. Aufl., vol. I: 17, 349, plate 49, fig. 7. Type-locality: Kuka (Koukia?) at Lake Chad.

1905. Physa (Isidora) tchadiensis Germain. Bull. Mus. Hist. nat., Paris, 11, 485. Typelocality: Lake Chad.

1907. Physa (Isidora) vaneyi Germain. Bull. Mus. Hist. nat., Paris, 13, 65. Typelocality: Kouri archipelago, Lake Chad.

1907. Physa (Isidora) ioubini Germain. Bull. Mus. Hist. nat., Paris, 13, 273, fig. 22. Type-locality: Lake Chad at Kouloua.

No specimens from Lake Chad have been available for this study. The forms listed above are classed together here because of the impossibility of distinguishing them from each other on the basis of the original descriptions. Also the other forms of Bulinus from Lake Chad (strigosus, trigonus and truncatus) recorded by Germain in various papers undoubtedly belong to rohlfsi. When rohlfsi is here regarded as a subspecies of $B$. truncatus, it is because the author has had the opportunity of examining some specimens probably belonging to one and the same species, but coming from areas as distant as Ghana, the British Cameroons, and Jebel Marra in Darfur. All of them are closely related to rohlfsi as regards the shell, and their anatomical features (radula, and presence or absence of copulatory organ) show a great similarity with those of $B$. truncatus. However, a final decision cannot be made until much more and better material has been examined.

Material examined: Sudan : Jebel Marra. British Cameroons : Lake Barombi Kotto. Ghana : Koluandor, Dawa, Wa reservoir.

(20) B. (B.) nyassanus (Smith)

(see Plate XXI, Fig. 19)

1877. Physa nyassana E. A. Smith. Proc. Zool. Soc. Lond. p. 717, plate 75, fig. 16-17. Type-locality: Lake Nyasa.

1877. Physa succinoides E. A. Smith. Proc. Zool. Soc. Lond. p. 718, plate 75, fig. 19-20. Type-locality: Lake Nyasa.

The shell is small, but more solid than in other Bulinus; it consists of four somewhat shouldered whorls separated by deep, groove-like sutures. The spire is very short, and either blunt or slightly pointed. The aperture 
is high and wide, with a broadly curved outer margin and a narrow and solid, but only slightly reflexed, columellar margin. The sculpture consists of delicate but distinct transverse lines.

The measurements of the type-specimen are as follows $-\mathrm{H}: 10.0 \mathrm{~mm}$; D: $8.5 \mathrm{~mm}$; and A: $9.0 \mathrm{~mm}$.

The only specimen dissected was aphallic. Its radula teeth are relatively very large, and already the first lateral tooth has a bifid mesocone and ectocone.

Distribution: Lake Nyasa.

Only a small fresh specimen and a bigger "dead" shell have been available for examination. The smaller shows some resemblance with Smith's succinoides, while the bigger is undoubtedly identical with his nyassanus, but, since they definitely belong to the same species, "Physa" succinoides is here regarded as synonymous with $B$. nyassanus. Without doubt it represents the immature nyassanus, but more material is desirable.

Material examined: Nyasaland: Nkata Bay.

\section{(21) B. (B.) coulboisi (Bourguignat)}

(see Plate XXI, Fig. 20)

1888. Physa coulboisi Bourguignat. Bourguignat, J. R., Iconographie malacologique des animaux mollusques fluviatiles du lac Tanganika, Corbeil, plate 1, fig. 24-25. Type-locality: western shore of Lake Tanganyika.

1888. Physa randabeli Bourguignat. Bourguignat, J. R., Iconographie malacologique des animaux mollusques fluviatiles du lac Tanganika, Corbeil, plate 1, fig. 26-27. Type-locality: Ubuari Peninsula, Lake Tanganyika.

The shell is usually rather small and fragile and consists of four rounded whorls. The typical form has a short, pointed spire, which in some shells, however, does not rise above the last whorl. The aperture has an evenly curved outer margin and a normally straight, but sometimes slightly twisted, columellar margin. No particular sculpture is present. The colour is a lighter or darker brownish-horn.

The mean measurements of 10 specimens from Lake Tanganyika at Albertville are as follows- $-\mathrm{H}: 9.3 \mathrm{~mm}, \mathrm{D}: 7.3 \mathrm{~mm}$; and A: $7.1 \mathrm{~mm}$. The biggest shell (from Lake Kivu) has the following dimensions- $-\mathrm{H}: 11.4 \mathrm{~mm}$; D: $8.0 \mathrm{~mm}$; and A: $7.3 \mathrm{~mm}$.

The lateral teeth of the radula have simple triangular cusps as in the tropicus group, but the general appearance of the snail and the frequent absence of the copulatory organ agree better with the truncatus group.

Distribution: Lakes Tanganyika, Kivu, Edward, Albert, Kyoga, and most likely also Nyasa; in addition, some of the smaller lakes in RuandaUrundi and Rutshuru.

It is not possible to distinguish with certainty between this species and 
B. $t$ trigonus on shell characters alone, but an examination of the radula makes classification easy.

"Physa" randabeli seems to be an unusually big B. coulboisi with a height of $12 \mathrm{~mm}$.

Material examined: Sudan: Nimule. Uganda: Packwach, Panyimur, Butiaba, Kibiro, Masindi Port, Bugondo. Belgian Congo: Kaseke, Bukavu, Albertville, Lake Mohasi, Lake Kirwa.

The forskalii group

(22) B. (B.) camerunensis n. sp.

(see Plate XXII, Fig. 21 (a))

The shell consists of from four to four-and-a-half rounded or slightly shouldered whorls separated by deep sutures. The spire is prominent, varying in height from a little more than half to four-fifths of the length of the aperture. This is rather narrow and has a slightly curved outer margin, a strongly curved basal margin, and a usually straight and somewhat reflexed columellar margin. In most specimens the umbilicus is not completely closed by the reflexion. The sculpture consists of delicate transverse striae. The colour is a very pale yellowish or almost white.

The mean measurements of 10 specimens are as follows $-\mathrm{H}: 6.1 \mathrm{~mm}$; D: $3.7 \mathrm{~mm}$; and A: $3.5 \mathrm{~mm}$.

The radula teeth are very small, distinctly smaller than those of forskalii, but of the same shape. The genital organs do not differ from those of forskalii.

Distribution: known only from Lake Barombi Kotto, south-west of Kumba, British Cameroons.

It is not impossible that this form is in reality a strongly modified form of $B$. forskalii, but the peculiar shell and the much smaller radula teeth seem to justify its creation as a new species. Judging from the shell alone, it would be reasonable to regard it as a dwarf form of $B$. t. rohlssi, but the structure of the radula contradicts such a supposition, and similarly makes it unlikely that it derives from $B$. senegalensis. It would be of interest to know whether $B$. (B.) camerunensis also occurs in other lakes in that part of Africa.

Material examined: British Cameroons : Lake Barombi Kotto.

(23) B. (B.) reticulatus Mandahl-Barth (see Plate XXII, Fig. 21 (b, c))

1954. Bulinus reticulatus Mandahl-Barth. Ann. mus. Congo Belge, 8vo., 32, 109, fig. 51. Type-locality: Kanyakwar Wells, Kisumu, Kenya.

The shell is very small, consisting of four-and-a-half rounded whorls of which the first is smooth and the following are provided with regular, 
fine, close-set ribs, sometimes, but not always, crossed by delicate spiral lines. The spire is rather prominent, almost equal in length to the aperture, which is rather small. The outer margin is evenly curved and the columellar margin is straight and broadly reflexed. The reflexion does not close the open umbilicus. The colour is greyish or brownish.

The dimensions of the shell are as follows-H: $4.5 \mathrm{~mm}$; D: $3.4 \mathrm{~mm}$; and A: $2.5 \mathrm{~mm}$.

The radula teeth are very small. The endocone and the mesocone on the lateral teeth are not completely separated. The copulatory organ usually has a preputium which is distinctly longer and wider than the vergic sheath.

Distribution: eastern Africa from Kenya to Southern Rhodesia, but nowhere very common.

B. reticulatus has been found hitherto only in pools or ditches that are completely dried up during the greater part of the year. It cannot therefore be excluded that in reality it is an ecophenotypical form evolved under particularly unfavourable conditions, but it has been impossible to find any closer relation to another species; it thus seems better to regard it as a distinct species until laboratory experiments possibly have proved the contrary to be the case. In some localities it has been found together with B. forskalii and B. scalaris.

Both this and the foregoing species could just as well be referred to the truncatus group.

Material examined: Kenya Colony: Kongoni Pool, Kanyakwar Wells, Kisumu. Tanganyika Territory: Moshi. Northern Rhodesia: Mazabuka. Southern Rhodesia : Salisbury.

$$
\begin{aligned}
& \text { (24) B. (B.) cernicus (Morelet) } \\
& \text { (see Plate XXII, Fig. } 21 \text { (d)) }
\end{aligned}
$$

1867. Physa cernica Morelet. J. Conchyliol. 15, 440. Type-locality: Mauritius.

?1856. Physa fischeriana Bourguignat. Rev. Mag. Zool. (2), 8, 18, plate 2, fig. 1-3. Typelocality: Ethiopia.

?1872. Physa beccarii Paladilhe. Ann. Mus. stor. nat. Genova, 3, 23, plate 1, fig. 7-8. Type-locality: Aden.

The shell consists of five only slightly rounded whorls of which the first is frequently lacking. The sutures are very shallow. The spire is equal in length to the aperture, which has an evenly, but not strongly, curved outer margin and a straight, somewhat reflexed columellar margin. The lower part of the reflexion is not adnated. The colour is a shiny brown, and the sculpture consists of very fine transverse lines crossed by delicate spiral lines at irregular intervals.

Germain ${ }^{5}$ states the maximum size to be $-\mathrm{H}: 9.5 \mathrm{~mm}$; D: $4.0 \mathrm{~mm}$; and $A: 4.5 \mathrm{~mm}$. All the specimens examined had only four whorls and a height of about $5 \mathrm{~mm}$. 
The only difference in the soft anatomy from that of $B$. forskalii is in the radula; B. cernicus has much narrower central and lateral teeth than forskalii, and the cusps are much longer. The endocone and the mesocone on the lateral teeth are coalescent for more than half their length, while in forskalii they are completely separated.

Distribution: known with certainty only from Mauritius.

The two species listed above as synonyms are very doubtful; Germain ${ }^{5}$ and Haas ${ }^{7}$ regard them as synonyms.

Sometimes another Bulinus ("B." borbonicus) is recorded from Mauritius, but this is a mis-identification; borbonicus is not a Bulinus, but a true Physa.

Material examined: Mauritius: Union Vale.

\section{(25) B. (B.) forskalii (Ehrenberg) \\ (see Plates XXIII, XXIV)}

1831. Isidora forskalii Ehrenberg. Ehrenberg, C. G., Symbolae Physicae seu Icones et Descriptiones Animalium Evertebratorum, Berlin, vol. I, p. 20. Type-locality: Damietta, Egypt.

1848. Physa wahlbergi Krauss. Krauss, Die südafrikanischen Mollusken, Stuttgart, p. 84, plate 5, fig. 13. Type-locality: Limpopo River, Transvaal.

1853. Bulinus schmidtii Dunker, Dunker, G., Index Molluscorum, quae in itinere ad Guineam inferiorem collegit Georgius Tams. Cassel, p. 9, plate 2, fig. 7-8. Typelocality: Benguela, Angola.

1855. Isidora lamellosa Roth. Malak. Bl. 2, 49, plate 2, fig. 14-15. Type-locality: River Nile, Egypt.

1868. Physa capillacea Morelet. Morelet, Voyage du $D^{r}$ Fr. Welwitsch dans les Royaumes d'Angola et de Bengueıa, Paris, p. 89, plate 8, fig. 1. Type-locality: Libongo district, Angola.

1868. Physa crystallina Morelet. Morelet, Voyage du $D^{r}$ Fr. Welwitsch dans les Royaumes d'Angola et de Benguela, Paris, p. 89, plate 9, fig. 1. Type-locality: Quiapose River near Sange, Angola.

1868. Physa apiculata Morelet. Morelet, Voyage du $D^{r}$ Fr. Welwitsch dans les Royaumes d'Angola et de Benguela, Paris, p. 90, plate 8, fig. 3. Type-locality: Loanda district, Angola.

1868. Physa canescens Morelet. Morelet, Voyage du $D^{r}$ Fr. Welwitsch dans les Royaumes d'Angola et de Benguela, Paris, p. 90, plate 9, fig. 3. Type-locality: Bengo River, Angola.

1868. Physa semiplicata Morelet. Morelet, Voyage du $D^{r}$ Fr. Welwitsch dans les Royaumes d'Angola et de Benguela, Paris, p. 91. Type-locality: Pungo Adongo district, Angola.

1868. Physa turriculata Morelet. Morelet, Voyage du $D^{r}$ Fr. Welwitsch dans les Royaumes d'Angola et de Benguela, Paris, p. 92, plate 9, fig. 7. Type-locality: Lucala River, Angola.

1868. Physa clavulata Morelet. Morelet, Voyage du $D^{r}$ Fr. Welwitsch dans les Royaumes d'Angola et de Benguela, Paris, p. 93, plate 9, fig. 6. Type-locality: Dande River, Angola.

1873. Physa vitraea " Parreyss" Sowerby. Reeve, L., Conchologia Iconica, or Illustrations of the shells of molluscous animals, London, 19, Physa, plate 8, fig. 65. Typelocality: Lake Mareotis, Egypt. 
1873. Physa benguelensis Sowerby. Reeve, L., Conchologia Iconica, or Illustrations of the shells of molluscous animals, London, 19, Physa, plate 9, fig. 77. Typelocality: Benguela, Angola.

1879. Pyrgophysa mariei Crosse. J. Conchyliol. 27, 208. Type-locality: Nosi Bé, northwest of Madagascar.

1894. Pyrgophysa bavayi Dautzenberg. J. Conchyliol. 42, 103, plate 3, fig. 7. Typelocality: near Diego Suarez, Madagascar.

1898. Physa gradata Melvill and Ponsonby. Ann. Mag. nat. Hist. (7), 2, 129, plate 7, fig. 8. Type-locality: Brickfields, Grahamstown, Cape Province.

1905. Physa moreleti Nobre. Ann. Sci. nat. Porto, p. 117, plate 1, fig. 29-30. Typelocality: Luinha, Angola.

1905. Physa osorioi Nobre. Ann. Sci. nat. Porto, p. 117, plate 1, fig. 31-32. Typelocality: Gumba, Angola.

1905. Physa (Pyrgophysa) dautzenbergi Germain. Bull. Mus. Hist. nat., Paris, 11, 486. Type-locality: Lake Chad.

The full-grown shell is long and-as a rule-slender, with a spire which is distinctly longer than the aperture. There are about six more or less shouldered whorls separated by fairly deep sutures. The relatively small aperture has a curved outer margin and a usually twisted, but sometimes straight columellar margin, which in some specimens is thickened and not reflexed, while in others it may be more or less broadly reflexed and either adnated or free. The sculpture consists of a more or less pronounced costulation, at least on the second and third whorls; the first one is normally smooth. A spiral sculpture of delicate lines may be present. The colour is usually light, often almost white or hyaline, more rarely darker and brownish.

The dimensions of the shell also vary considerably. The height of apparently full-grown shells may be as little as $8 \mathrm{~mm}$ or as much as $17 \mathrm{~mm}$. Some shells are almost cylindrical, while others are ovate or conical. The mean measurements of some lots of different size and shape are as follows:

Liberia-H: $8.4 \mathrm{~mm}$; D: $3.2 \mathrm{~mm}$; and A: $4.2 \mathrm{~mm}$

Lake Tanganyika- $\mathrm{H}: 8.6 \mathrm{~mm}$; D: $3.2 \mathrm{~mm}$; and A: $3.5 \mathrm{~mm}$

Uganda-H: $10.2 \mathrm{~mm}$; D: $3.8 \mathrm{~mm}$; and A: $3.9 \mathrm{~mm}$

Dahomey-H: $12.7 \mathrm{~mm}$; D: $4.1 \mathrm{~mm}$; and A: $4.7 \mathrm{~mm}$

Transvaal-H: $13.6 \mathrm{~mm}$; D: $4.8 \mathrm{~mm}$; and A: $4.5 \mathrm{~mm}$

Kenya-H: $14.4 \mathrm{~mm}$; D: $4.2 \mathrm{~mm}$; and A: $5.3 \mathrm{~mm}$

Lower Congo- $-\mathrm{H}: 17.0 \mathrm{~mm}$; D: $5.4 \mathrm{~mm}$; and A: $6.8 \mathrm{~mm}$.

The radula teeth are small, and characterized by the completely separated cusps on the lateral teeth. The copulatory organ is relatively small and slender, but rather variable in proportions.

Distribution: Egypt, Africa south of the Sahara, and Madagascar.

As indicated by the long list of synonyms, B. forskalii is an extremely variable species. Although some quite distinct forms seem to be restricted to certain areas, it is not possible to regard them as true subspecies because typical forms occur in the same areas. Among the most characteristic of 
these aberrant forms may be mentioned "Bulinus schmidtii" and "Physa dautzenbergi ".

"Bulinus schmidtii" Dunker (with most of Morelet's Angolese "species" as synonyms) differs from the typical forskalii by the usually shorter spire and more pronounced shoulder angle (see Plate XXIV, Fig. 22 (g)). "Physa crystallina" has the shortest spire of them all and is generally regarded as belonging to the truncatus group. Schmidtii seems to be restricted to Angola, Lower Congo, and probably also French Congo, but both in Angola and in Lower Congo the typical form of forskalii is common.

"Physa dautzenbergi" Germain has an almost cylindrical, often brownish, shell with an obtuse apex (see Plate XXIV, Fig. 22 (h)), and thus differs somewhat from the typical forskalii with which it agrees in all anatomical details. It is found only in tropical West Africa, where typical forskalii are also to be found. Neither schmidtii nor dautzenbergi can be regarded as valid species, because all intermediate stages between these forms and the typical forskalii are known.

"Physa canescens" is perhaps the strangest of the forskalii forms (see Plate XXIV, Fig. 22 (k, 1)): Anatomically it does not differ from the typical form, but the shell is strikingly different, looking more like a land shell of the family Enidae. The only lot of canescens seen by the author was collected by Dr le Roux in a drinking trough for cattle in Northern Rhodesia-not a very natural habitat!

Material examined: Egypt: Kafr Haris, Qalama. Sudan: Kosti, Juba, Nimule. Uganda : Rhino Camp, Packwach, Butiaba, Lira, Iganga, Bugungu, Jarvis Dam, Malawa River, Nawanga River, Akoli Swamp. Kenya Colony: Kakamega, Kisumu, Nyando River, Kisal River, Lake Baringo, Mwea. Tanganyika Territory: Simiyu River, Mabuki, Mkorani River, Magu, Ngudu, Mwanza. Belgian Congo: Kongolo, Kindu, Bukavu, Albertville, Usumbura, Stanley Pool, Boma, Kudiboma, Kimpese, Matadi, Mateba Island. Angola: Camana, Tchimpumpunhine River. Northern Rhodesia: Lochinvar Farm. Southern Rhodesia: Salisbury. Transvaal : Nelspruit, Kaapmuiden. Natal : Umhlanga River. Madagascar: Ankara. Nigeria: Ibadan. Dahomey: Porto Novo. Ghana: Abladije, Tonsaing, Agona-Apowa Road. Liberia: Tappita. Gambia : Kartung, Keneba, Kiti, Bansang, Saja Kunda.

\section{(26) B. (B.) scalaris (Dunker)}

(see Plate XXV, Fig. 23 (a, b))

1845. Physa scalaris Dunker. Z. Malakozool. 2, 164. Type-locality: Benguela, Angola. 1898. Pyrgophysa nyangweensis Putzeys. Ann. Soc. malak. Belg. 33, 6, fig. 6. Typelocality: Nyangwe, Belgian Congo.

1905. Physa (Pyrgophysa) dunkeri Germain. Bull. Mus. Hist. nat., Paris, 11, 486 (new name for Physa scalaris Dunker)

The shell consists of about six evenly and not markedly rounded whorls, which have not the faintest trace of a shoulder angle. The outline of the 
shell is more evenly curved than in forskalii, with which it shows great resemblance. The costate sculpture is restricted to the first whorls, and is not as regular and pronounced as is usual in forskalii. On the second and third whorl very delicate spiral lines may be present. The colour of the shell is generally a pale yellowish brown.

The mean measurements of 10 specimens from Kisumu are as follows$\mathrm{H}: 11.5 \mathrm{~mm}$; $\mathrm{D}: 4.4 \mathrm{~mm}$; and A: $5.4 \mathrm{~mm}$. The biggest specimen is $12 \mathrm{~mm}$ in height.

FIG. 8. COPULATORY ORGAN OF FORSKALII GROUP
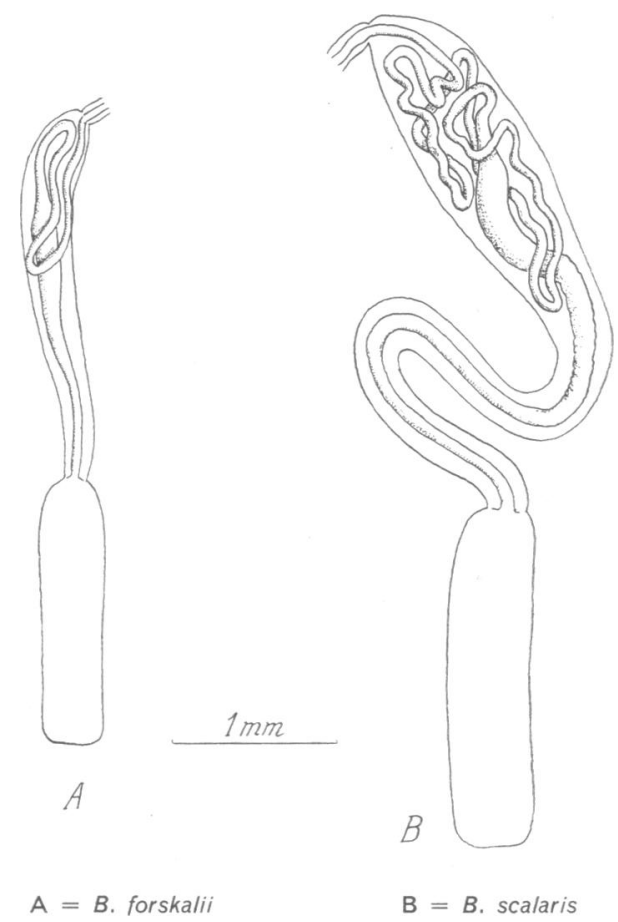

$\mathbf{B}=$ B. scalaris

The radula has exactly the same structure as in forskalii, but there is a very remarkable difference in the copulatory organ (see Fig. 8). It is much bigger than in forskalii, and the epiphallus (the part of the vas deferens running inside the vergic sheath) is very much longer. In forskalii the epiphallus is shorter than, or at most as long as, the vergic sheath, but in scalaris it is about twice as long.

Distribution: hitherto found in Angola, Belgian Congo and Uganda.

B. scalaris is undoubtedly a near relative of forskalii, but as they have been found together with no sign of interbreeding it is most reasonable to 
regard them as different species. Interbreeding is probably prevented by the size of the copulatory organ of scalaris.

Material examined: Kenya Colony: Kisumu, Kanyakwar Wells, Asembo. Uganda : Lira, Mbarara.

(27) B. (B.) senegalensis Müller

(see Plate XXV, Fig. 23 (c-f))

1781. Bulinus senegalensis O. F. Müller. Der Naturforscher, Halle, 15, 6 (new name for "Le Bulin" Adanson, 1857, Histoire naturelle de Sénégal; Histoire des coquilles, Paris, p. 5, plate 1). Type-locality: Podor, Senegal.

1850. Bulinus adansonii J. E. Gray. In: Gray, M. E., Figures of molluscan animals, London, vol. IV, p. 119 (new name for "Le Bulin" Adanson, 1857 (see above)).

1909. Bullinus bullin Pallary. Mém. Inst. égypt., 6, 51 (new name for "Le Bulin" Adanson, 1857 (see above)).

The shell consists of from five to five-and-a-half whorls and is relatively broader than in the two preceding species, being more ovate and less turreted. The whorls are more rounded than in scalaris and, like this, it shows no shoulder angle. The aperture is relatively higher, and the sculpture is much finer. It consists of fine transverse lines crossed by delicate spiral lines. The first two whorls show a more pronounced transverse sculpture.

The mean measurements of 10 specimens from Sanchabari Pool, Gambia, are as follows-H: $9.5 \mathrm{~mm}$; D: $4.4 \mathrm{~mm}$; and A: $5.2 \mathrm{~mm}$. The biggest specimen has a height of $11.1 \mathrm{~mm}$.

The body and the general anatomy show a great resemblance to forskalii, but the structure of the radula is quite different. The teeth are twice as big as those of forskalii and are rather of the truncatus type.

Distribution: known only from Senegal and Gambia, where it is found in pools and marshes.

$B$. senegalensis is the type of the genus Bulinus. Unfortunately, it has not been correctly classified hitherto, because the type-specimens are immature shells measuring only between $2 \mathrm{~mm}$ and $3.4 \mathrm{~mm}$ in height (Fischer-Piette). ${ }^{3}$ The immature shells have a dark peristome and look like adult shells. This dark peristome is often visible on the full-grown shell as a single or double dark transverse line on the third whorl from above.

Physa ludoviciana Mittre, 1841 (Rev. Zool. Soc. Cuvier, p. 68) described on the basis of an 18-mm high shell from Saint-Louis, Senegal, has never been illustrated nor rediscovered. It is possible that it represents the highest development of $B$. senegalensis, but on the other hand the possibility cannot be excluded that it is another species. Unfortunately, the description is very brief.

Material examined : Gambia : Daru Pool, Sara Njobo Pool, Cha Kunda, Sanchabari Pool, Belal Pool. 


\section{RÉSUMÉ}

L'auteur cherche à établir une classification de toutes les espèces de Bulinus africains qui ont été décrites. Il a examiné à cette fin un grand nombre de spécimens recueillis dans de nombreuses régions de l'Afrique. Il analyse les variations imputables à l'âge, au milieu et aux facteurs génétiques qui peuvent être observées dans les caractères taxinomiques et il établit un certain nombre d'espèces et sous-espèces nouvelles. Pour chaque espèce et sous-espèce reconnue, l'auteur précise les caractères distinctifs, indique la distribution géographique et donne une liste de synonymes.

\section{REFERENCES}

1. Connolly, M. (1925) Trans. roy. Soc. S. Afr. 12, 191

2. Cridland, C. C. (1955) J. trop. Med. Hyg. 58, 1

3. Fischer-Piette, E. (1942) Les mollusques d'Adanson, Rennes, p. 130

4. Germain, L. (1907) In: Chevalier, A. L'Afrique centrale française, Paris, p. 503

5. Germain, L. (1921) Faune malacologique terrestre et fluviatile des Iles Mascareignes, Angers, p. 237

6. Haas, F. (1935) Arch. Naturgesch. N.F. 4, 230

7. Haas, F. (1936) Abh. senckenb. naturf. Ges. No. 431.

8. Hubendick, B. (1948) Ark. Zool. Stockh. 40A, 1

9. Larambergue, M. de (1939) Bull. Biol. 73, 19

10. Mandahl-Barth, G. (1954) Ann. mus. Congo Belge, 8vo., 32, 105 


\section{ILLUSTRATIONS *}

* The measurement given for each figured specimen is the height of the shell. 
PLATE I
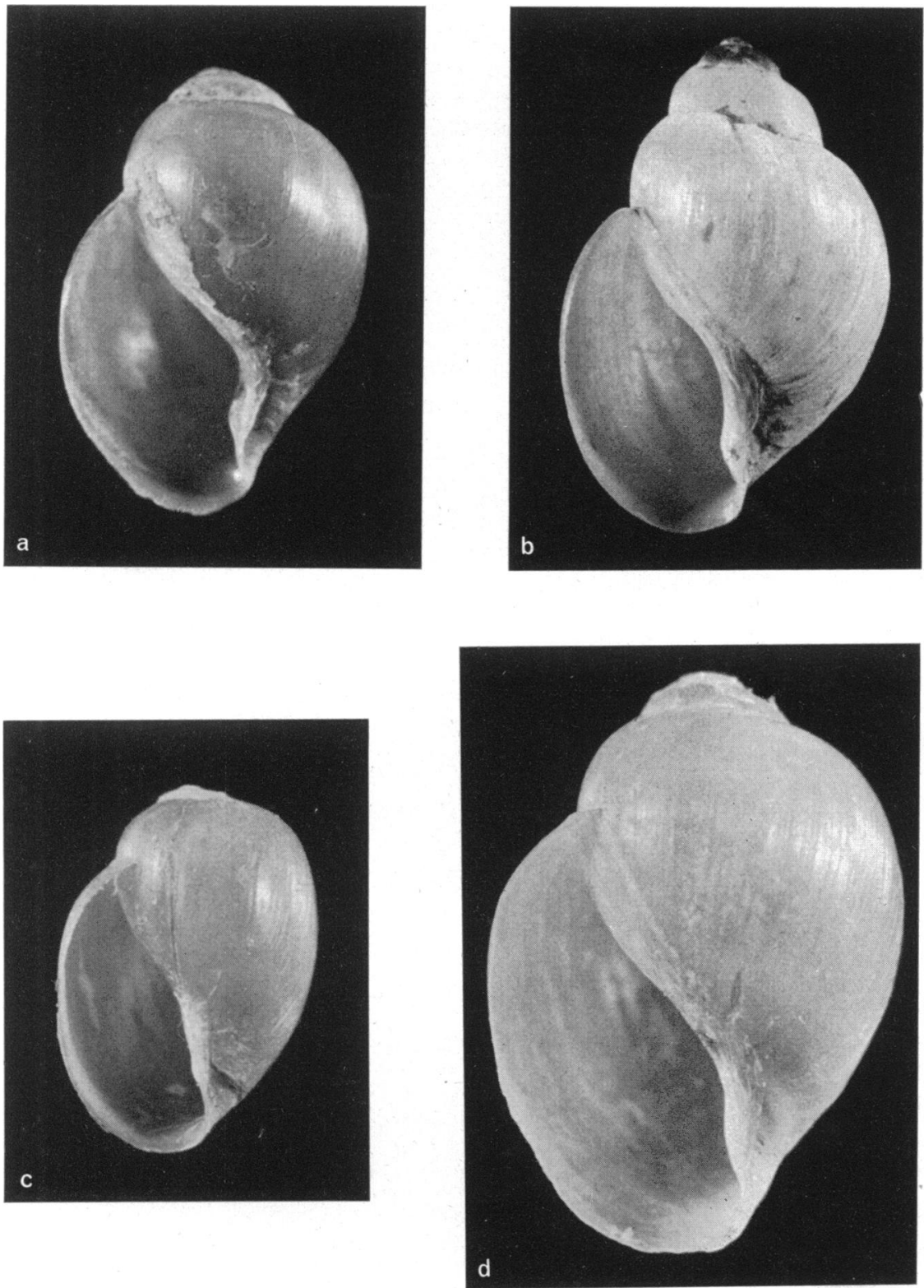

Fig. 1. B. africanus africanus. $a=$ Durban, $15.0 \mathrm{~mm} ; \mathrm{b}=$ Salisbury, Southern Rhodesia, $16.8 \mathrm{~mm} ; \mathrm{c}=$ Kafue Flats, Northern Rhodesia, $12.0 \mathrm{~mm}$; $\mathrm{d}=$ near Namwala, Northern Rhodesia, $19.1 \mathrm{~mm}$ 


\section{PLATE II}
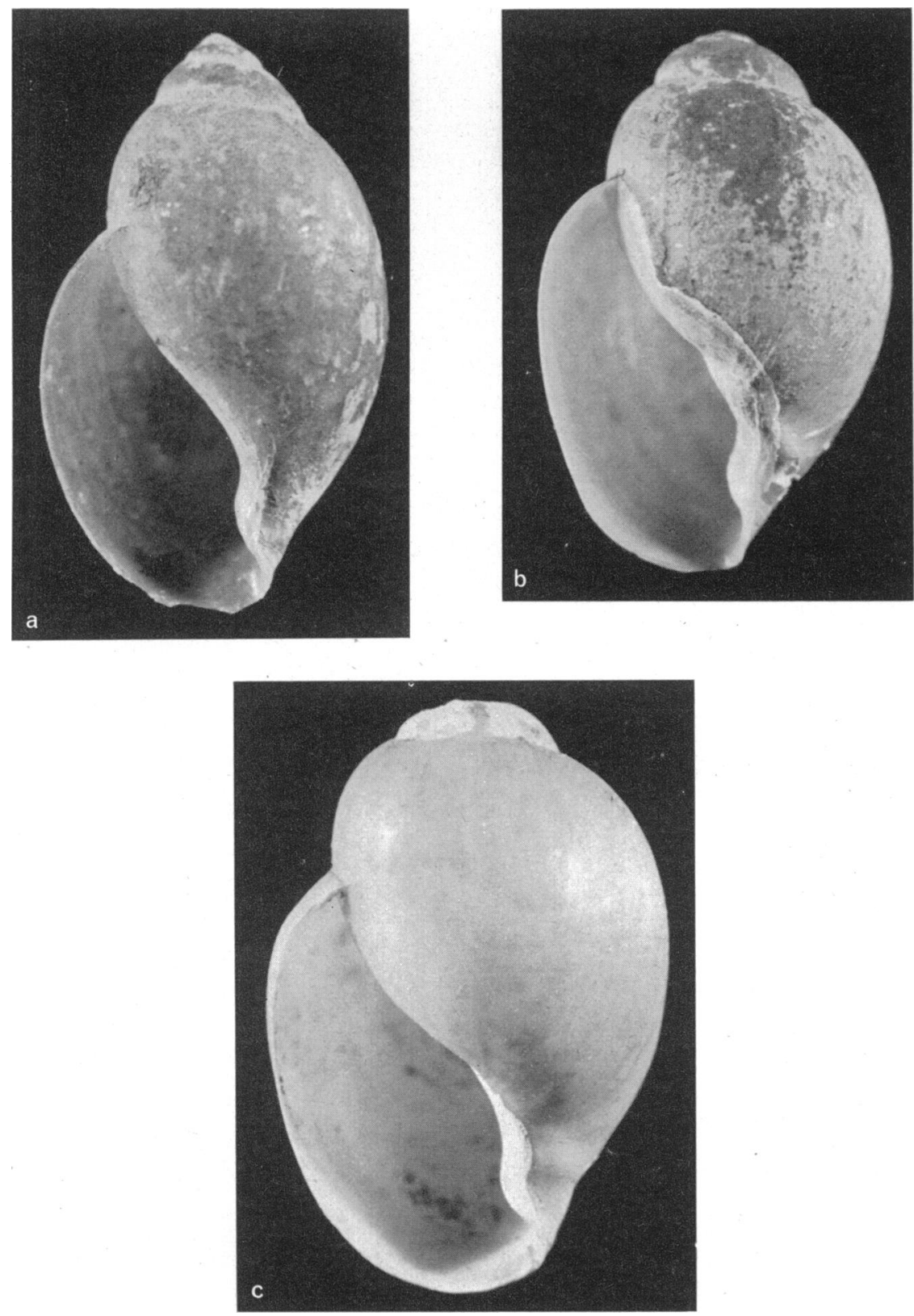

Fig. 2. B. africanus ovoideus. $a=$ Kasat River, Kenya, $16.8 \mathrm{~mm} ; b=$ Arua, West Nile, $17.2 \mathrm{~mm} ; \mathrm{c}=$ Laufori, Uganda, $18.0 \mathrm{~mm}$ 
PLATE III
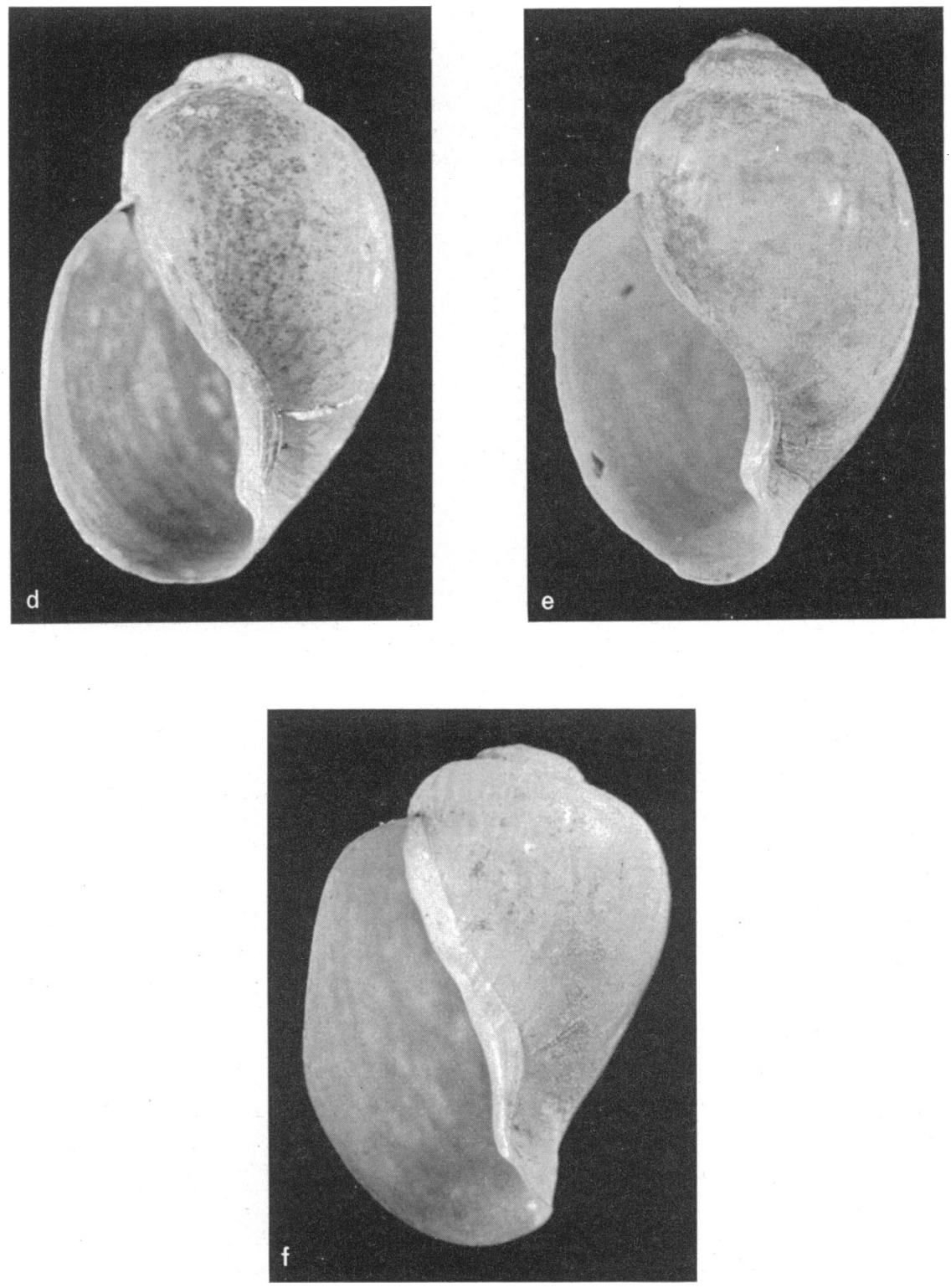

Fig. 2 (concluded). B. africanus ovoideus. $d=$ fish-pond at Nyakabera, Lake Kivu area, $17.5 \mathrm{~mm} ; \mathrm{e}=$ Great Kalemie River, Albertville, $17.5 \mathrm{~mm} ; f=$ Lake Tanganyika at Albertville, $16.8 \mathrm{~mm}$ 
PLATE IV
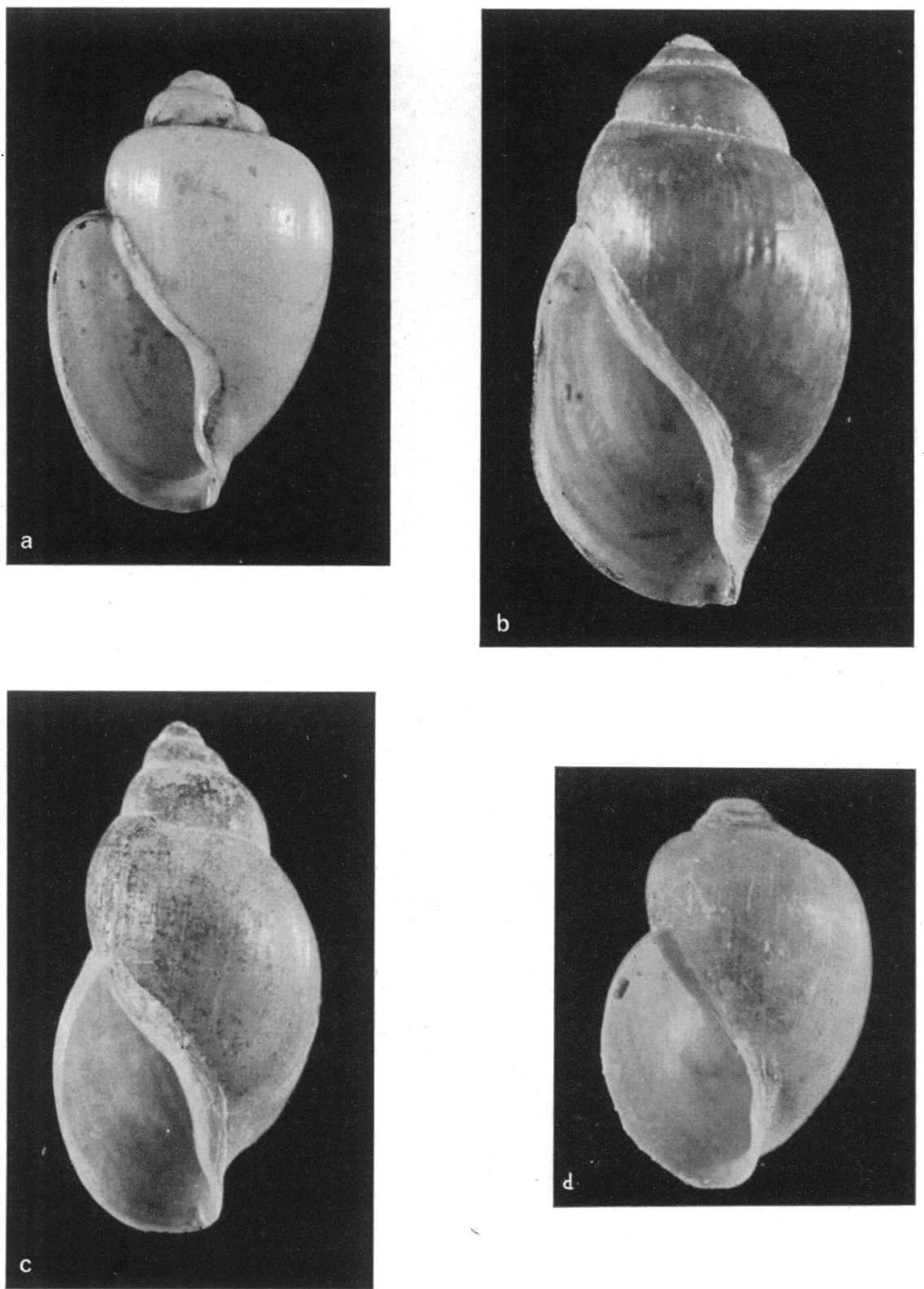

Fig. 3. $\mathrm{a}=$ B. abyssinicus, Moico, Somalia, $15.0 \mathrm{~mm} ; \mathrm{b}=$ B. nasutus, Zanzibar, $19.6 \mathrm{~mm} ; \mathrm{c}=B$. nasutus, Bugondo, Uganda, $17.5 \mathrm{~mm} ; \mathrm{d}=B$. ugandae, Kosti, Sudan, $12.2 \mathrm{~mm}$ 


\section{PLATE V}
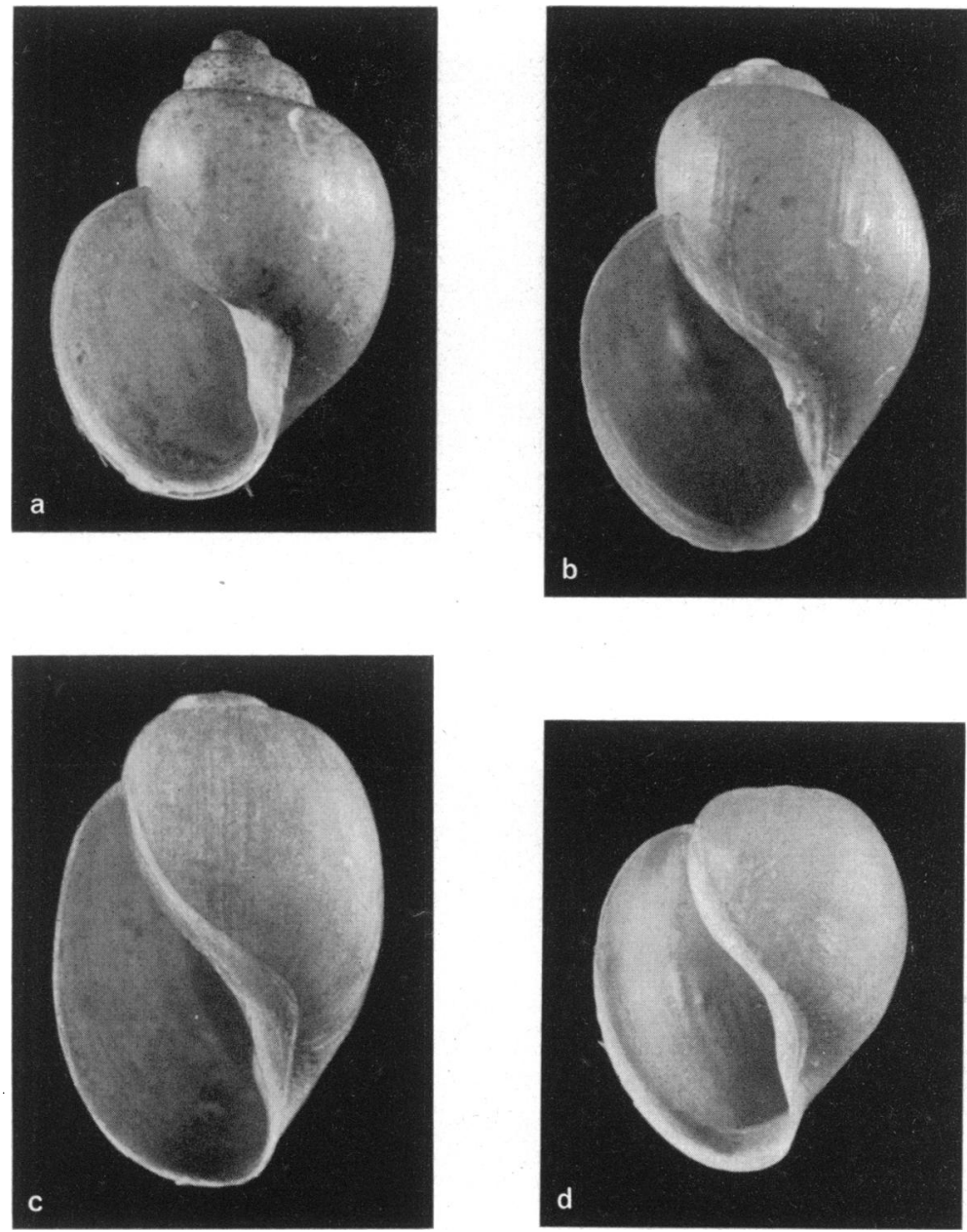

Fig. 4. B. ugandae. $a=$ Jinja Bay, Uganda, $12.7 \mathrm{~mm} ; b=$ Ussoma, near Kisumu, Kenya, $13.2 \mathrm{~mm} ; \mathrm{c}=$ Lake Mutanda, Uganda, $13.0 \mathrm{~mm}$; $\mathrm{d}=$ Victoria Nile, Uganda, $11.1 \mathrm{~mm}$ 
PLATE VI
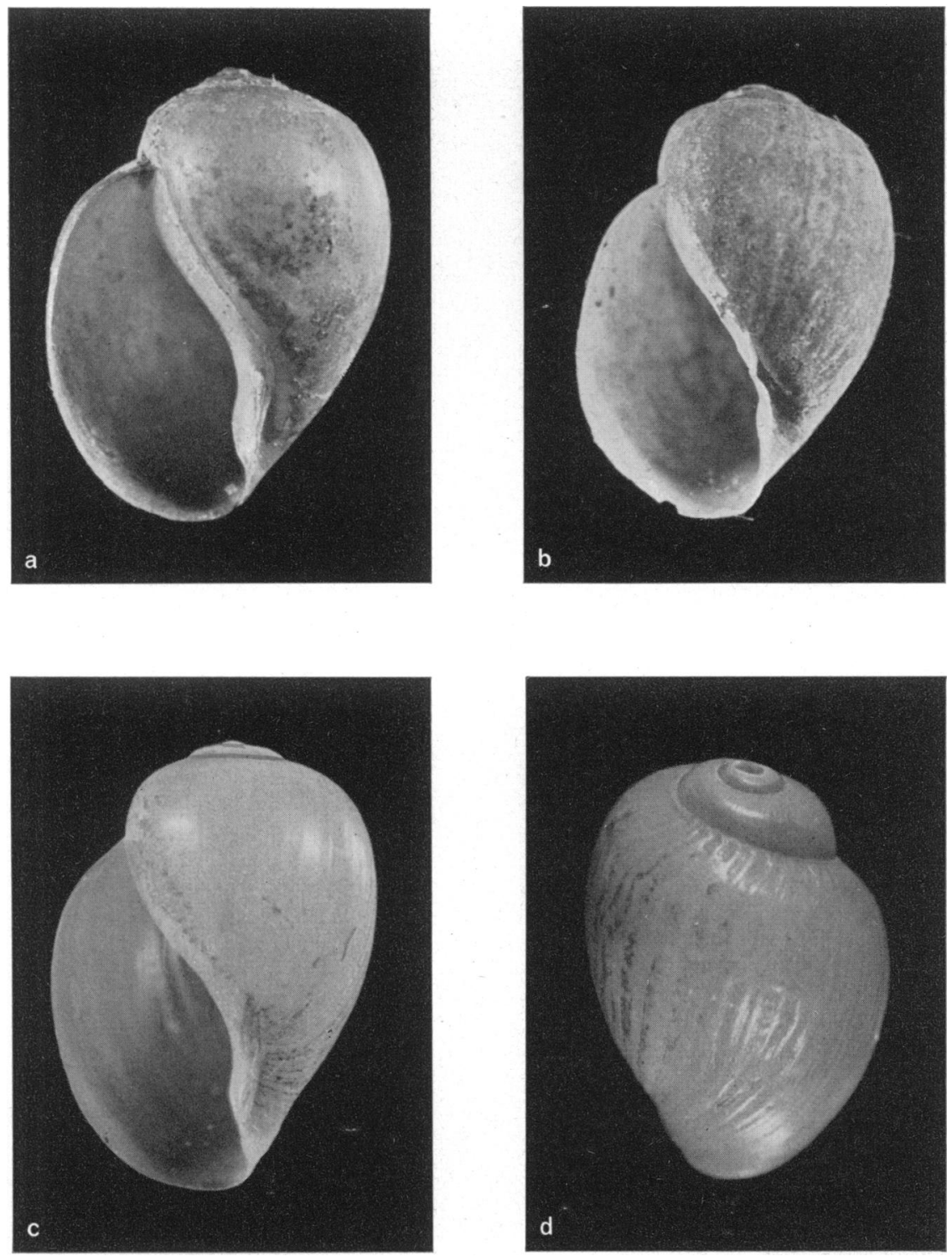

Fig. 5. B. globosus. $a=$ Sassa River, Angola, $15.1 \mathrm{~mm} ; \mathrm{b}=$ Bwambi, Uganda, $15.0 \mathrm{~mm}$ (= masakaensis Preston); c, d = Chozi River, Northern Rhodesia, $14.7 \mathrm{~mm}$ (= choziensis Preston) 

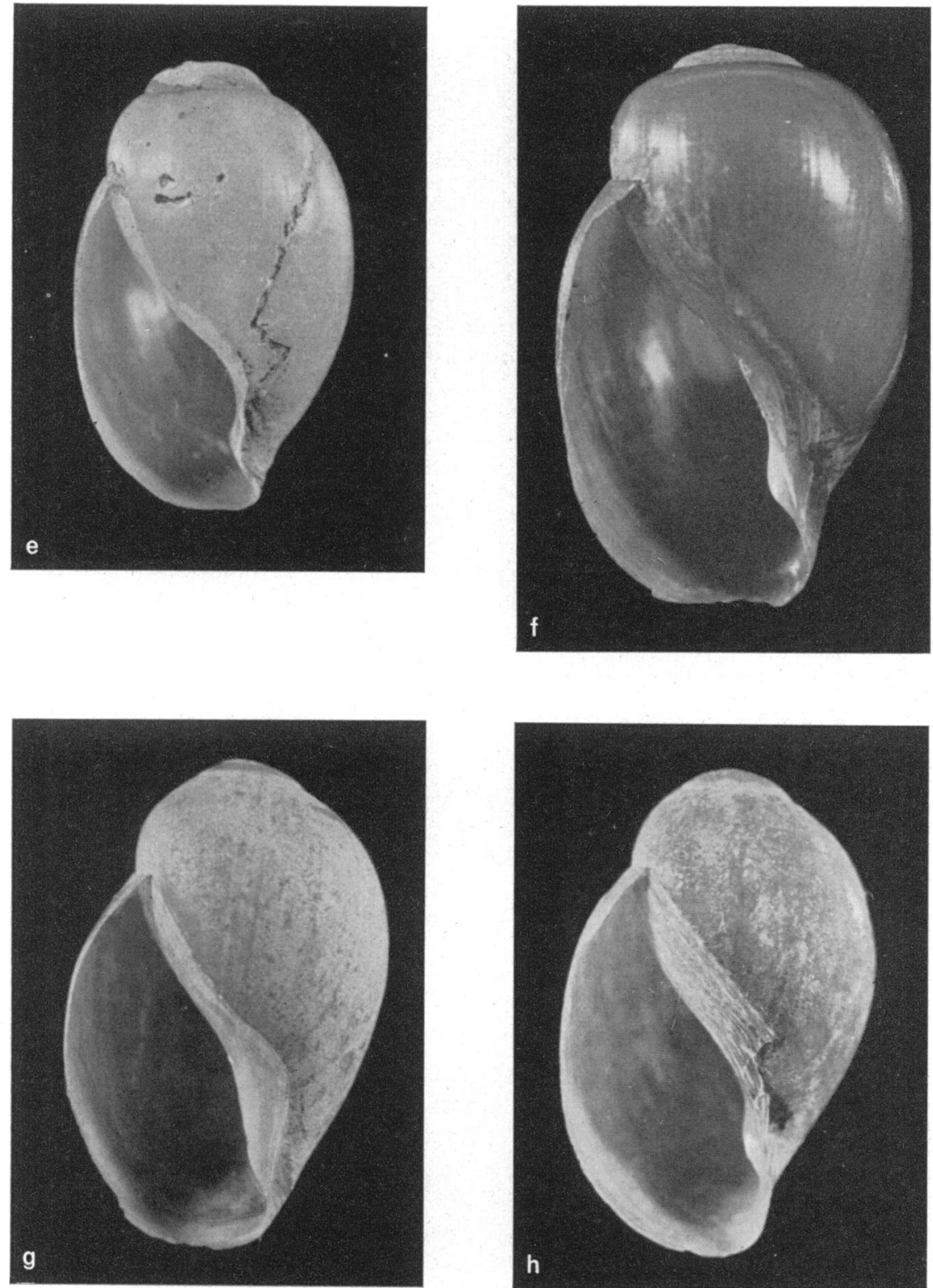

Fig. 5 (continued). B. globosus. e $=$ Zanzibar, $15.0 \mathrm{~mm} ; f=$ Lake Ngwasi, Tanganyika, $19.0 \mathrm{~mm} ; \mathrm{g}=$ Elisabethville, Belgian Congo, $16.6 \mathrm{~mm} ; \mathrm{h}=$ Sanoquelli, Liberia, $16.4 \mathrm{~mm}$ 


\section{PLATE VIII}
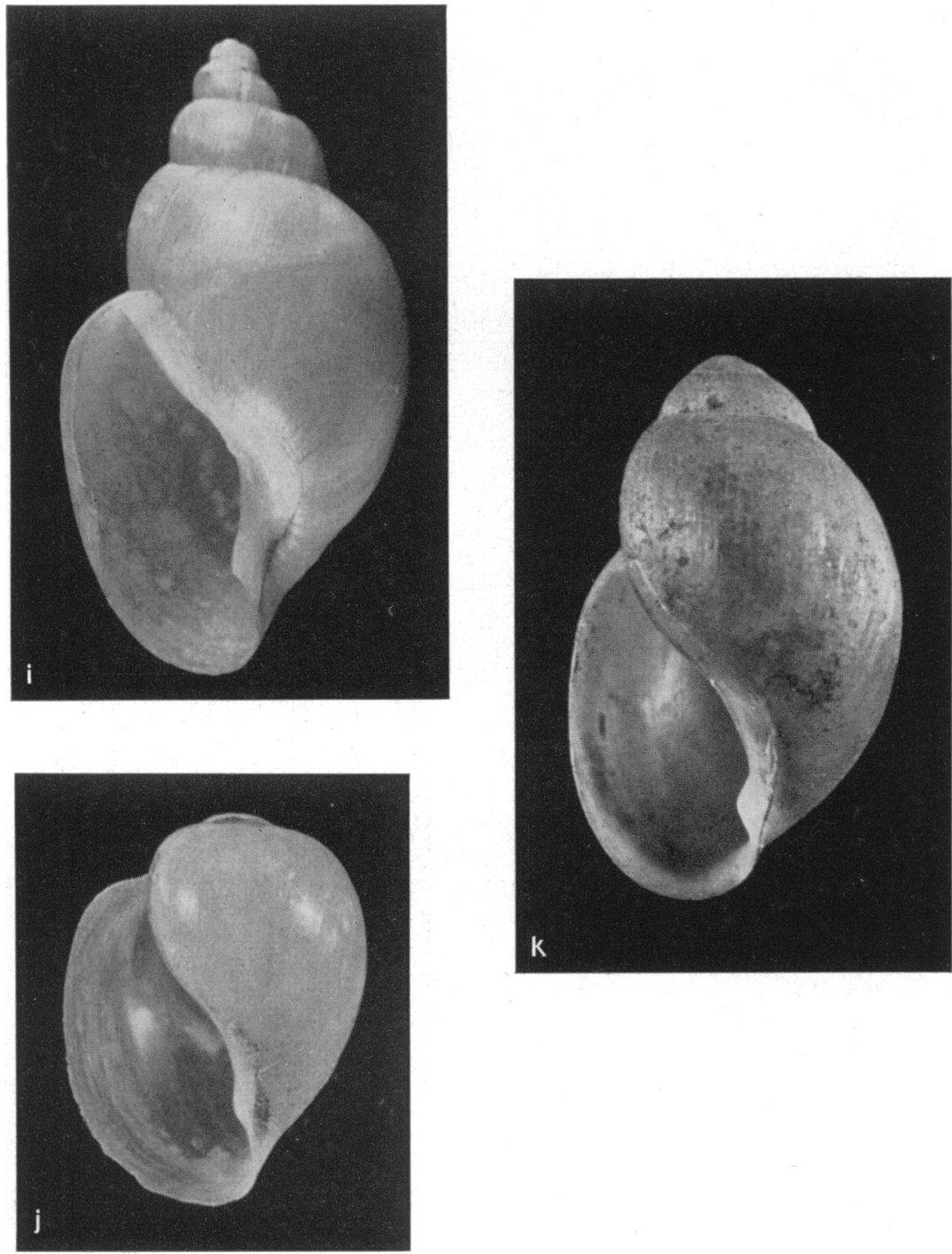

Fig. 5 (concluded). B. globosus. $\mathrm{i}=$ laboratory-bred, $19.2 \mathrm{~mm} ; \mathrm{j}=$ lagoon at Lake Nyasa, $12.0 \mathrm{~mm}$ (= karongensis Smith) ; $\mathrm{k}=$ Nigeria, $17.0 \mathrm{~mm}$ 
PLATE IX
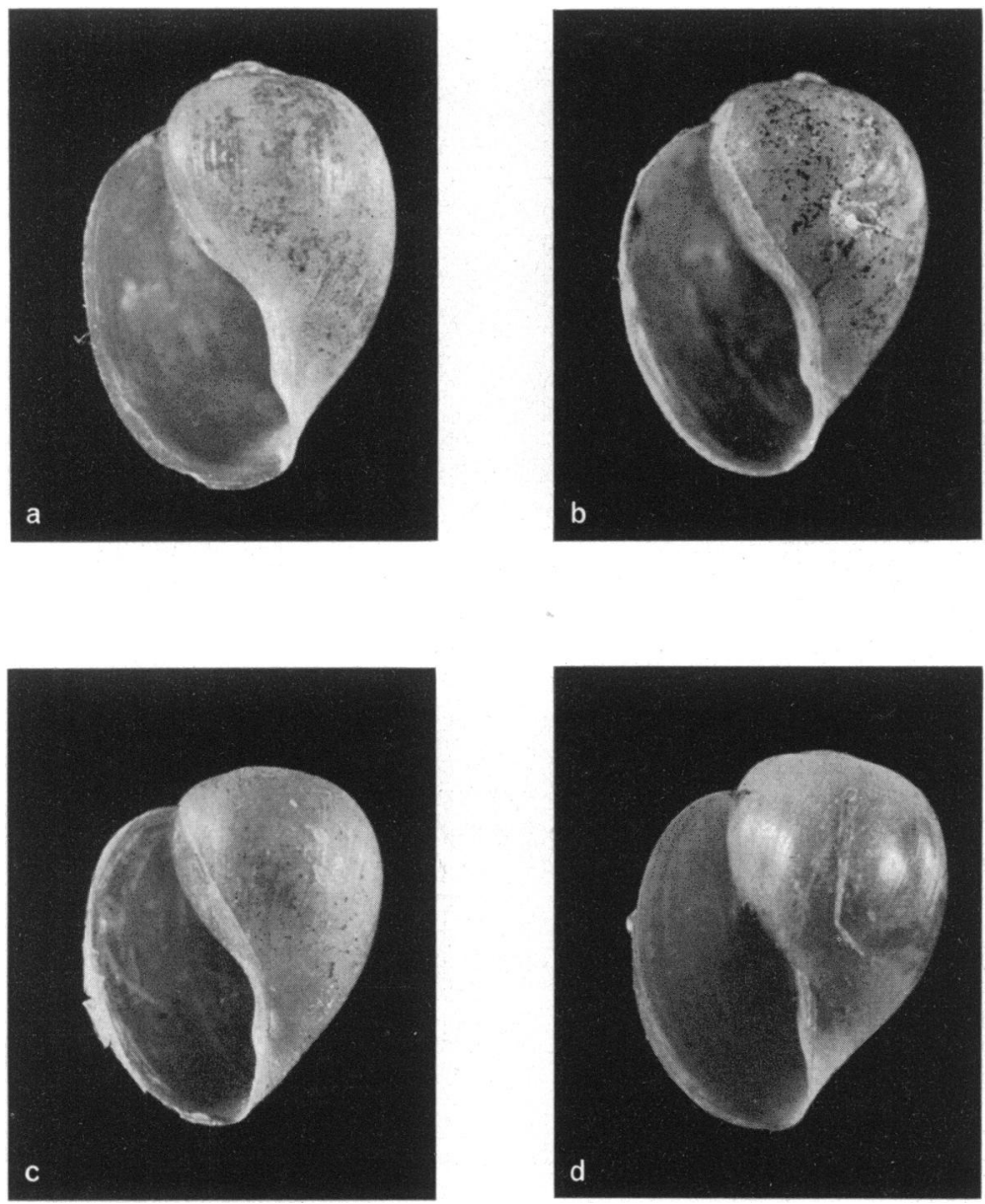

Fig. 6. B. jousseaumei. $\mathrm{a}=$ Casamance River, $10.1 \mathrm{~mm} ; \mathrm{b}, \mathrm{c}=$ Simoto Bolon, Gambia, $10.0 \mathrm{~mm}$ and $9.6 \mathrm{~mm} ; \mathrm{d}=$ Niger River at Firgoun, $9.9 \mathrm{~mm}$ 

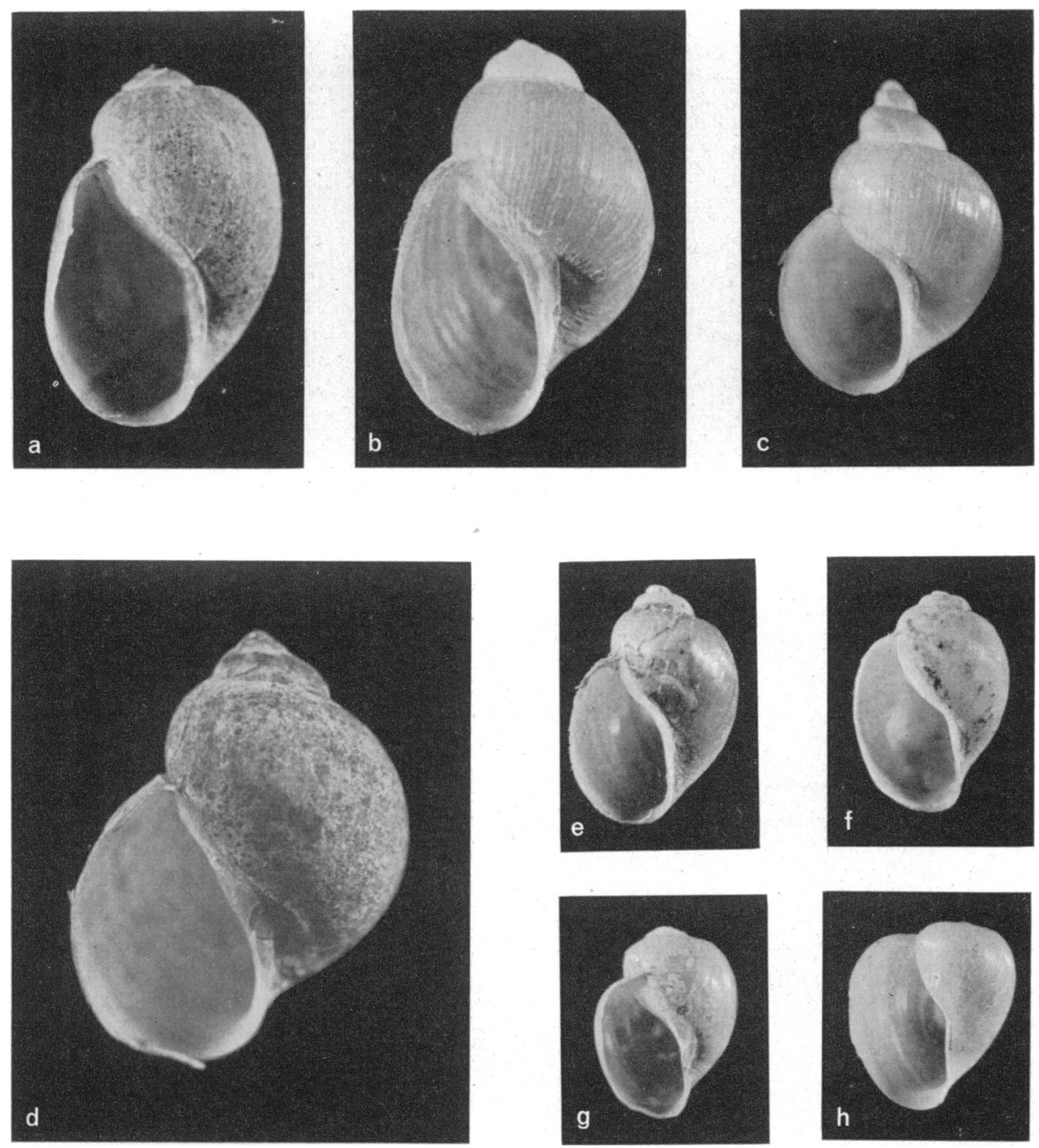

Fig. 7. B. tropicus tropicus. $a, b=$ Kapalonga Dam, near Lusaka, Northern Rhodesia, $11.2 \mathrm{~mm}$ and $12.0 \mathrm{~mm}$; $\mathrm{c}=$ Aapies River, Transvaal, $9.3 \mathrm{~mm}$; $\mathrm{d}=$ Salisbury, Southern Rhodesia, $13.1 \mathrm{~mm}$; e, $f=$ Litanda Stream, Northern Rhodesia, $7 \mathrm{~mm}$ (= corneus Morelet) $; \mathrm{g}, \mathrm{h}=$ Kalongana Stream, Mankoya, Northern Rhodesia, $6 \mathrm{~mm}(\mathrm{~h}=$ depressus Haas) 
PLATE XI
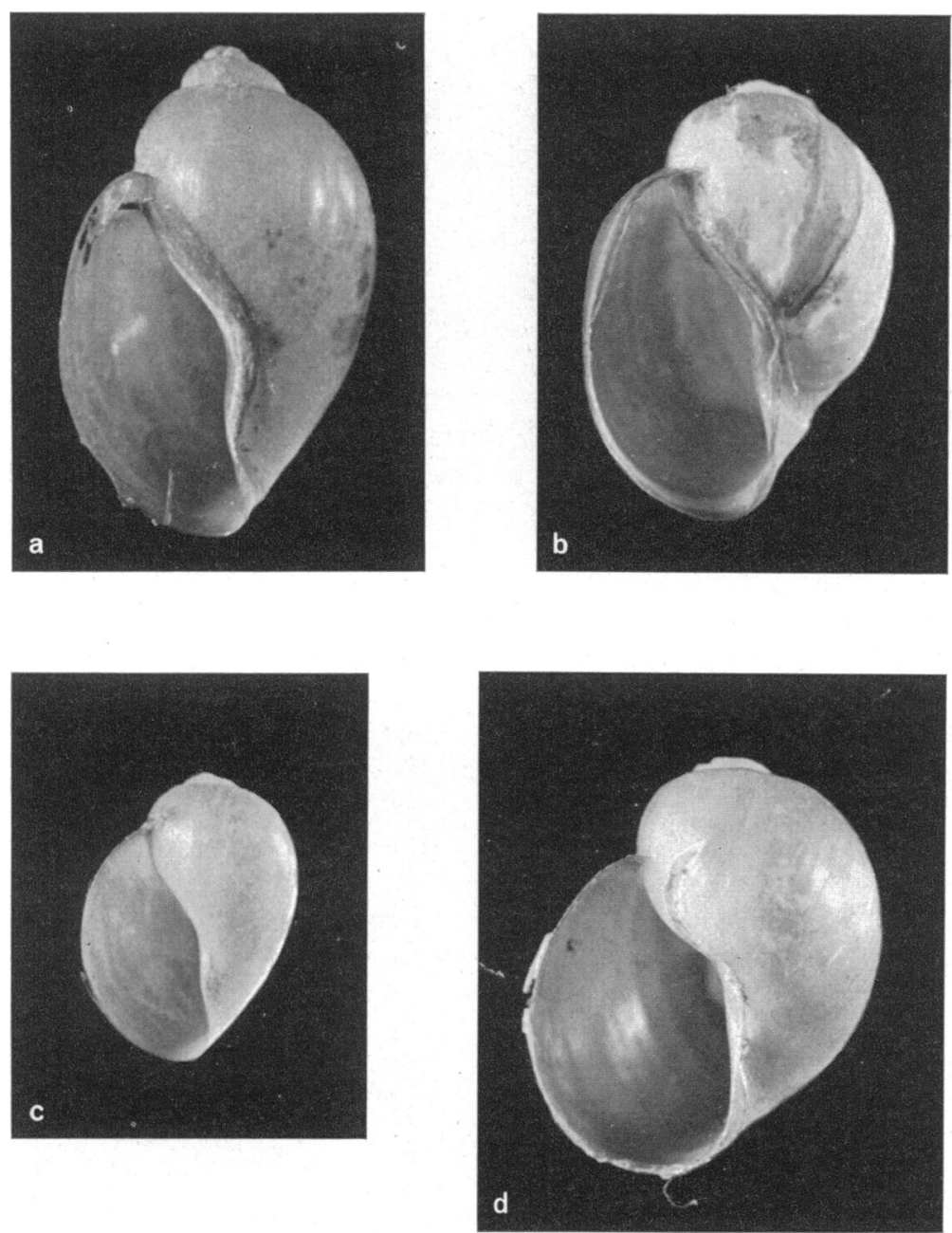

Fig. 8. B. tropicus angolensis. $a, b=$ Lufinda, Angola, $13.3 \mathrm{~mm}$ and $12.3 \mathrm{~mm} ; \mathrm{c}=$ Cafunda Cavilongo, Angola, $8.2 \mathrm{~mm} ; \mathrm{d}=$ Swakibula, Belgian Congo, $11.5 \mathrm{~mm}$ 
PLATE XII
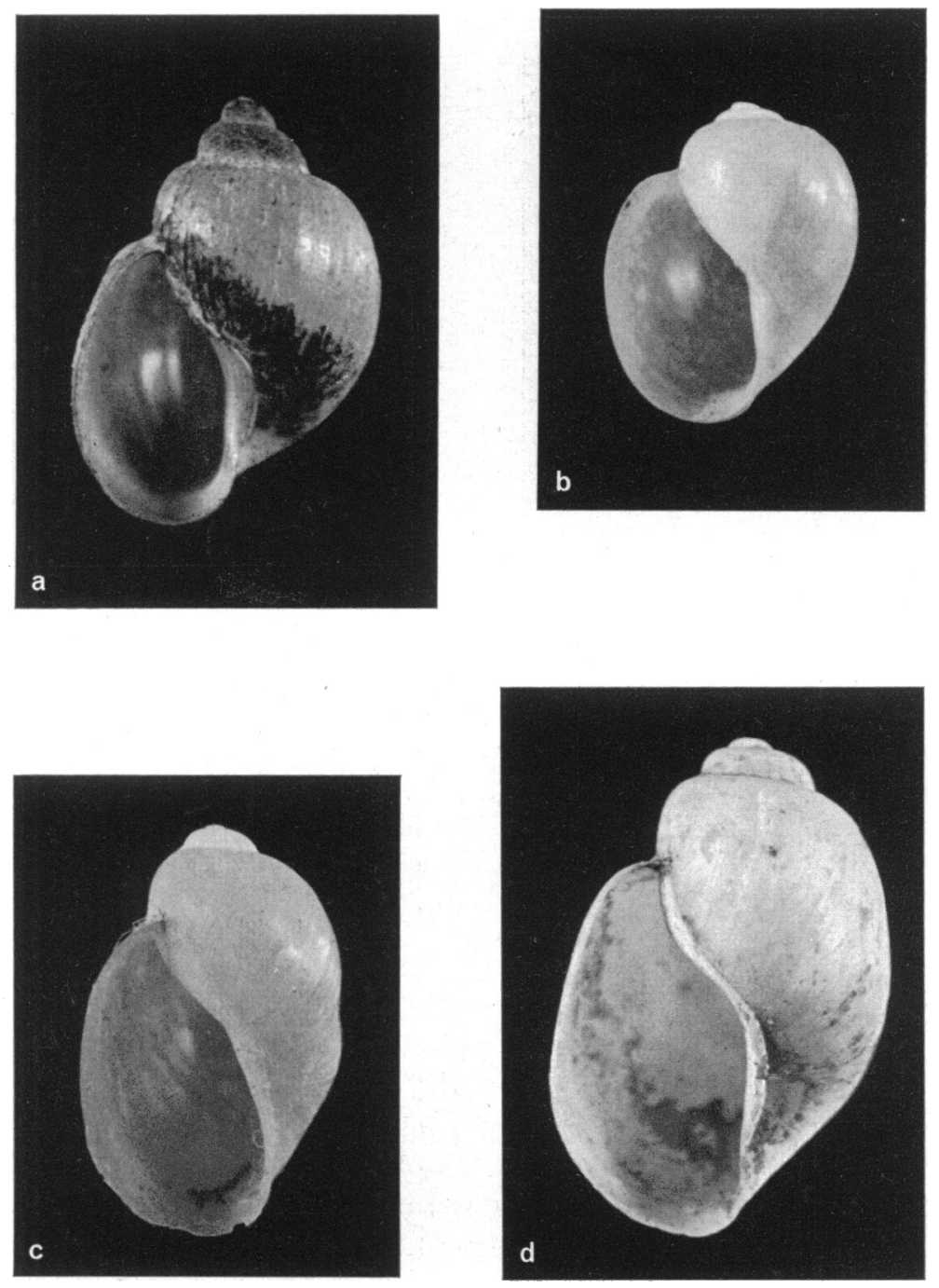

Fig. 9. B. tropicus zanzebaricus. $a=$ Ngudu, Tanganyika, $12.0 \mathrm{~mm}$; b = Lake Jipe, Tanganyika, $9.2 \mathrm{~mm}$; $\mathbf{c}=$ Elisabethville, Belgian Congo, $11.3 \mathrm{~mm} ; \mathrm{d}=$ Malya, Tanganyika, $13.6 \mathrm{~mm}$ 
PLATE XIII
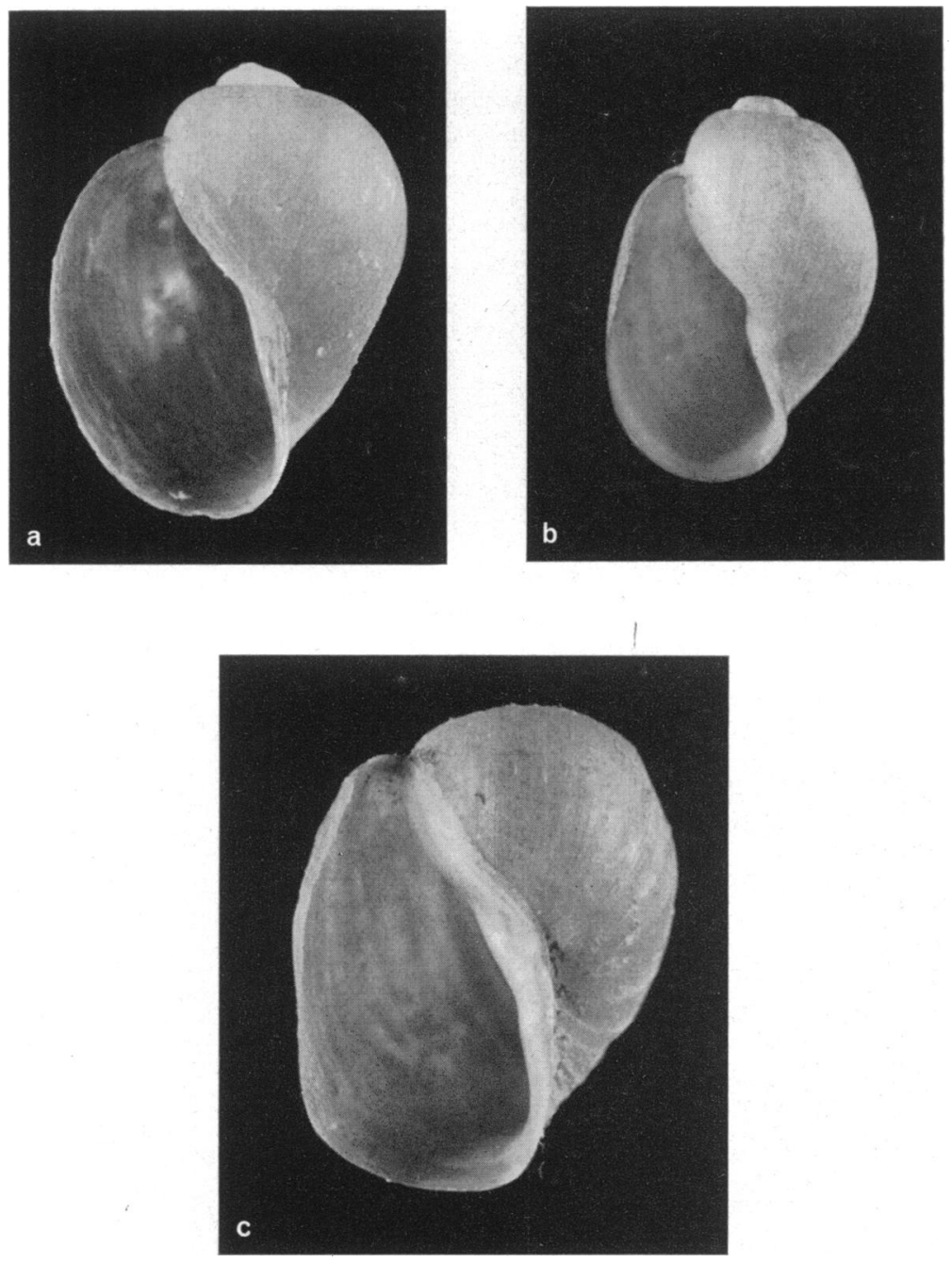

Fig. 10. B. tropicus mutandaensis. a = Fort Portal Crater Lake, Uganda, $12.1 \mathrm{~mm} ; \mathrm{b}=$ Lake Mutanda, Uganda, $10.6 \mathrm{~mm} ; \mathrm{c}=$ Kichwamba Crater Lake, Uganda, $13.2 \mathrm{~mm}$ 


\section{PLATE XIV}
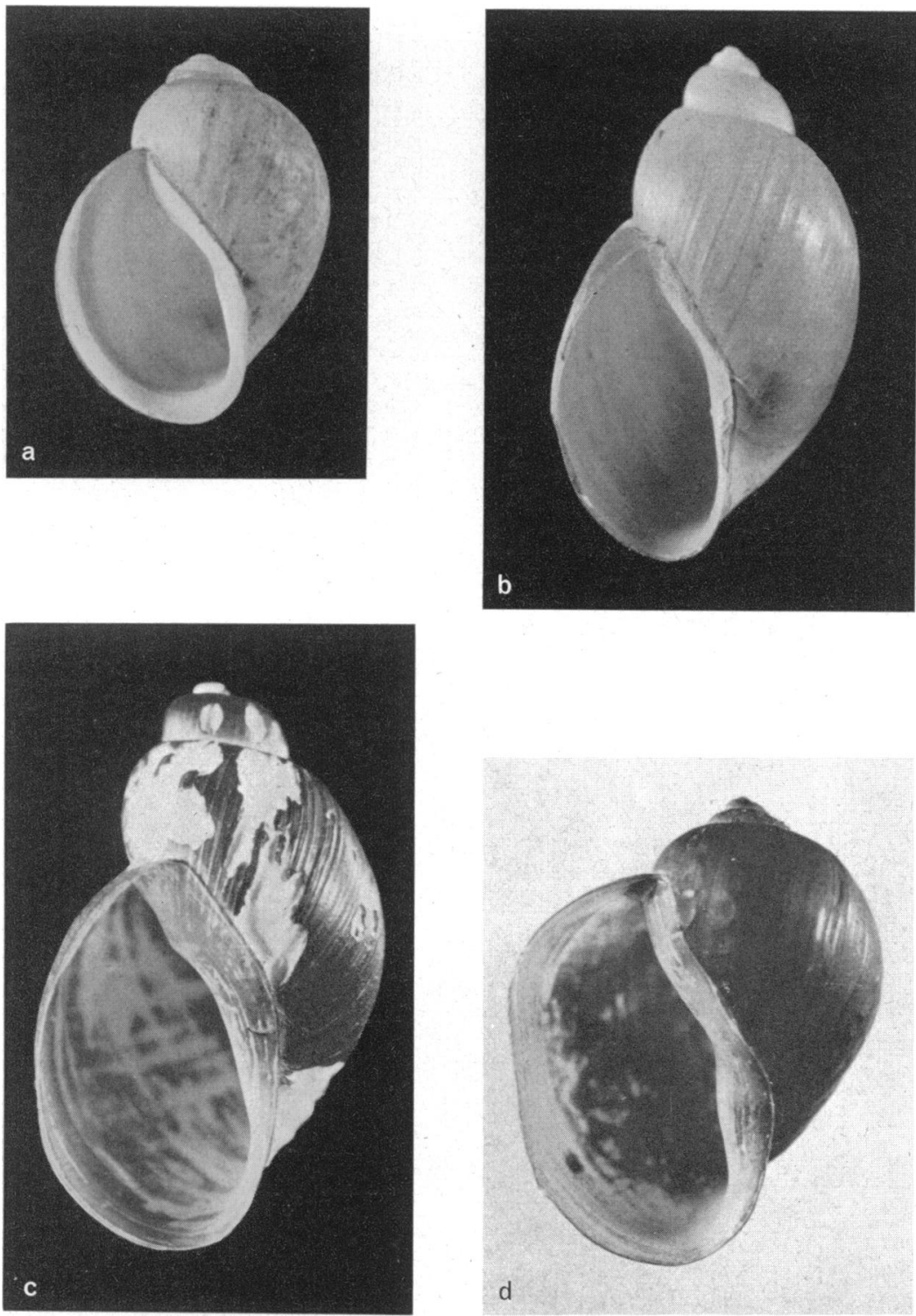

Fig. 11. B. tropicus alluaudi. $\mathrm{a}=$ Nairobi River, Kenya, $11.2 \mathrm{~mm}$ (= typ. alluaudi); $\mathrm{b}=\mathrm{Ol}$ Joro Orok, Kenya, $15.2 \mathrm{~mm}$ (= permembranacea Preston) ; $\mathrm{c}=$ Lake Naivasha, Kenya, 17.1 mm (= syngenes Preston); $\mathrm{d}=$ near Athi River, Kenya, $14.1 \mathrm{~mm}$ 
PLATE XV
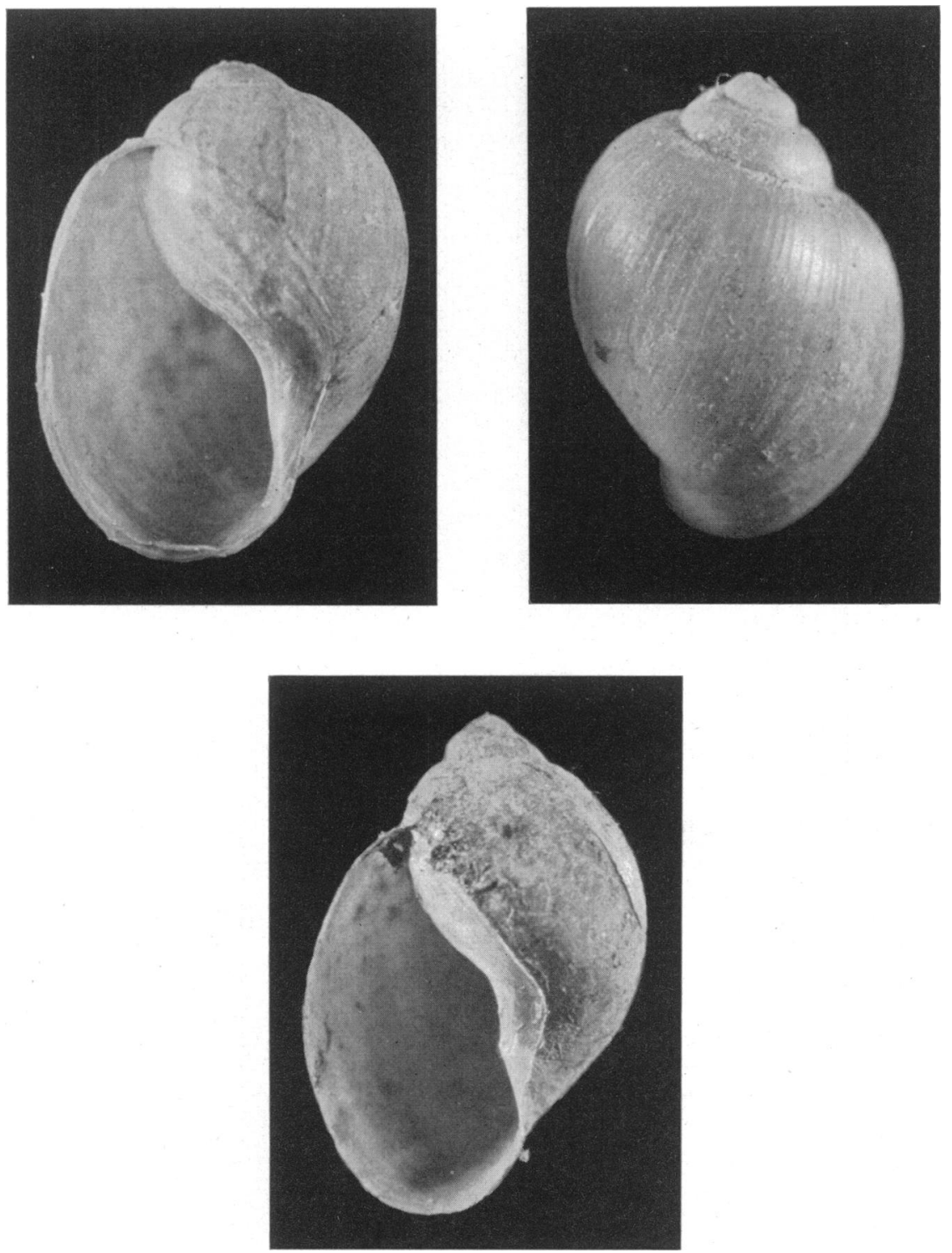

Fig. 12. B. liratus, Ambositra, Madagascar, $15.6 \mathrm{~mm}$ 
PLATE XVI
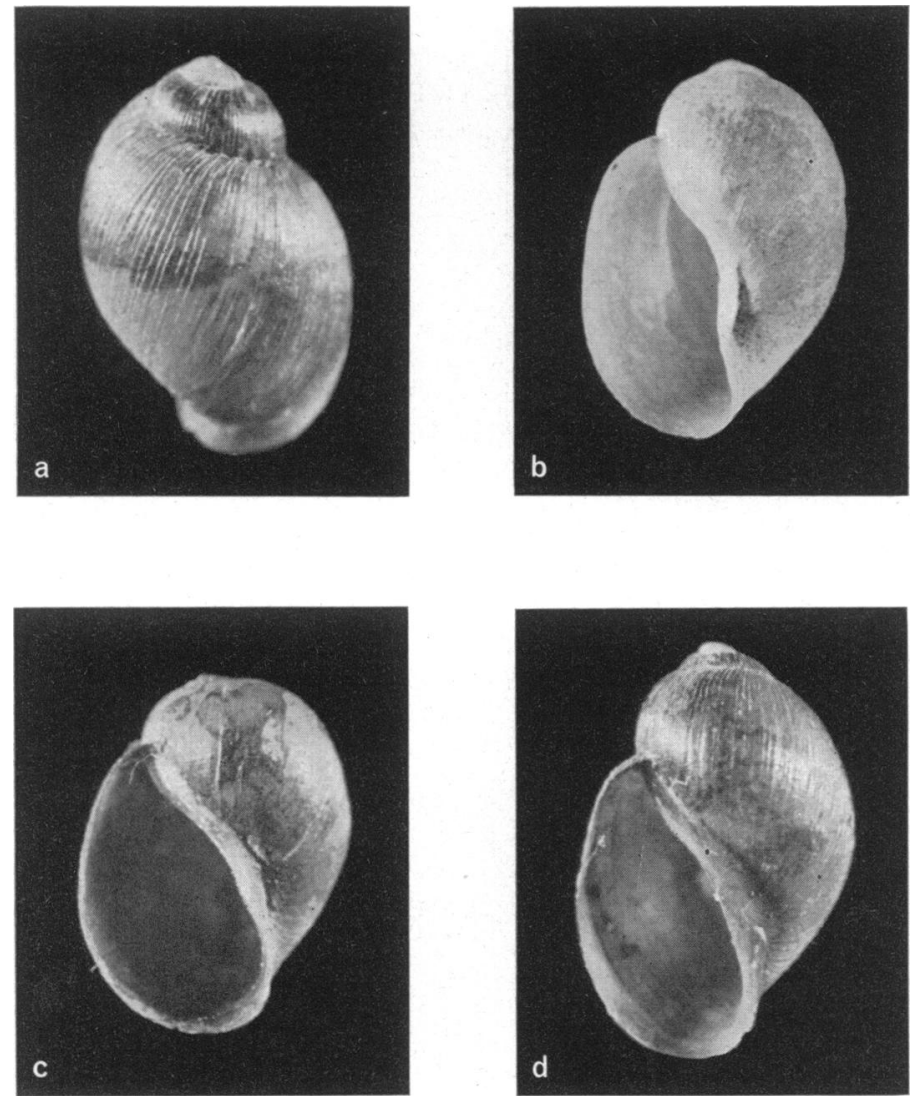

Fig. 13. B. sericinus. $a=$ pond near Lake Aramya, Ethiopia, $9.9 \mathrm{~mm} ; \mathrm{b}=$ between Aduwa and Adigrat, Eritrea, $9.6 \mathrm{~mm} ; \mathrm{c}=$ Bishoftu, Ethiopia, $9.4 \mathrm{~mm}$; d = pond near Lake Aramya, Ethiopia, $9.9 \mathrm{~mm}$ 

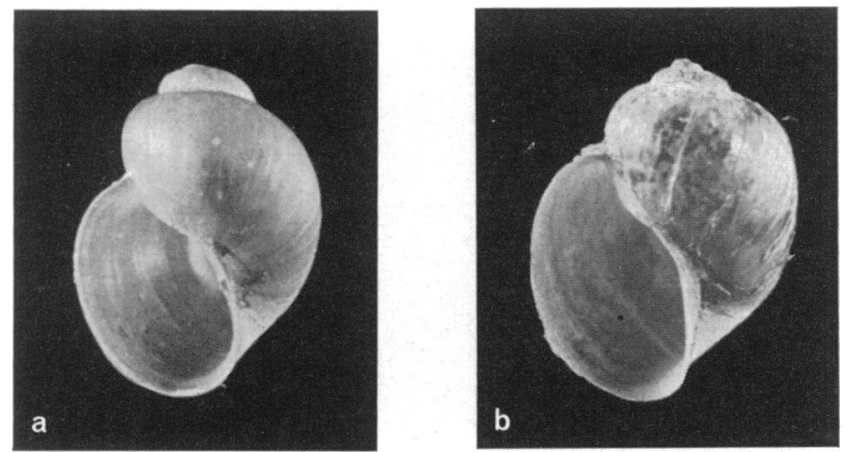

Fig. 14. B. guernei. a $=$ Kumbidja Bolon, Gambia, $8.2 \mathrm{~mm}$; $\mathrm{b}=$ Niger River at Firgoun, $8.7 \mathrm{~mm}$
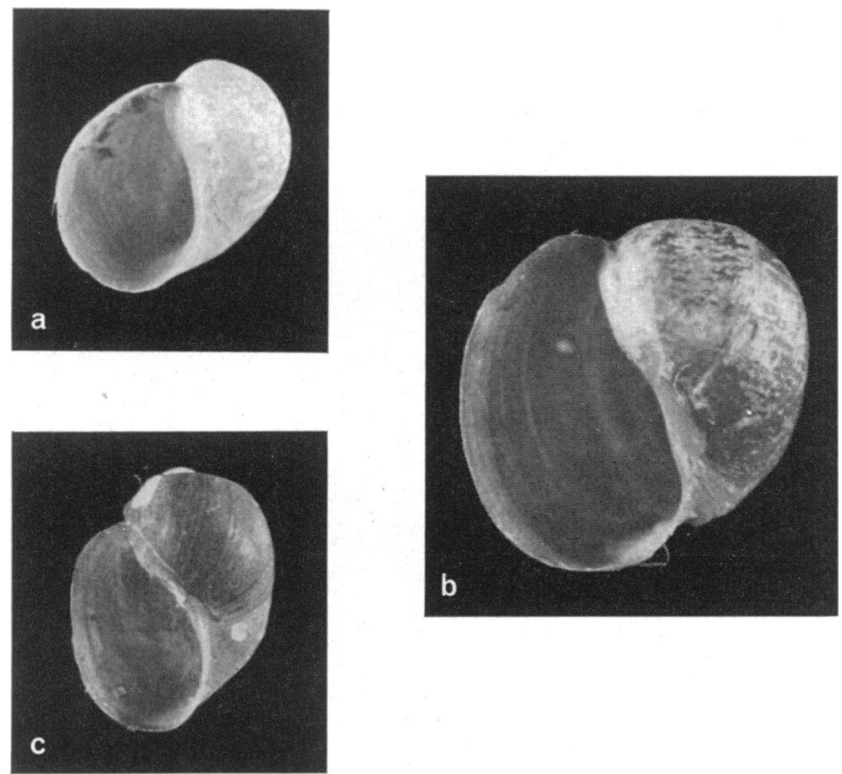

Fig. 15. B. transversalis. a = Buvuma Channel, Lake Victoria, $7.0 \mathrm{~mm} ; b, c=$ Jinja Bay, Lake Victoria, $7.6 \mathrm{~mm}$ and $6.9 \mathrm{~mm}$ 

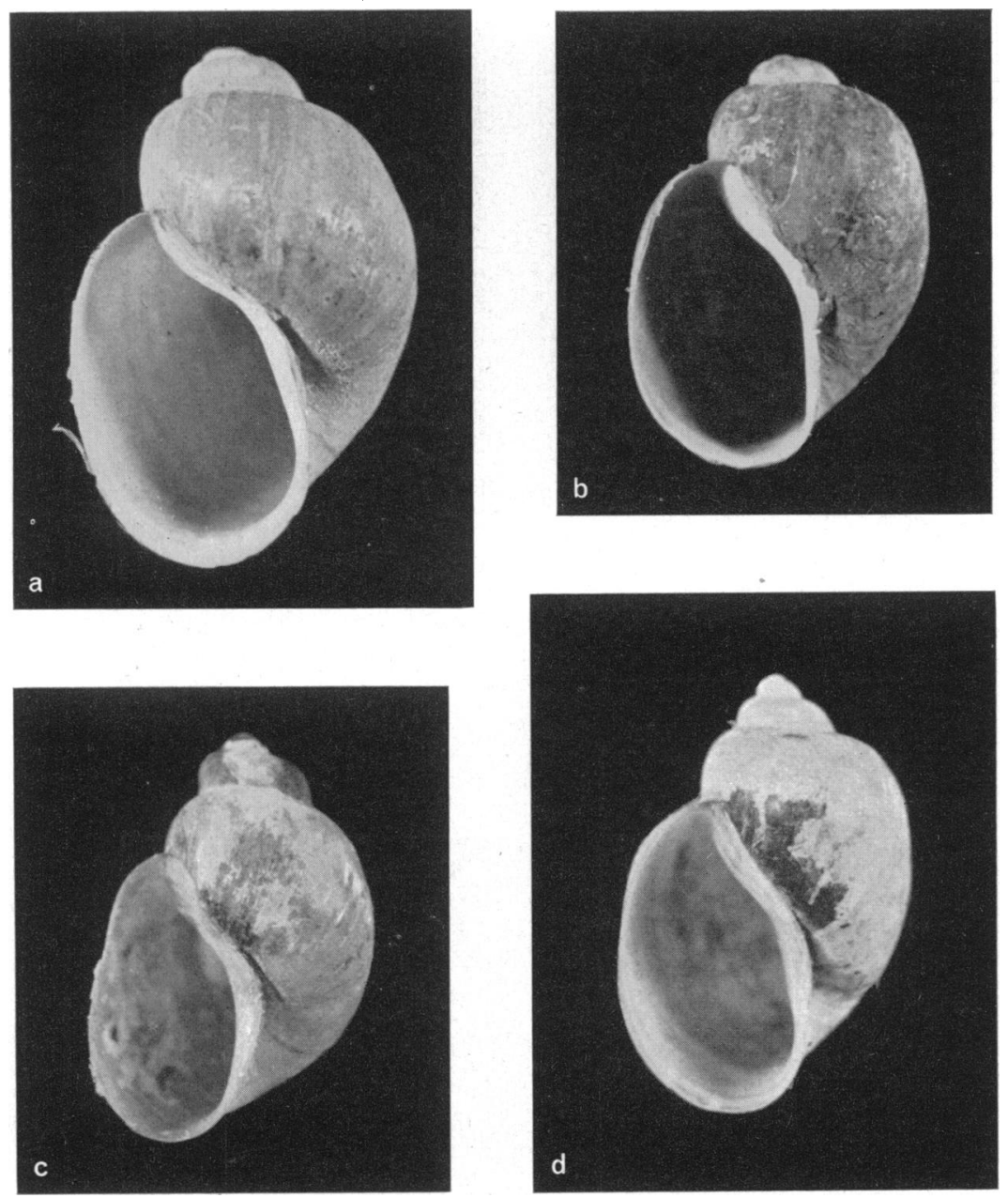

Fig. 16. B. truncatus truncatus. $\mathrm{a}, \mathrm{b}=$ Gehabliya Canal, Menufiya, Egypt, $14.8 \mathrm{~mm}$ and $11.3 \mathrm{~mm} ; \mathrm{c}, \mathrm{d}=$ Stream in Matariya area, Egypt, $11.4 \mathrm{~mm}$ and $11.7 \mathrm{~mm}$ 

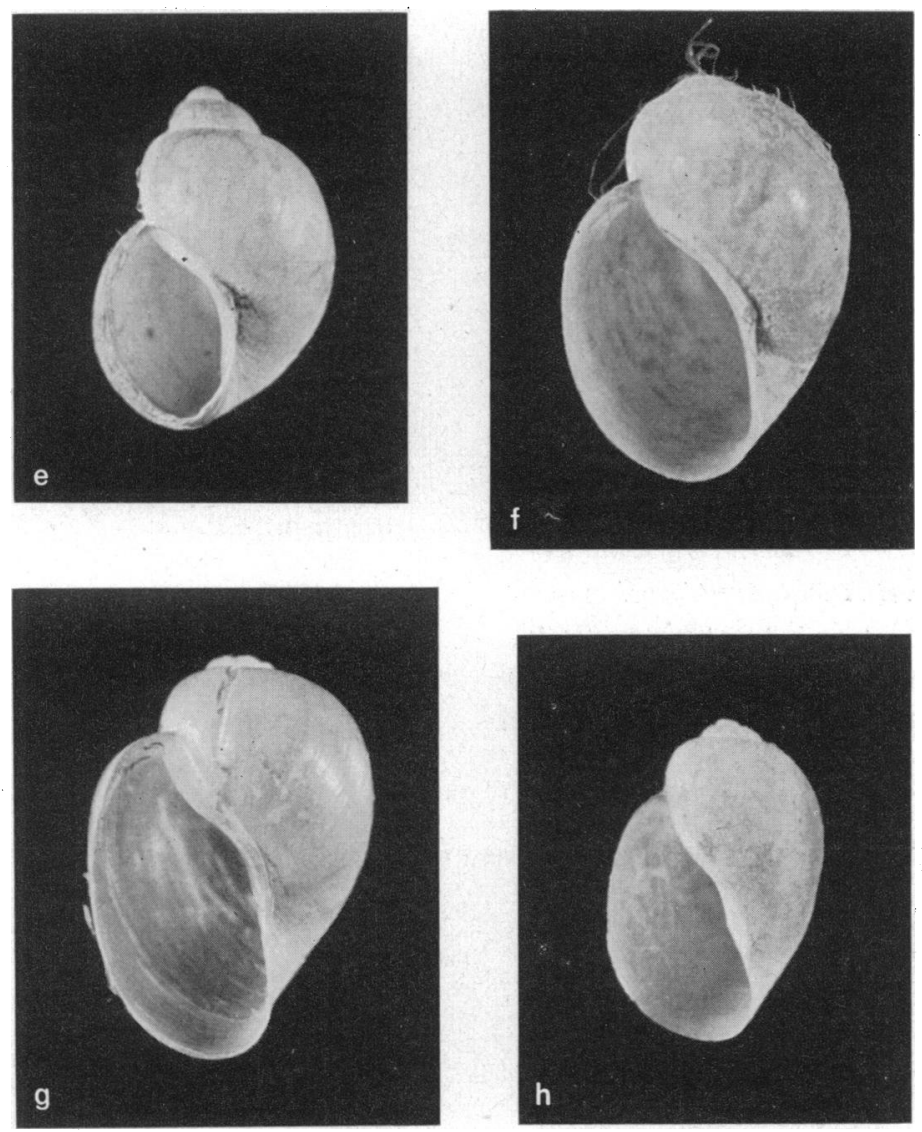

Fig. 16 (concluded). B. truncatus truncatus. $\mathrm{e}={ }^{\prime}$ Eneiba, Nubia, $9.0 \mathrm{~mm} ; \mathrm{f}=$ Iskanderun Drain, Qalyubiya, Egypt, $10.2 \mathrm{~mm} ; \mathrm{g}=$ Buyende, Uganda, $10.8 \mathrm{~mm} ; \mathrm{h}=$ Wad Medani, Sudan, $8.4 \mathrm{~mm}$ 


\section{PLATE XX}
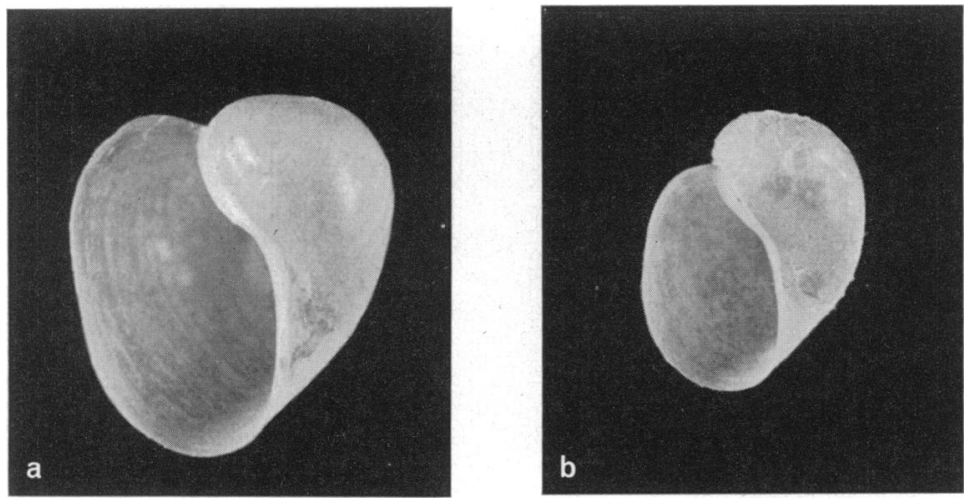

Fig. 17. B. truncatus trigonus. $a=$ Entebbe, Uganda, $9.2 \mathrm{~mm} ; b=$ Dagusi Island, Lake Victoria, $7.1 \mathrm{~mm}$ (= strigosus Martens)
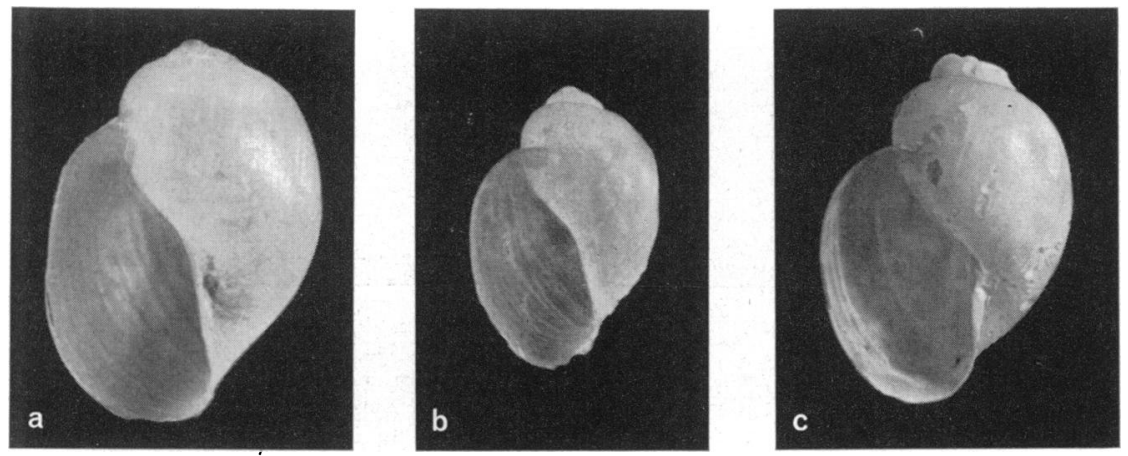

Fig. 18. B. truncatus rohlfsi. $a=$ Jebel Marra, Darfur, $9.9 \mathrm{~mm} ; \mathrm{b}=$ Lake Barombi Kotto, British Cameroons, $7.3 \mathrm{~mm}$; c = Dawa, Ghana, $9.0 \mathrm{~mm}$ 
PLATE XXI
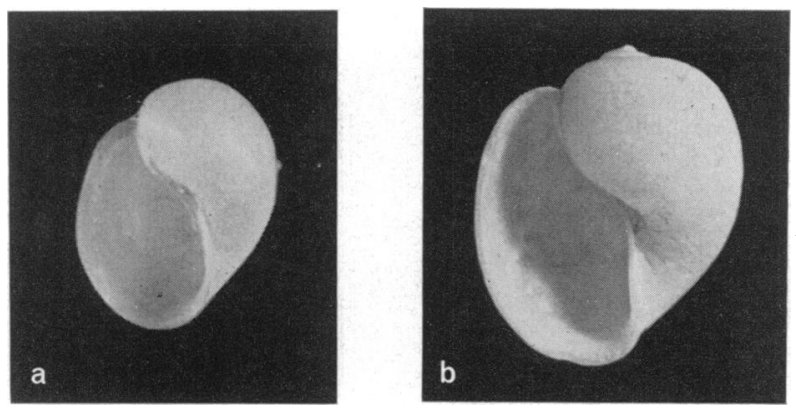

Fig. 19. B. nyassanus. Nkata Bay, Lake Nyasa, $5.0 \mathrm{~mm}$ and $6.4 \mathrm{~mm}(\mathrm{a}=$ succinoides Smith)
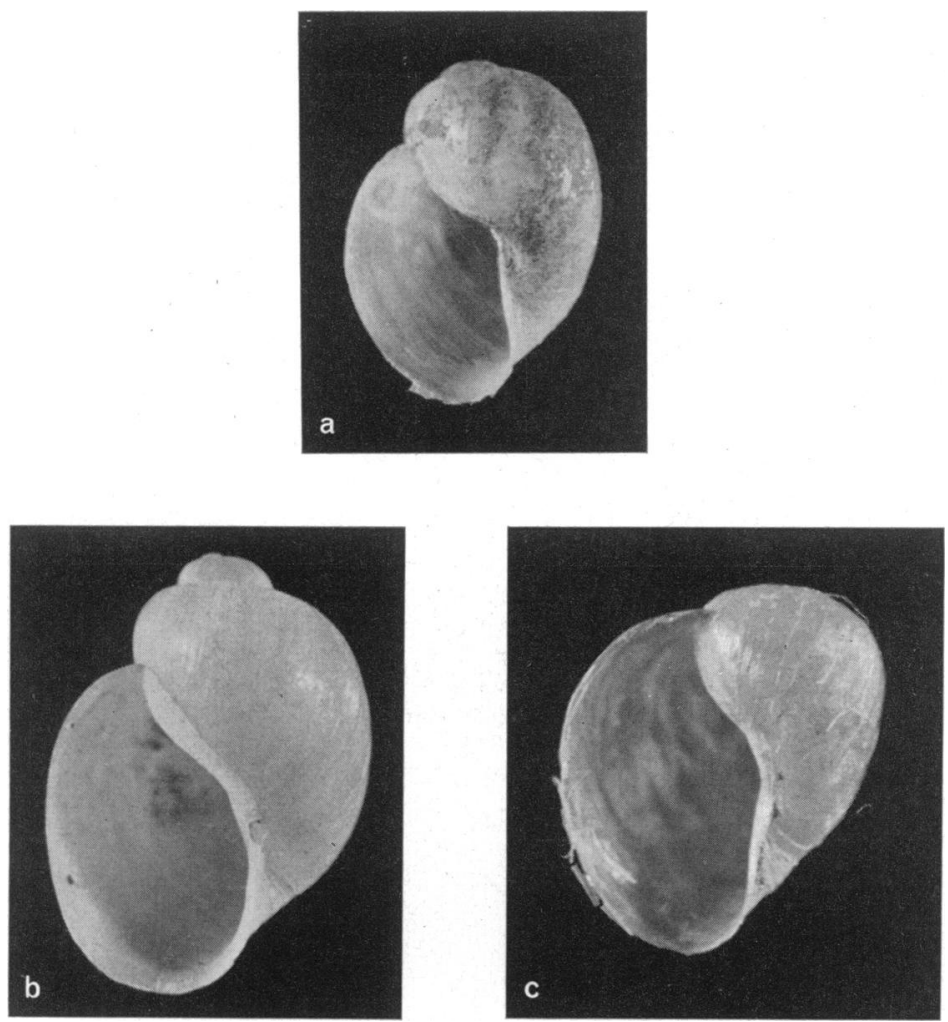

Fig. 20. B. coulboisi. $\mathrm{a}=$ Albertville, Lake Tanganyika, $9.1 \mathrm{~mm} ; \mathrm{b}=$ Butiaba, Lake Albert, $11.1 \mathrm{~mm}$; $\mathrm{c}=$ Lake Kirwa, Belgian Congo, $9.5 \mathrm{~mm}$

$$
-61-
$$



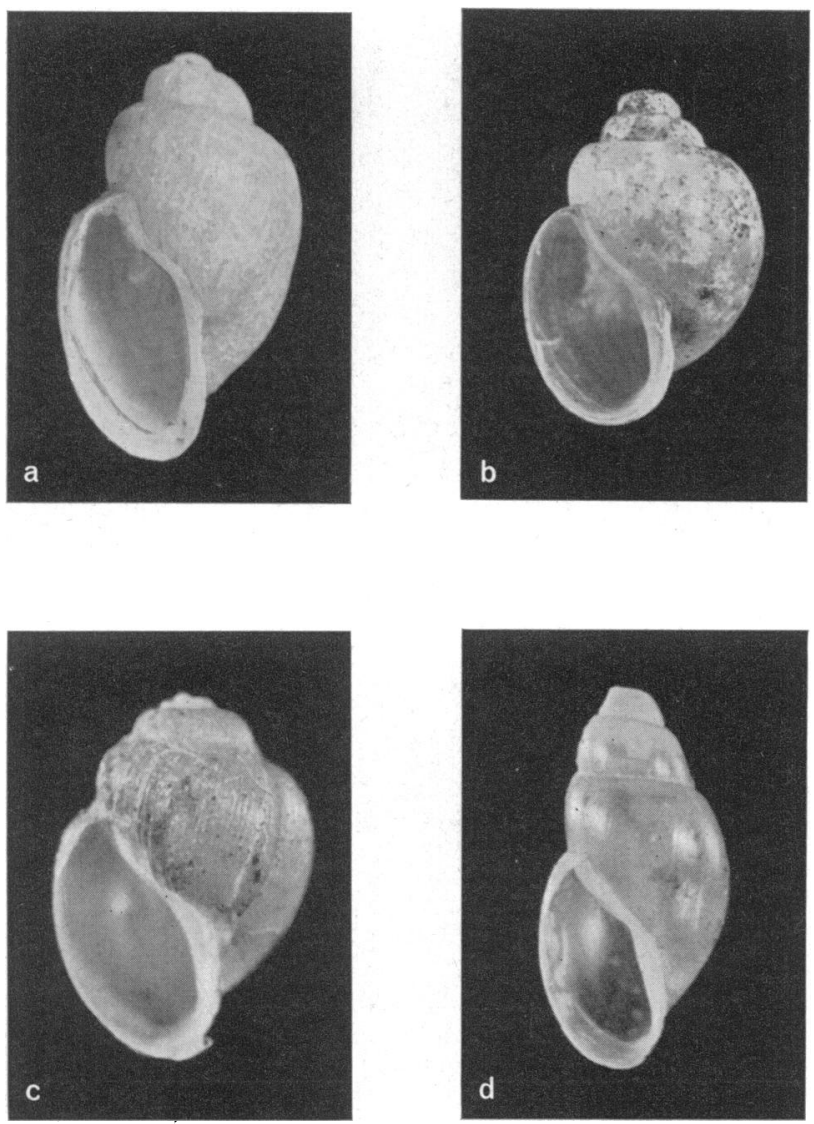

Fig. 21. B. camerunensis, Lake Barombi Kotto, British Cameroons, $6.2 \mathrm{~mm}$; b $=B$. reticulatus, Kisumu, Kenya, $4.5 \mathrm{~mm} ; \mathrm{c}=$ B. reticulatus, immature specimen, Mazabuka, Northern Rhodesia, $3.0 \mathrm{~mm} ; \mathrm{d}=B$. cernicus, Mauritius, $5.1 \mathrm{~mm}$ 

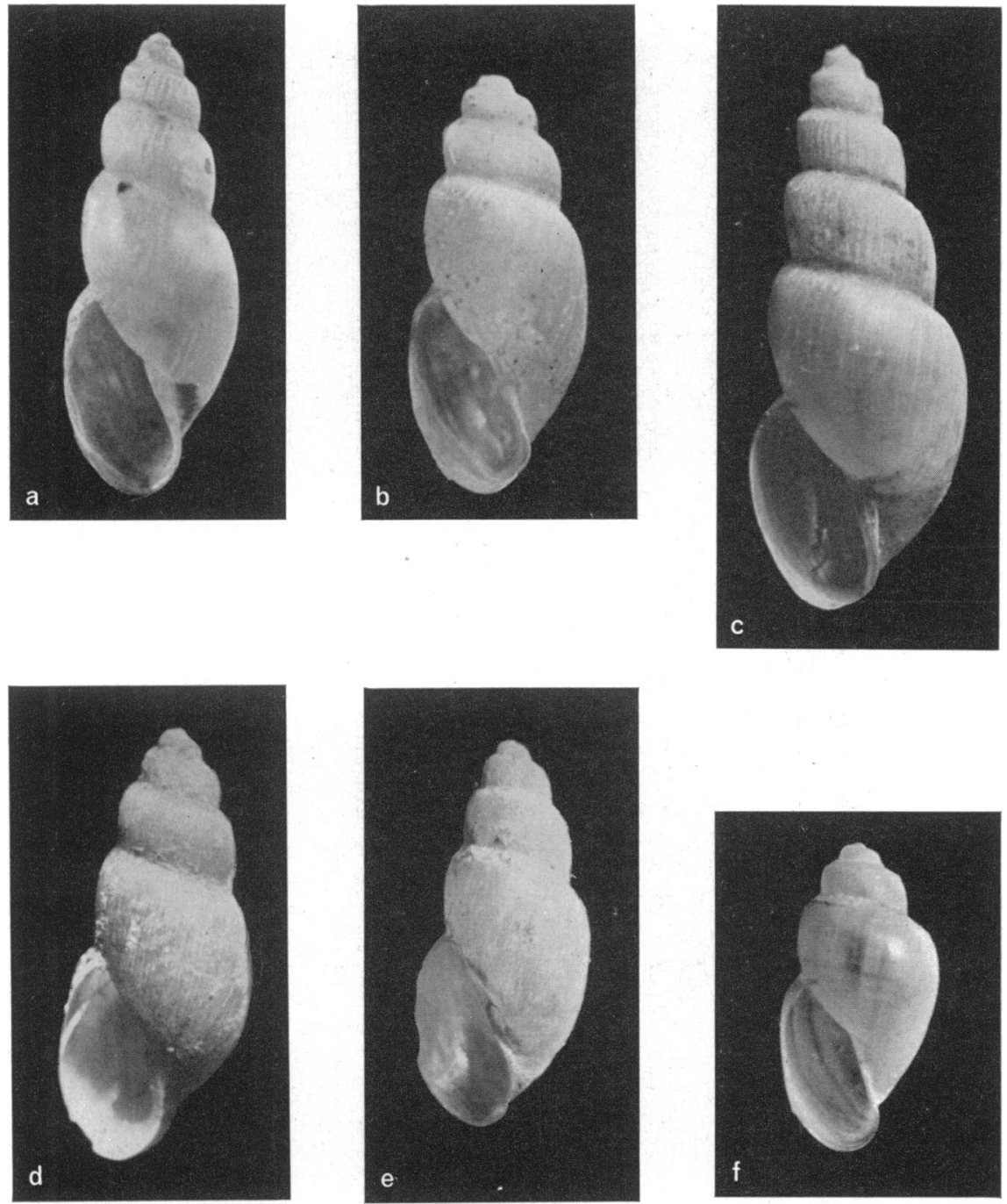

Fig. 22. B. forskalii. $a=$ Runda School, Kisumu, Kenya, $9.0 \mathrm{~mm}$; b = Bangata River, Belgian Congo, $8.4 \mathrm{~mm} ; \mathrm{c}=$ Camana, Angola, $11.1 \mathrm{~mm} ; \mathrm{d}=$ Ankaratra, Madagascar, $8.8 \mathrm{~mm}$; $\mathrm{e}=$ Qalama, Egypt, $7.4 \mathrm{~mm} ; \mathrm{f}=$ Bugungu, Uganda, $4.9 \mathrm{~mm}$ 

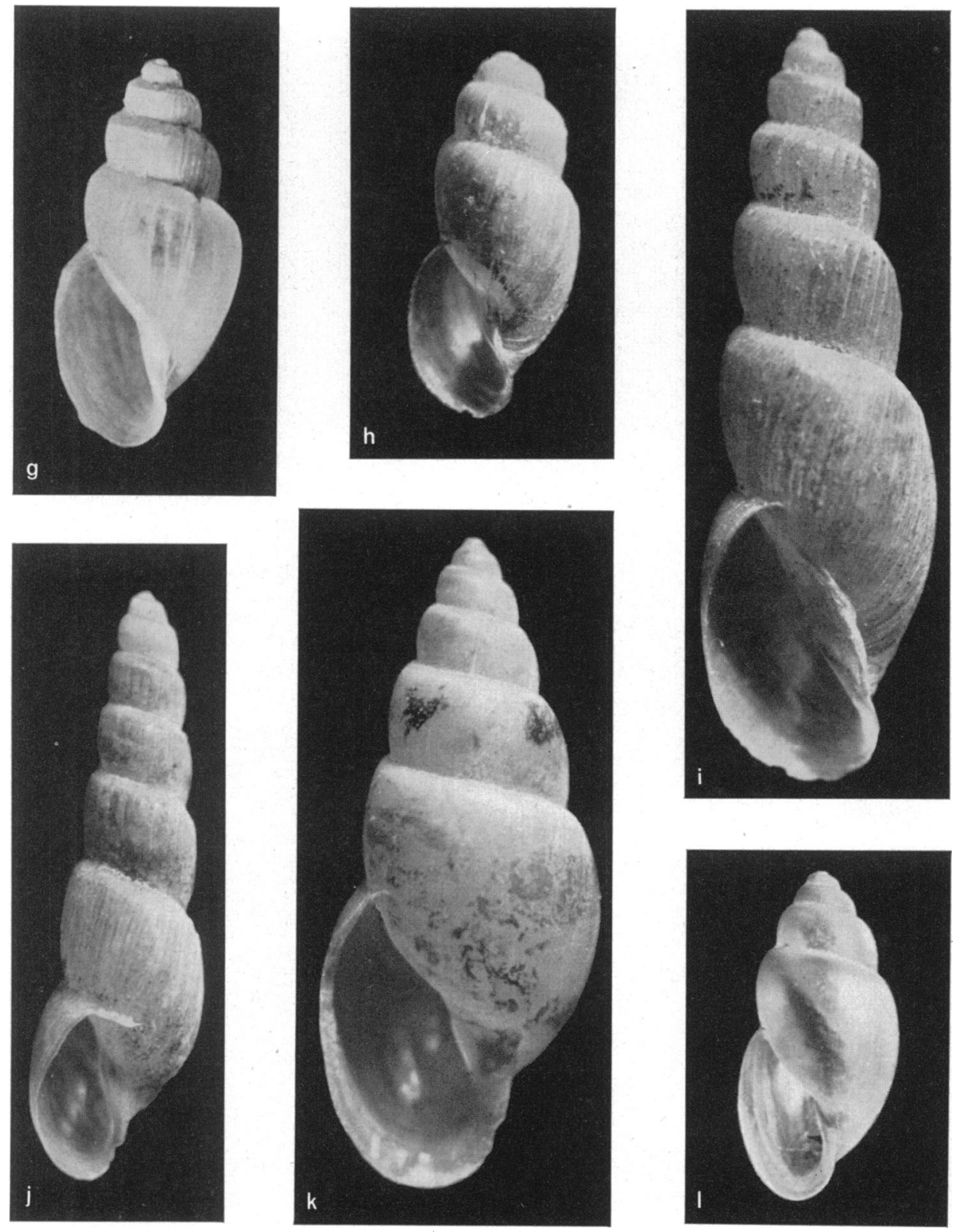

Fig. 22 (concluded). B. forskalii. $\mathrm{g}=$ Boma, Belgian Congo, $8.5 \mathrm{~mm} ; \mathrm{h}=$ Kiti Bridge, Gambia, $8.2 \mathrm{~mm}$ (= dautzenbergi Germain) ; $i=$ Kimpese, Belgian Congo, $17.0 \mathrm{~mm} ; \mathrm{j}=$ Kosti, Sudan, $13.3 \mathrm{~mm} ; \mathrm{k}, \mathrm{l}=$ Lochinwar, Northern Rhodesia, $14.6 \mathrm{~mm}$ and $7.3 \mathrm{~mm}$ (= canescens Morelet) 

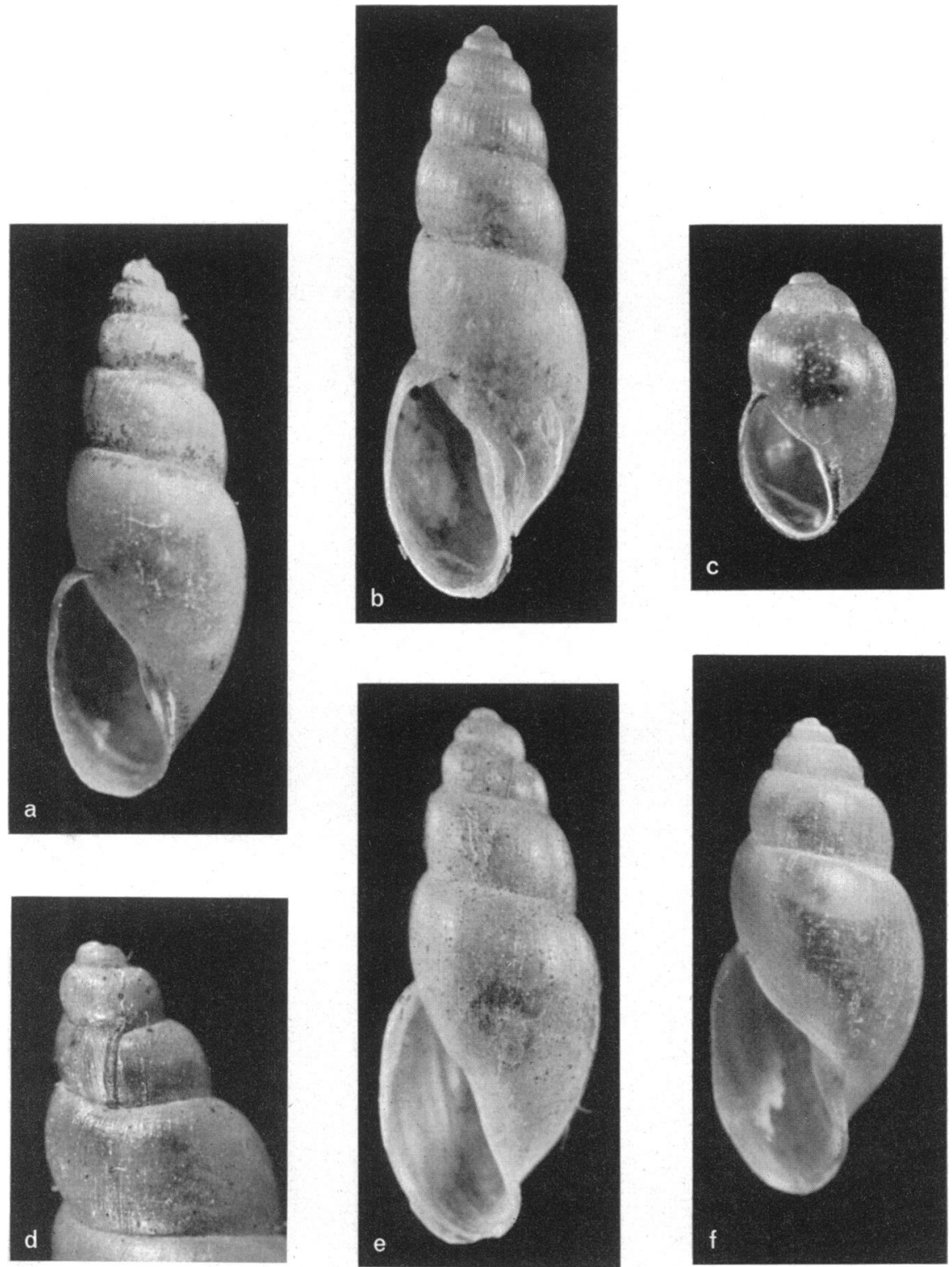

Fig. 23. $\mathrm{a}=$ B. scalaris, Kisumu, Kenya, $11.1 \mathrm{~mm} ; \mathrm{b}=$ B. scalaris, Lira, Uganda, $11.8 \mathrm{~mm} ; \mathrm{c}=B$. senegalensis, immature specimen, corresponding to the type, Sanchabari Pool, Gambia, $2.4 \mathrm{~mm} ; \mathrm{d}=B$. senegalensis, top of an adult to show peristome of the juvenile : $\mathrm{e}=B$. senegalensis, Sara Njobo Pool, Gambia, $10.7 \mathrm{~mm} ; f=B$. senegalensis, Sanchabari Pool, Gambia, $9.8 \mathrm{~mm}$ 